NBER WORKING PAPER SERIES

\title{
HISTORICAL LEGACIES AND AFRICAN DEVELOPMENT
}

\author{
Stelios Michalopoulos \\ Elias Papaioannou \\ Working Paper 25278 \\ http://www.nber.org/papers/w25278 \\ NATIONAL BUREAU OF ECONOMIC RESEARCH \\ 1050 Massachusetts Avenue \\ Cambridge, MA 02138 \\ November 2018
}

We thank three anonymous referees and Steven Durlaf (the editor) for useful suggestions. A special thanks to Remi Jedwab, Alex Moradi, Julia Cage, Valeria Rueda, Nathan Nunn, and Adam Storeygard for kindly sharing digitized data and maps. We are also thankful to Sebastian Hohmann, Dozie Okoye, Julia Cage, David Laitin, Marie Lechter, and Lars-Erik Cederman for useful and comments and help. A special thank to Rouven Kunstmann and Felix Meier $\mathrm{Zu}$ Selhausen for very detailed feedback and suggestions. All errors are our own responsibility. The views expressed herein are those of the authors and do not necessarily reflect the views of the National Bureau of Economic Research.

NBER working papers are circulated for discussion and comment purposes. They have not been peer-reviewed or been subject to the review by the NBER Board of Directors that accompanies official NBER publications.

(C) 2018 by Stelios Michalopoulos and Elias Papaioannou. All rights reserved. Short sections of text, not to exceed two paragraphs, may be quoted without explicit permission provided that full credit, including $(\subset$ notice, is given to the source. 
Historical Legacies and African Development

Stelios Michalopoulos and Elias Papaioannou

NBER Working Paper No. 25278

November 2018

JEL No. N00,N10,N77,N87,N97,O10,O43,O55

\begin{abstract}
$\underline{\text { ABSTRACT }}$
As Africa's role on the global stage is rising, so does the need to understand the shadow of history on the continent's economy and polity. We discuss recent works that shed light on Africa's colonial and precolonial legacies. The emerging corpus is remarkably interdisciplinary. Archives, ethnographic materials, georeferenced censuses, surveys, and satellite imagery are some of the sources often combined to test influential conjectures put forward in African historiography. Exploiting within-country variation and employing credible, albeit mostly local, identification techniques, this recent literature has uncovered strong evidence of historical continuity as well as instances of rupture in the evolution of the African economy. The exposition proceeds in reverse chronological order. Starting from the colonial period, which has been linked to almost all of Africa's post-independence maladies, we first review works that uncover the lasting legacies of colonial investments in infrastructure and human capital and quantify the role of various extractive institutions, such as indirect rule and oppression associated with concessionary agreements. Second, we discuss the long-lasting impact of the "Scramble for Africa" which led to ethnic partitioning and the creation of artificial modern states. Third, we cover studies on the multi-faceted legacy of the slave trades. Fourth, we analyze the contemporary role of various precolonial, ethnic-specific, institutional and social traits, such as political centralization. We conclude by offering some thoughts on what we view as open questions.
\end{abstract}

\author{
Stelios Michalopoulos \\ Brown University \\ Department of Economics \\ 64 Waterman Street \\ Providence, RI 02912 \\ and CEPR \\ and also NBER \\ smichalo@brown.edu \\ Elias Papaioannou \\ London Business School \\ Regent's Park \\ Sussex Place \\ London NW1 4SA \\ United Kingdom \\ and CEPR \\ papaioannou.elias@gmail.com
}




\section{Introduction}

\subsection{Motivation}

Over the past two decades, Africa has experienced robust growth. Increases in productivity, structural transformation, and urbanization are improving the lives of millions. Illiteracy is falling, poverty is declining (Pinkovskiy and Sala-i-Martin (2014)), and a growing number of Africans are obtaining secondary and college education. While still high, there are notable improvements in infant mortality and malnutrition, and many African countries have met the ambitious criteria established in 2000 by the United Nations in the Millennium Development Goals (see the 2016 and 2017 Regional MDG Progress Reports). Civil conflict is in remission, and several African countries have moved toward representative rule. Many now refer to an "African Growth Miracle" (Young (2012)). Notwithstanding the overall progress, there remain many challenging issues; Africa continues to be the least economically and institutionally developed part of the world and millions of Africans face insecurity and conflict. There are fears of a looming debt crisis that may halt progress. And the gains have not been equally spread across countries, regions, ethnic and religious groups (Alesina, et al. $(2018 \mathrm{a}, \mathrm{b})$ ). Figures 1a-b reproduce two cover pages from the Economist, illustrating the striking difference in the narrative. On May 11, 2000, Africa was "the hopeless continent" (Figure 1a). Eleven years later on December 3, 2011, Africa had become "hopeful" (Figure 1b).

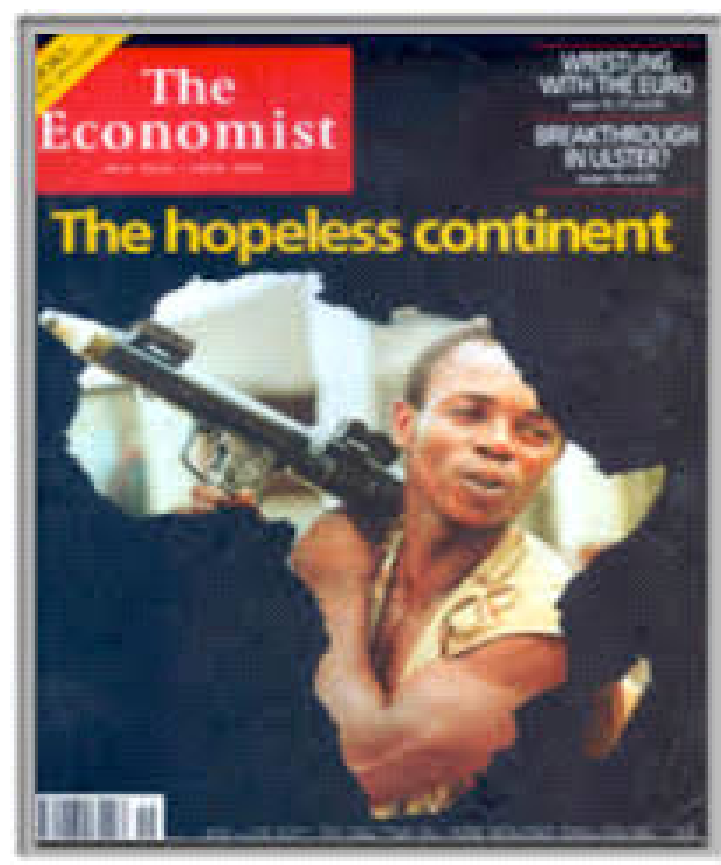

Figure 1a: Economist, May 2000

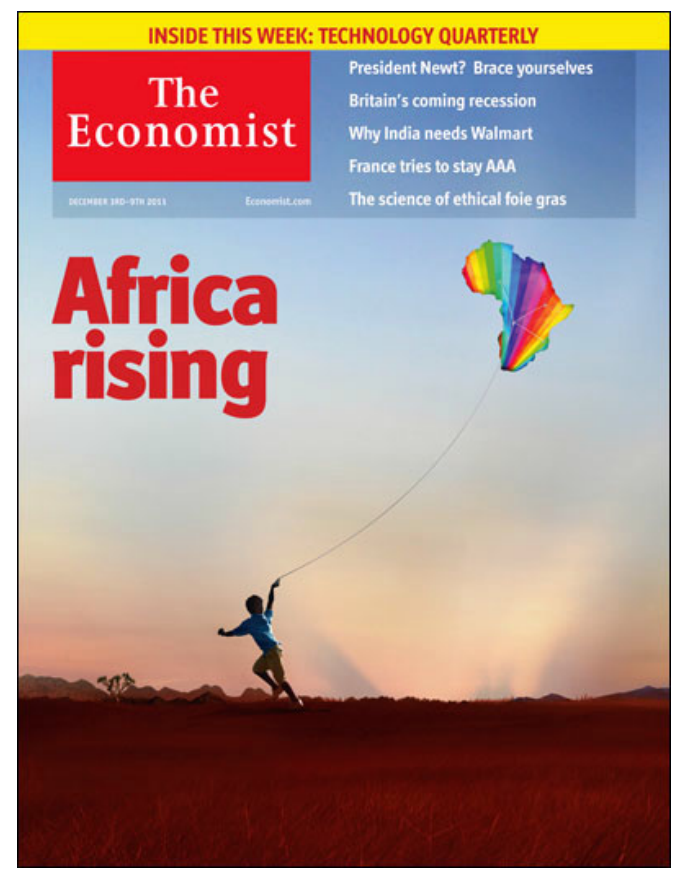

Figure 1b: Economist, December 2011

The attention to Africa's state of affairs among academic economists has followed a similar pattern. Between the 1970s and 1990s, there were only a handful of papers on African growth, politics, and social issues published outside specialized outlets (Hopkins (2009)). And the few papers that appeared in 
general-interest and top field journals mainly drew insights from cross-country comparisons that aimed to explain the "African dummy" (Easterly and Levine (1997)). The lessons learned from these works were limited given the inherent limitations of cross-country correlational approaches; limited degrees of freedom, unobserved factors that are difficult to track, measurement issues, and other endogeneity-related concerns (Durlauf (2009)). However, since the mid-2000s a vibrant stream of works on African political economy has come to life. Comparing this new strand to earlier works, aptly summarized in this journal by Collier and Gunning (1999a), reveals the extent to which the literature has evolved over the last two decades.

First, the scope of the research questions has dramatically expanded, exploring issues related not only to post-independence policies (e.g., foreign aid, democratic transitions, trade and agriculture policies), but crucially opening the black box of Africa's heritage from its colonial and precolonial past (Austin and Broadberry (2014) and Christensen and Laitin (2018)). This shift is motivated by realizing that inappropriate postcolonial policies, authoritarianism, conflict, and corruption (the foci of pre-2000 studies) have historical roots. Second, the new research agenda is interdisciplinary. Influential conjectures put forward by historians and political scientists have been subjected to careful empirical scrutiny, shedding light on their empirical content. Economics research has even addressed inquiries posed by evolutionary anthropology and sociology. Third, the new works have moved beyond cross-country comparisons, exploiting within-country variation. This makes it possible to improve on identification employing stateof-the-art econometric techniques, including the implementation of spatial regression discontinuity designs on a plethora of historical natural experiments. This has been a significant step forward, compared to earlier cross-country growth econometrics (see Durlauf, Johnson, and Temple (2005) for an overview). Fourth, researchers have leveraged non-conventional data sources; individual-level data on attitudes and beliefs from the Afrobarometer Surveys, conflict incidence from the Armed Conflict Location and Event Data (ACLED) and the Uppsala Conflict Data Program Georeferenced Events Dataset (UCDP-GED), health and educational outcomes from the Demographic and Health Surveys, and satellite imagery on land use and light density at night (Lamoreaux (2018)). At the same time, researchers have started conducting their own surveys and lab-in-the-field experiments in places lacking any data, such as rural Congo (e.g., de la Sierra (2018) and Lowes, Nunn, Robinson, and Weigel (2017)). The new research strand is relying on a plethora of historical data, including ethnographic maps, colonial archives and "blue books", and historical accords.

A growing number of empirical studies shows that a sizeable part of Africa's relative economic, institutional, and social underperformance has historical origins. This is readily reflected in broad intercontinental patterns. Figures 2a-2b plot the evolution of real GDP per capita in Africa, Asia, Latin America, Western Europe, and the Western Offshoots (Canada, Australia, the United States, and New Zealand) since AD 1000 and the Second Industrial Revolution (1870), respectively (data come from Maddison). Global output almost tripled during the first wave of globalization (1870 and 1914), but Africa's (and Asia's) output during this period -which coincides with colonization- stagnated. While (parts of) 
Europe and the Americas were enjoying the Belle Epoque, Africans were subject to colonial oppression. The euphoric years regarding Africa's growth following independence in the 1960s did not last long. "Things fell apart" in the late 1960s, 1970s, and 1980s (though as Chinua Achebe eloquently narrated things had started falling apart before independence). Then, as Asia was taking off, once again Africa was left behind.

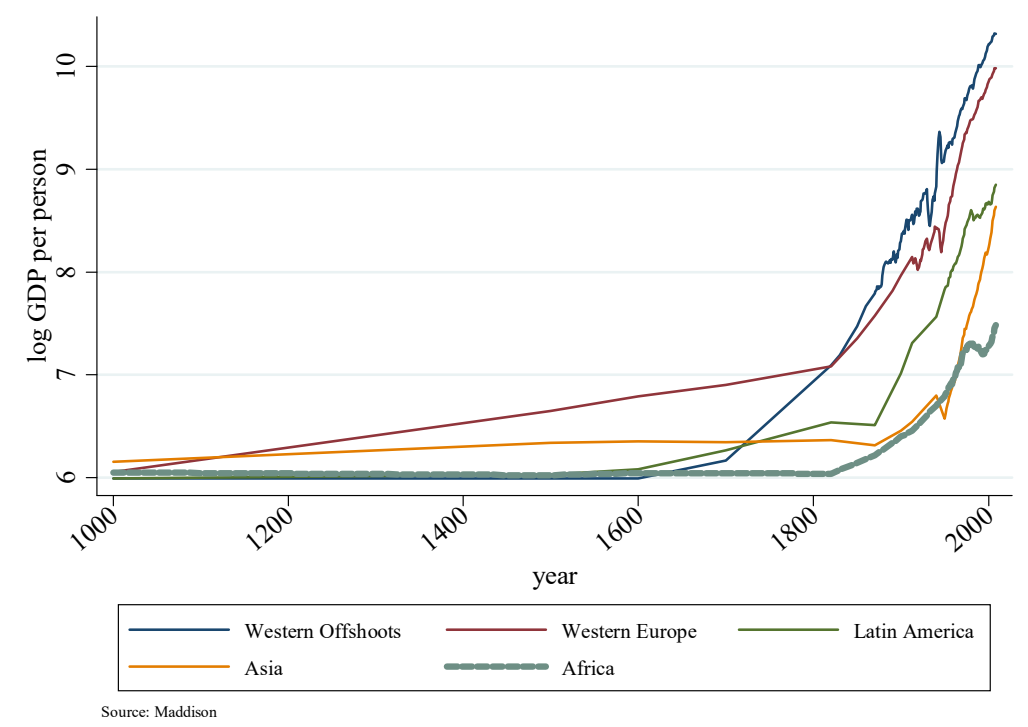

Figure 2a: Evolution World GDP p.c. (Maddison) since 1000

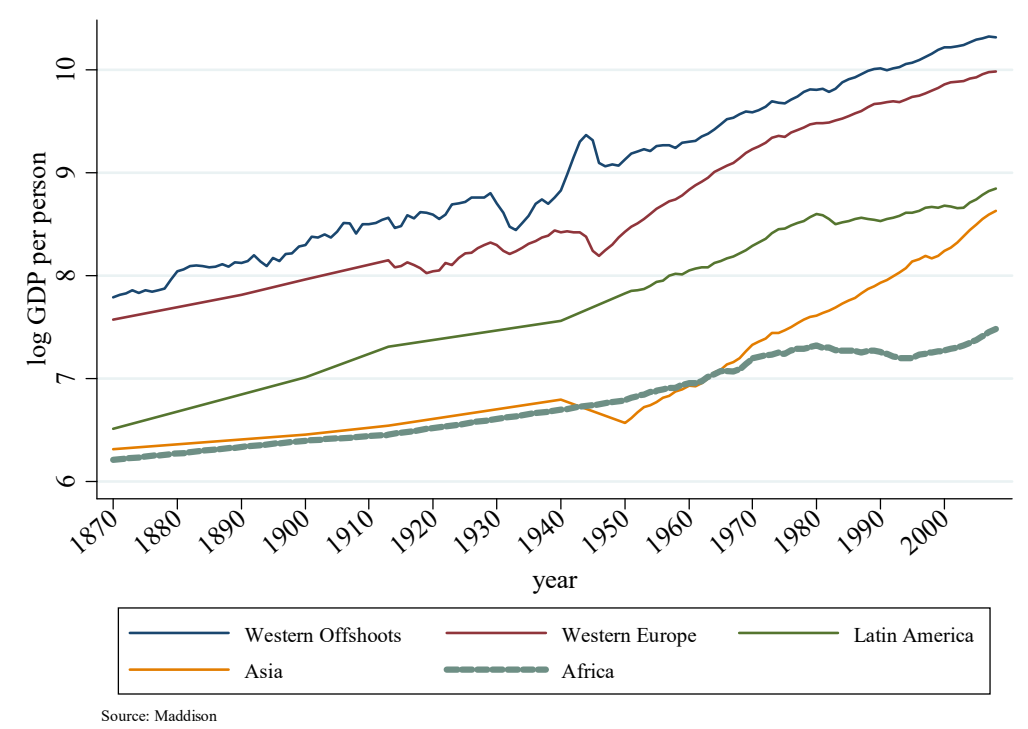

Figure 2b: Evolution World GDP p.c. (Maddison) since 1870

In this survey, we review the exciting research connecting Africa's past to its present. First, we look at the colonial period between the late 19th century and the late 1950s - early 1960s. Despite its short duration (relative to other continents), colonization has been linked to almost all of Africa's pathologies. We discuss works on colonial institutions, such as indirect rule via despotic local chiefs, oppression, and 
concessionary agreements to private corporations that used mercenaries and locals to exploit the continent's riches. We then describe research connecting the limited colonial-era investments in education, health, and transportation infrastructure to post-independence development. Second, we discuss studies linking violence and repression to the artificial drawing of the colonial borders during the "Scramble for Africa" (1860 - 1905), when Europeans carved the largely unexplored continent into protectorates, colonies, and other territorial artifacts. Third, we summarize works showing the lasting legacy of one of the darkest periods of the continent, Africa's slave trades $(1400-1800)$, which seem to have shaped beliefs fomenting distrust and authoritarianism, family structure, conflict, and underdevelopment. Fourth, we review studies revealing the lasting role of deeply-rooted, precolonial, ethnic-specific, institutional, cultural, and economic traits related to political centralization, the mode of subsistence economy, clan structure, and polygyny.

Understanding the role of historical legacies in African contemporary development is important not only from an intellectual standpoint; we believe that it carries lessons for policy-makers, development practitioners, and investors alike. Views on Africa's development have always been polarized. On the one end, optimists see immense unrealized potential from (neoclassical style) capital accumulation and structural transformation that has only recently started and from better management of natural resources. On the other end, pessimists argue (in a "poverty-trap" framework) that Africa's future is bleak, given its history of conflict, extraction, and underdevelopment dating back to the slave trades and the early colonial era. Economists' record in predicting economic outcomes is far from perfect; so we abstain from forecasting. However, we share Confucius' view: "Study the past if you would define the future". Research on the economic history of the region can be useful for practitioners in identifying frictions and impediments as well as in offering guidance on what policies may or may not work. Both macroeconomic policy and micro interventions do not take place in a vacuum. Rather they affect individuals and societies living in complex environments, shaped to a great extent by history. It is, thus, vital understanding how historical legacies influence people's views, attitudes, incentives, and decisions. ${ }^{1}$

\subsection{Broader Strands of the Literature}

The works that we discuss in this review connect to various strands of the literature. First, they are part of the broader research agenda on historical roots of comparative development across the globe. Following the influential studies of Acemoglu, Johnson, and Robinson (2001, 2002, 2005), La Porta, Lopez-de-Silanes, Shleifer, and Vishny (1997, 1998, 1999), and Engerman and Sokoloff (1997, 2002), many subsequent empirical studies uncover the lasting role of various important historical events on a global scale (see Nunn

\footnotetext{
${ }^{1}$ The study of Lowes and Montero (2018) offers a concrete example on the importance of understanding historical legacies when designing policy. Lowes and Montero (2018) show that World Bank development projects in the health sector are less successful in villages of former French West Africa where locals were forcibly injected with medication with severe and often fatal side effects during the colonial period. Colonial-era driven distrust in medicine directly affects foreign aid. Bau (2018) shows that national pension policies crowd out customary young-elderly risk-sharing mechanisms in Ghana and Indonesia.
} 
(2014b) and Abramitzky (2015) for reviews). ${ }^{2}$ There has been a fierce debate on how the colonial experience shaped post-independence development path. Acemoglu, Johnson, and Robinson (2005) stress the legacy of colonial institutions, which for most African regions, were hugely extractive. Glaeser, La Porta, Lopez-de-Silanes, and Shleifer (2004) emphasize the importance of colonial investments in human capital, that in Africa have been limited, while others stress colonial influences in culture (Nunn (2012)) or state artificiality (Alesina, Easterly, and Matuszeski (2011)). The mostly micro studies that we review offer support to all these conjectures.

Second, many of the reviewed studies are part of a new research body that explores the interplay between geography, evolution, cultural and institutional features in shaping preindustrial and contemporary development (see Galor (2005), Spolaore and Wacziarg (2013), and Ashraf and Galor (2018) for literature reviews). ${ }^{3}$ While our focus is not on cultural norms, many of the surveyed papers examine the origins and consequences of deeply-rooted societal practices, such as polygyny and clan structure.

Third, the interdisciplinary nature of recent studies connects them to those in political science, sociology, and in particular African historiography (Hopkins (2009); Jerven, Austin, Green, Uche, Frankema, Fourie, Inikori, Moradi, and Hillbom (2012)). The African Economic History Network (AEHN) has produced an electronic textbook titled The History of African Development (see Frankema and Hillbom (2013) and Akyeampong, Bates, Nunn, and Robinson (2014)). ${ }^{4}$ And while economists, historians, and political scientists have moved in parallel for decades with minimal interaction, they are now much closer in terms of both questions and methodology; for example, economists are now open to case-studies and historians are conducting regression analyses, paying attention to data quality (see Fourie (2016) for a review).$^{5}$

Fourth, the efforts of the recent studies toward identification of causal relationships connect the reviewed body of research to the "credibility revolution" in economics (Angrist and Pischke (2010) and Lee and Lemieux (2010)). While establishing causal relationships in history is challenging, researchers have come up with creative identification schemes. ${ }^{6}$ In this effort, recent research has moved away from crosscountry methods. Most papers exploit within-country/colony variation, quite often combining historical with contemporary georeferenced high-quality data from censuses, surveys, or satellite imagery on lumi-

\footnotetext{
${ }^{2}$ For works on historical legacies outside Africa, see Banerjee and Iyer (2005), Feyrer and Sacerdote (2009), Becker and Woessmann (2009), Iyer (2010), Tabellini (2010), Dell (2010), Nunn and Qian (2011), Acemoglu, Hassan, and Robinson (2011), Acemoglu, Cantoni, Johnson, and Robinson (2011), Grosjean (2011), and Voigtlander and Voth (2012), Grosfeld, Rodnyansky, and Zhuravskaya (2013), Dippel (2014), Cantoni (2015), and Guiso, Sapienza, and Zingales (2016), among many others. Michalopoulos and Papaioannou (2017) provide a collection of summaries of some influential works.

${ }^{3}$ This research followed Jared Diamond (1997) seminal multidisciplinary work on the interplay between geography, culture, and institutions on long-term development. See, among others, Spolaore and Wacziarg (2009), Guiso, Sapienza, and Zingales (2009), Comin, Easterly, and Gong (2010), Michalopoulos (2012), Ashraf and Galor (2013), and Alesina and Giuliano (2015).

${ }^{4}$ See https://www.aehnetwork.org/.

${ }^{5}$ Innovations in digital camera processing, computing technology, and text analysis allowed historians to collect historical micro data; for example, missionary marriage and baptism registers, military records, soldier recruitment rolls, wages, hospital patient records, and colonial tax-collection archives. See, among others, Frankema and van Waijenburg (2014), Jerven (2014), Moradi (2009), Meier zu Selhausen and Weisdorf (2016), and Doyle, Meier zu Selhausen, and Weisdorf (2018).

${ }^{6}$ Fuchs-Schundeln and Hassan (2015) offer a thorough overview of natural experiments in macroeconomics; Diamond and Robinson (2010) provide a collection of historical natural experiments.
} 
nosity and land usage (see Donaldson and Storeygard (2016) for an overview of works using satellite data in economics and Michalopoulos and Papaioannou (2018) and Breinlich, Ottaviano, and Temple (2013) for reviews of regional studies).

Fifth, as Africa's underdevelopment relates to conflict, many studies relate to the literature on the origins and consequences of civil wars (see Blattman and Miguel (2010) and Kalyvas (2007) for eloquent reviews of theoretical and empirical studies and Collier and Sambanis (2005) for case studies from Africa).

Finally, studies in economic history connect to the voluminous body of research examining the role of post-independence African policies on growth (see Bates (1981), Collier and Gunning (1999b), Easterly (2005) and Bates (2008) for general treatments and reviews). The key insight of the literature on historical origins in Africa is that deeply rooted features and historical events related to the colonial era, the preceding slave-trade epoch, and the precolonial period may help us understand the observed variation in civil conflict, authoritarianism, and inappropriate postcolonial policies. ${ }^{7}$

Structure We structure the review in (rough) reverse chronological order. In Section 2 we go over works on the colonial legacy. In Section 3 we review research examining the influence of the Scramble for Africa that partitioned ethnic groups across countries and led to the creation of artificial states. In Section 4 we discuss studies quantifying the impact of Africa's slave trades. In Section 5 we go over studies that examine the consequences of precolonial ethnic institutions, related mostly to political centralization but also other informal ethnic traits. In Section 6 we discuss avenues for future research.

\section{Colonial Legacies}

This Section reviews studies on the role of colonization. First, we discuss the "what if" colonization had not happened debate, present the mapping of colonial Africa, and go over some broad categorizations. Second, we review studies on colonial institutions, such as indirect rule and concessionary agreements. Third, we discuss works on colonial human capital policies, related among others to the role of Christian missions. Fourth, we discuss empirical studies on the legacy of colonial road and railroad investments. Fifth, we present our views on future research.

\footnotetext{
${ }^{7}$ Bates (1983) and Collier and Venables (2008) discuss the role of failed agricultural and trade policies. Bates and Block (2013, 2016) discuss the role of political liberalization on growth and agricultural output, finding positive effects of democratization (see also Papaioannou and Siourounis (2008) and Acemoglu, Naidu, Restrepo, and Robinson (2015)). Bates (2006) reviews works on the political economy of property rights protection and African institutions. Berger, Easterly, Nunn, and Satyanath (2013) analyze the role of cold-war policies on African growth. Miguel (2004) discusses the role of nation-building policies. Easterly (2003) reviews the vast literature on aid and growth. Easterly (2008) summarizes arguments for and against poverty traps in Africa.
} 


\subsection{Preliminaries}

\subsubsection{The "What If" Debate}

The literature on the historical legacies on African development has focused on the colonial period. ${ }^{8}$ The debate on whether colonization benefited or hindered Africa's growth trajectory is dominated by clashing views. On the one hand, there are those who view colonialism as responsible for almost all of Africa's evils. Poverty, low levels of state capacity, endemic corruption, authoritarianism, lack of a strong manufacturing base, and low levels of human capital have all been linked to the colonial era. On the other hand, some scholars, thinkers and politicians argue that European colonization in Africa has been, on average, beneficial; Europeans made investments in transportation, developed state institutions in places lacking political centralization, built schools, and eventually abolished slavery. This more benign viewpoint on colonization has been embraced by both Marxists, like Lenin, and imperialists, like Cecil Rhodes (Heldring and Robinson (2012)).

This debate is not confined among academics, but is present, emotional, and salient on the ground, both in Africa and in Europe. It is exemplified by the recent polemic on the fate of the statute of Cecil Rhodes, who more than anyone else symbolized African colonization, at the Universities of Cape Town and Oxford. Despite demonstrations, Rhodes' statute remained in Oxford, but was removed from the University of Cape Town. Public opinion among the European former colonial powers is also split; in 2005 the French National Assembly passed an act mandating that high school history textbooks stress the "positive values" of colonization, a policy that stands in stark contrast to the request of African groups that the French government pays reparations for "crimes against humanity" committed in Central Africa.

At the core of this century-old debate (that dates back to Hobson (1902) and Gallagher and Robinson (1953)) is the perennial difficulty in forming reasonable counterfactuals. Offering a convincing answer as to how the economies, societal norms and institutions in sub-Saharan Africa would have evolved in the absence of colonialism is not easy. To start with, although we increasingly understand more about the functioning of precolonial African societies, we still do not know much. Moreover, forming a "what if" scenario entails taking a position on how the quite heterogeneous African groups would benefit (or not) from the 19th-century technological, industrial, and commercial revolutions. Colonization in Africa (and elsewhere) entailed both an "extractive" and an "investment" treatment; at the same time, there were population movements (of Europeans to the colonies but also of African people across the continent) further complicating the analysis.

In light of these difficulties, it is not surprising that the works we discuss abstract such macro-scale questions. The recent literature quantifies the impact of specific aspects of colonization, applying credible, albeit mostly "local" identification designs.

\footnotetext{
${ }^{8}$ Austin (2010) and Rodney (1981) provide broad overviews of African colonial history.
} 


\subsubsection{Colonial Africa}

Figure 3 provides an illustration of the continent after it was carved up by colonial powers in late 19th and early 20th centuries (see the discussion of the Scramble for Africa in the next section). At the onset of World War I, only Abyssinia (Ethiopia) and Liberia were not under European rule or "protection." Most of West Africa was "assigned" to France; Afrique Occidentale Française consisted of eight colonial territories (Senegal, Dahomey-Benin, the Ivory Coast, Mauritania, French Sudan-Mali, Guinea, and Upper Volta). France also ruled the vast territories of Afrique Equatoriale Française comprising of what are today the countries of Republic of Congo, Gabon, Chad, Central African Republic, and after WWI also Cameroon. Great Britain controlled the Gold Coast (Ghana), Sierra Leone, and Nigeria in the West, Bechuanaland (Botswana), Northern and Southern Rhodesia (Zambia and Zimbabwe), Nyasaland (Malawi) in South Africa, and Kenya, Uganda, and British Somaliland in Eastern Africa. Reflecting its military and political strength at Bismarck's time, Germany gained territories in West and Central Africa (Togo, Cameroon), South Africa (Namibia), and East Africa (Tanganyika) that were passed to England and France at the end of the Great War. Portugal secured Angola, and Mozambique, as well as Guinea-Bissau and Sao Tome and Principe. The vast area surrounding the Congo basin (Congo Free State) was privately controlled by King Leopold II of Belgium, though after his regime's atrocities reached Europe, he was forced to pass it to the Kingdom of Belgium in 1908 (Belgian Congo).

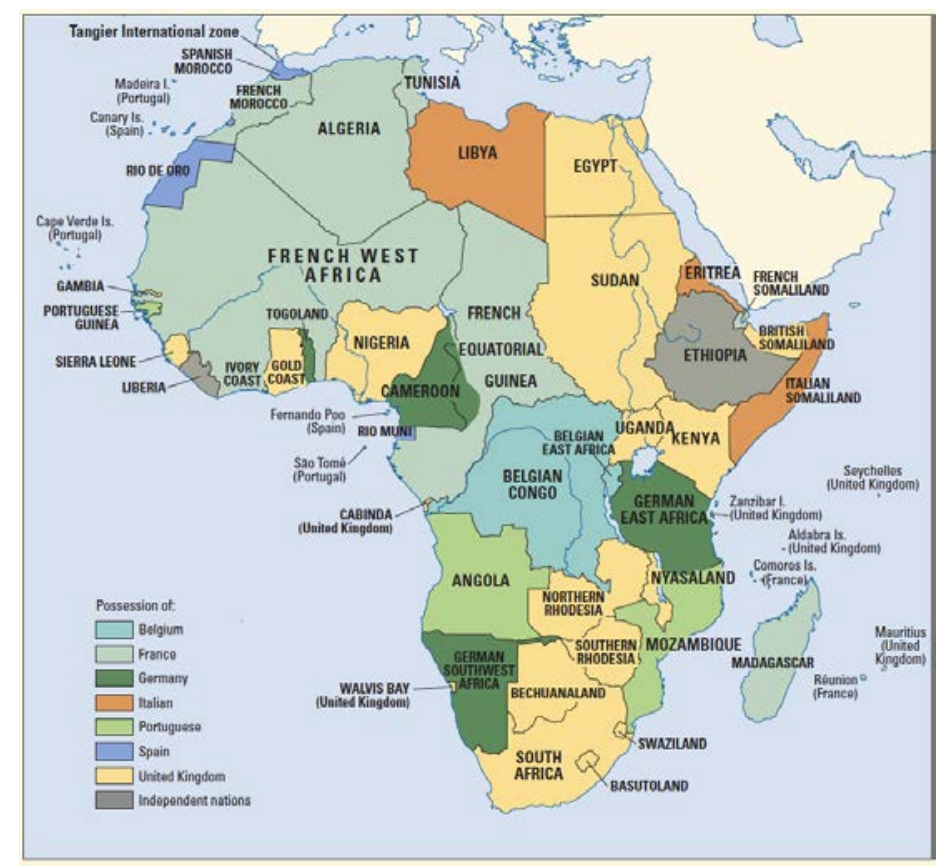

Figure 3: Colonial Africa in 1912 


\subsubsection{Broad Classifications}

The colonial states in Africa differed in many respects that relate to European settlement patterns, the use of direct versus indirect (native rule), the role of Christian missions, the importance of concessionary agreements, investments, state capacity, and many more.

Macro Regions Amin (1972) famously distinguished between three macro regions of colonial Africa. (i) Traditional West Africa, Cameroon, Chad and Sudan formed the Africa of the colonial trade economy, which he further split into coastal "rich" colonies, the hinterland that mostly provided labor to the richer areas, and Sudan. (ii) The traditional Congo basin (French and Belgian Congo, Gabon, and Central Africa) that was defined as the Africa of the colonial concession companies. (iii)The Eastern and Southern parts (Kenya, Tanganyka, Mozambique, Angola, etc.) were part of Africa of the labor reserves, where due to natural resources (gold and diamond in Southern Africa, copper in North Rhodesia) and fertile land, foreign capital "needed to have a large proletariat immediately available". Of course, this a quite coarse classification and often there were important differences even within the same colony, as for example in Mozambique (e.g., Alexopoulou and Juif (2017)).

Settlement Patterns Austin (2008), among others, distinguishes colonies based on European priorities and settlements: (i) Settler-plantation colonies with large European communities (e.g., South Africa, Rhodesia, and to a lesser extent Kenya and Namibia); (ii) Settler-concession colonies with a small-tomodest European presence (like Congo, Angola, and Mozambique); (iii) Non-settler "peasant" colonies with poor soil quality and unfavorable geography (e.g., Mali and Tanganyika); (iv) Non-settler agriculturebased colonies (Nigeria, Gold Coast, Senegal, and Uganda). Hall and Jones (1999) and Easterly and Levine (2016) have established a strong correlation between country-level productivity and the fraction of the population of European heritage in a global sample, a correlation that is also present across African countries.

Direct versus Indirect Rule Another common classification of African colonies regards the use of indirect versus direct rule. Indirect rule was first introduced by Lord Frederick Lugard in North Nigeria, where the British respected and in some form reinforced the politically centralized Muslim kingdoms. The strategy was quickly adopted by all colonial powers that applied it with various twists across the continent. In many (though not exclusively) British protectorates and colonies, Europeans ruled the interior via local chiefs and headmen. In places, where there were strong politically centralized groups, such as in Bechuanaland (Tswana) and Uganda (Buganda), colonizers used the pre-existing traditional leaders and institutional structures. In places where the local ethnic groups were not politically centralized, such as in Sierra Leone (Temne and Mende) or in South Nigeria, the colonial state appointed paramount chiefs to collect taxes, settle disputes, and provide law and order (Mamdani (1996)). In other, mostly (though not 
exclusively) French-administered areas, the colonial state tried to centralize power and rule both coastal areas and the interior with European administrators or by educating a small local elite. Mamdani (1996) connects authoritarian beliefs, despotism, and poorly-performing institutions to chiefs's empowerment; but others argue that indirect rule has had less-negative lasting consequences and that chiefs role slowly diminished during colonization (see Meier zu Selhausen, van Leeuwen, and Weisdorf (2018) for evidence from Uganda).

However, the typically-employed binary indirect/direct rule classification is blurred, as often colonizers applied a mixed approach, and coarse, as there was significant variation within each category. The degree of native rulers' autonomy differed, as well as the role of colonial administrators (Crowder (1964), Berry (1992)). The colonial state adopted a variety of strategies, adapting to the quite heterogeneous geography and changing conditions (Frankema and van Waijenburg (2014)). For example, in Mozambique the Portuguese settled mostly in Lourenço Marques and the coastal city of Beira, with direct rule confined to the south; and, as Portugal was in decline in the 19th century, most of the central and northern areas were assigned to private firms via concessions. Likewise, in West-Southern Africa (Namibia), German colonial administrators applied a mix of direct and indirect rule. In Malawi (Nyasaland) the British initially established direct rule, but after realizing the challenges institutionalized native rule. In current-day Ghana, there was the Gold Coast Colony with direct British rule, the Ashanti region in the Centre that was ruled with the collaboration of local elites, and the Northern Territories with very limited European presence and indirect rule.

Lange (2009) construct proxies of indirect rule in 1955 for 33 British colonies in Africa and elsewhere without major European settlements with the share of colonially recognized customary law cases to the total share of law cases brought in courts and then examines the association of this variable with democracy, state capacity, and political development in 1997 - 1998. The analysis shows that democracy, bureaucratic quality and state capacity are considerably worse in former British colonies where indirect rule was widely practiced, such as Sierra Leone, Malawi, and Nigeria.

British versus Non-British The direct versus indirect rule classification is related to differences between the British common law system (and traditions allowing for a more flexible resolution of disputes) and the more formalistic (French) civil law system, where judges interpret rather than create law. In influential research, La Porta, Lopez-de-Silanes, Shleifer and Vishny (1997, 1998, 1999) present evidence that former British colonies, compared to (mostly) French colonies, have more efficient judiciary, less formalistic courts with faster dispute resolution, more dispersed corporate ownership, less regulated product and labor markets (see La Porta, Lopez-de-Silanes, and Shleifer (2008) for a review). These differences are also present (though somewhat attenuated) across African countries, suggesting that the identity of the colonial power has played a role post-independence, though teasing out the channels is still an open question. 
Overall, the British colonial administration applied a less hands-on approach, as compared to French colonies, giving a more prominent role both to local chiefs and (mostly Protestant) missions. As Crowder (1964) puts it, "the British system depended on the advisory relationship between the political officer and the native authority, usually a chief. The French system placed the chief in an entirely subordinate role to the political officer". British rule was much more accommodative to native institutions and ethnic leaders, while the French administrators often broke indigenous political structures and tried to assimilate chiefs into the colonial administration.

Ali, Fjeldstad, Jiang, and Shifa (2017) examine the impact of colonial identity on ethnic-national identification and state capacity using Afrobarometer data. They first show that individuals in former British colonies are more likely to self-identify with ethnicity than with nation. This applies both in the cross-section and when they exploit within-ethnicity variation at the borders between former British and French colonies in West Africa (see Michalopoulos and Papaioannou (2014)). The same pattern obtains when they exploit variation within Cameroon, which after Germany's defeat in WWI was split between France and the United Kingdom. Second, they show that the chiefs' role is more important and the state's reach is less powerful in former British colonies; this pattern also appears in the spatial regression discontinuity estimates in West Africa. Ali, Fjeldstad, Jiang, and Shifa (2017) attribute these results to British indirect rule; however, they cannot rule out alternative mechanisms, related for example to the common law tradition.

\subsection{Colonial Institutions}

\subsubsection{The Extractive Institutions Thesis}

In a series of influential papers, Acemoglu, Johnson, and Robinson (2001, 2002, 2005) traced contemporary development to the institutions transplanted by Europeans in the colonized world. On the one end of the spectrum, in places with favorable ecology, an absence of endemic diseases, and low population densities (like North America, Oceania, and South Africa) Europeans migrated en masse, installing "inclusive" institutions. On the other end, in high-settler-mortality areas with malaria, yellow fever, and unfavorable geography, such as most of sub-Saharan Africa, Europeans established small communities and "extractive" institutions, as the main objective was to extract and ship to Europe and the Americas minerals and agricultural goods, while at the same time securing trade routes to India and East Asia (see Darwin (2012) and Fieldhouse (1999) for narratives).

The Acemoglu, Johnson and Robinson (2001, 2002) argument was not confined to Africa. While there has been a fierce debate on the primacy of colonial institutions versus human capital investments on longrun development (e.g., Glaeser, La Porta, Lopez-de-Silanes, and Shleifer (2004) and Acemoglu, Gallego, and Robinson (2014)) and the strength of institutional persistence (Albouy (2012)), their argument relates to African colonization specific works. Rodney (1981), Bates (1981), Young (1994), Dowden (2008), and Mamdani (1996), among others, discuss various extractive aspects of Africa's colonization; rampant use 
of forced-labor systems (ironically in an epoch that symbolized Africans' liberation from enslavement), extortion-level taxation on farmers, oppression, mass killings, empowerment of local chiefs who ruled despotically, and more. To a first approximation, the colonial states in Africa have been, in the terminology of Cooper (2002), "gatekeeper" states. They had no (or a very limited) developmental agenda, as they were designed for extraction. Basic public goods, such as education and health, were often outsourced to missionaries. Policing was often delegated to private firms that under concessionary agreements provided law and order either employing mercenaries or empowering local chiefs. The few transportation investments targeted mineral-rich regions or areas with high agricultural potential, as the utmost objective was to ship goods to the industrializing world. As a consequence, the colonial gatekeeper states had "trouble extending their power and their command of people's respect" (Cooper (2002)), a feature that the contemporary African states seem to have inherited (Herbst (2000), Michalopoulos and Papaioannou (2014)).

\subsubsection{Evidence}

We now discuss studies that examine the legacy of some major colonial institutions, namely native rule, concessionary agreements, forced labor, taxation, and oppression. Before presenting the main findings, we should stress from the onset that there was considerable heterogeneity on these practices both across and within colonial powers as well as over time.

Indirect Rule (Africa-wide studies, Sierra Leone and Namibia) As indirect rule correlates with colonizer identity, precolonial political centralization, (Gerring, Ziblatt, VanGorp, and Arevalo (2011)) and geographic-ecological features (De Juan (2017)), it is quite challenging isolating its impact with crosscountry or cross-colony approaches (like the ones of Lange (2009) and Ali, Fjeldstad, Jiang, and Shifa (2017)). Thus, recent works exploit regional within-colony variability which was far from negligible.

Acemoglu, Reed, and Robinson (2014) study native rule in Sierra Leone. In 1896 the British colonial administration appointed paramount chiefs to rule the Sierra Leone protectorate, outside Freetown. Chiefs were accountable to the colonial administration rather than the local communities. Paramount chiefs and subordinate chiefs and headmen (chieftaincy) ruled Sierra Leone's interior throughout the colonial era, often relying on violence and oppression. Acemoglu, Reed, and Robinson (2014) show that the chiefs' power endured colonization, as the country's weak state capacity at independence further eroded during the long-lasting civil conflict. Throughout the post-independence period, chiefs controlled land, settled disputes, taxed production, provided some public goods, and allocated votes to their preferred (in national elections) candidates. Acemoglu, Reed, and Robinson (2014) show that during colonial times state capacity was lower in places with few ruling families. Turning to contemporary outcomes, they show that education and health indicators, along with household assets, are positively related to the number of ruling families suggesting the importance of political competition. They further show that in areas with few ruling families individuals are more likely to hold authoritarian views, though surprisingly low competition is associated 
with higher levels of political participation and social capital, most likely because chiefs are able to capture local civil society. While this study does not exploit some quasi-random variation on chief's competition, it is important as it shows with a phenomenal dataset that traces the chieftaincy for over a century the continuity of de facto political rule and the persistence of rural institutions.

Lechler and McNamee (2018) look at Namibia, an interesting case because the North was ruled via local chiefs, while the German and South African administration ruled directly the Southern provinces. While German colonizers had initially planned to extend power and settle in the more developed North, a rinderpest pandemic killed around $95 \%$ of cattle herds in the South, "freeing" territory in central and southern provinces. The pandemic altered the strategy providing some quasi-random variation. In 1905 the Reichstag passed a resolution stating that policing in South-West Africa should be limited to regions of direct German interest. Soon afterwards the colonial administration put a veterinary cordon fence and in 1907 it institutionalized a formal police boundary separating "white" and "black" West-South Africa. Lechler and McNamee (2018) compare political beliefs and participation using Afrobarometer Surveys on the two sides of the colonial border. The regression discontinuity estimates uncover sharp differences at the border; pro-democracy beliefs and electoral participation are considerably lower on the Northern side of the colonial border that was ruled indirectly via despotic chiefs. Moreover, support for authority and traditional leaders is higher on the Northern side of the border. These results that stem from a credible empirical design offer direct support to Mamdani's thesis that by empowering local chiefs, indirect rule promoted authoritarianism post-independence.

Colonial Concessions (Congo Free State) Colonizers often carved territories and outsourced them to private corporations via concession agreements. The latter used mercenaries, forced-labour, and oppression to exploit resources including rubber, cotton, coffee, palm oil, and other agricultural goods, and minerals. These private corporations had to invest in roads-railroads and build local infrastructure, but in most cases such development investments were minimal. The most illustrative example of this practice was King Leopold II's notorious rule of the Congo Free State, which was his private estate for more than a decade (1895 - 1908). After spending almost all his inheritance, Leopold granted concessions to private corporations of vast territories in exchange for fees. Violence and killings were rampant and according to some estimates close to half of the Congo's population died as a consequence (Hochschild (1998)).

Lowes and Montero (2017) examine the legacy of these strategies focusing on two rubber concessions in Northern Congo, ABIR and Anversoise. Employing a spatial regression discontinuity design that compares outcomes at the border of the concessions, the authors explore their impact on various contemporary outcomes. They uncover several interesting patterns. First, living conditions, as reflected in the Demographic and Health Survey (DHS) composite wealth index (which takes into account access to basic public goods, quality of housing, and ownership of assets), are lower in areas just inside of the concessions. Second, literacy, schooling, vaccination rates, and height are significantly lower inside the historical concessionary 
boundaries. Third, chiefs' characteristics differ considerably at the historical border. Chiefs are less likely to be elected by the local community and public good provisions are worse inside the concession borders. Fourth, locals' respect for authority is significantly higher in villages that were affected by forced labor. Fifth, individuals residing inside the concession boundaries have higher levels of trust and exhibit higher levels of pro-social behavior, suggesting that social capital was strengthened by the extractive colonial practices and the associated violence. Sixth, similar patterns emerge when the authors examine development outcomes across all concessions in Congo Free State. Their results are important, not only because they look at the most exemplifying example of colonial oppression, but because these concessions did minimal (if any) investment, and, hence, the estimates isolate the extractive nature of these policies.

Forced Labor (French Africa, Nigeria, and Rwanda-Burundi) The unfavorable geography-ecology, coupled with the unwillingness of colonial powers to finance the local administrations, prevented the colonial states from building state capacity. The absence of well-defined private property rights made it hard to establish tax systems, and, hence, most colonial administrations relied on forced labor practices, mainly in-kind labor taxation and conscription. Forced labor also emerged due to the low population density and the associated relative scarcity of labor, as compared to land (see Gardner (2012) for an overview).

Waijenburg (2018) studies the French West and Equatorial African corvée system (prestations) under which each adult African male had to work a given number of days per year on a designated public project without pay. [In some cases some minimal pay was provided, especially for Africans employed for six months or more.] Doing some "back-of-the-envelope" calculations using the share of adult male population and wages of unskilled labor, she argues that this system was a considerable boost to local revenues; in the pre-WWI period the implied additional income that the colonial state got from prestations relative to the size of the budget is around $50 \%$ (e.g., in Ivory Coast is $52 \%-56 \%$, in Mauritania $83 \%-86 \%$, in Congo and French Congo around 30\%) and falls only after the mid/late 1920s.

In the same vein, Archibong and Obikili (2018) calculate the value gained by forced labor, in particular by convicts, in colonial Nigeria from 1920 til 1938. The colonial administration imprisoned thousands of locals for petty crimes or for refusing to pay farm taxes, and in turn used the convicts as cheap labor in public work projects. Their analysis first shows that arrests increase when wages rise, in line with historical evidence that the prison system was used to extract labor surplus. Then they estimate that the share of convict labor on public works total expenditure ranges from $40 \%$ to $140 \%$.

Quite often forced-labor systems were built on pre-colonial labor tribute systems that were quite pervasive. For example in Uganda the British pursued a modified version of the indigenous kasanvu tribute system, where locals could either work without pay for some days or in exchange cultivate cotton, which brought in tax revenues. Blouin (2016) examines the impact of a discriminatory forced-labor system imposed by the Belgian colonial administration in Rwanda and Burundi in 1931 that introduced village-level coffee quotas; this policy empowered all Tutsi chiefs to extend the use of forced labor, almost exclusively 
from Hutu farmers, to meet the quotas. Blouin (2016) first shows that the discriminatory colonial policies weakened a widely-used precolonial risk-sharing institution. The Uhuhake patron-client arrangement involved a Hutu caring for the male cattle of a Tutsi, in exchange for meat and milk during the hungry season or in the event of a bad harvest. Belgians maintained the Ubureetwa arrangement under which a client, typically a Hutu, was providing labor to a landlord, typically a Tutsi, in exchange for security. Blouin (2016) shows that Hutus from communities affected by the forced-labor system exhibit less trust today and are less likely to use this risk-sharing arrangement. The uncovered link between colonial discriminatory policies and lower levels of interethnic trust is in line with the widespread belief that Belgian policies favoring Tutsis against Hutus played a role in ethnic violence that peaked during the 1994 genocide.

Agriculture and Urban Tax Policies; State Capacity In some cases, the colonial state taxed directly farmers, while at the same time coming-up with "innovative" alternative extraction schemes. As emphasized by Bates (1983) in his masterful analysis of agriculture dynamics during the colonial and postindependence period, Europeans established trade monopsonies to keep agricultural prices and wages low. Quite often these were accompanied by forced-labor policies that also aimed to depress wages. Tadei (2017) conducts a thorough examination of trade policies and effective agricultural taxes across all French colonies from 1898 to 1959. Combining at-the-port prices of agricultural exports (peanuts, palm kernels, cotton, and cocoa) with information on trade costs and prices of these goods in global markets, he approximates the prices paid to African farmers. He then analyzes the evolution of price gaps, which can be thought of as an index of extraction across goods, across the main administrative regions of French West Africa and Equatorial French Africa. Extraction, which is especially high for cocoa and cotton, peaks during the world wars, most likely because of global shortages.

Frankema and van Waijenburg (2014) present interesting statistics of native tax rates and local revenues from urban and rural taxation for around 30 British and French colonies from early 20th century til the onset of World War II. ${ }^{9}$ Their cross-colony analysis reveals the following: First, while the fiscal (revenue raising) capacity of British colonies and protectorates was higher in early 19th century, Frenchadministered territories caught up after the Great War. Second, variability was way higher among French colonies, suggesting that the policy of assimilation and direct control was both effective and ineffective. Third, geography appears to be the most significant correlate of fiscal tax revenues that were considerably lower in landlocked, as compared to coastal, territories for both French and British ruled areas.

Oppression (Madagascar) Garcia-Ponce and Wantchekon (2011) study the consequences of colonial oppression in Madagascar that culminated in the 1947 Malagasy Uprising, which was eventually crushed by French forces in one of the bloodiest episodes in colonial Africa (resulting in as many as 30, 000 to 100,000

\footnotetext{
${ }^{9}$ Cogneau, Dupraz, and Mesple-Somps (2018) compile a more detailed dataset of public finances in 9 French and 4 British colonies in West Africa from 1900 till independence. They also find small differences between French and British colonies on sources of colony revenue and expenditure.
} 
casualties). The authors exploit geographic and ethnic differences in the revolt (concentrated in the East) to assess its legacy, using Afrobarometer data on beliefs and attitudes today. The OLS estimates show that individuals from ethnic groups that were affected the most by oppression are less likely to value freedom today. To improve identification, the authors employ "matching" estimators, effectively conditioning in a nonlinear way for observable features. They also report spatial regression discontinuity estimates, utilizing the fact that due to the mountainous terrain in the center of the country, the rebellion did not spread west.

\subsubsection{Taking Stock and Future Work}

The recent empirical literature provides ample evidence on the deleterious effects of various colonial institutions on contemporary economic, political, and social development. These findings accord well with the historical narratives and the more qualitative works in political science. A key message coming from our reading of history is heterogeneity. Indirect rule, for example, took various forms across the continent, even when one looks within British or French Africa. Likewise, while the concessionary agreements in Congo were very extractive, in other cases, mostly in Southern Africa, such agreements were accompanied with infrastructure investments that may have positive lasting effects.

However, besides expanding on the analysis of specific colonial institutions, we believe that future work should try to move beyond case studies. It would be interesting to assess the impact of indirect and direct rule across the continent using data with Pan-African coverage (such as IPUMS, DHS, Afrobarometer, luminosity, and land usage). This of course requires digging into historical accords and colonial records to provide country and even regional classifications of direct-indirect rule, a non-trivial task as in practice this was not a binary outcome (see Lange (2009) for an early effort). Future work could also distinguish between the different periods of colonization, as European's objectives and investments changed considerably over time (see van Beusekom and Hogdson (2000)).

\subsection{Human Capital Colonial Investments}

\subsubsection{A Primer}

Average years of schooling and literacy rates in Africa have been considerably lower than in other continents throughout its post-independence period (Barro and Lee (2013)). At the same time, there is substantial cross-country and within-country variation in educational attainment (Alesina, Hohmann, Michalopoulos, and Papaioannou (2018b)). Given the strong inertia in the supply and demand for education, many trace Africa's educational gap to colonial times. Limited colonial investments in education, the construction of few primary and even fewer secondary schools, and the minimal promotion of universities have played a role, perhaps a crucial one, in Africa's relative economic underperformance (Glaeser, La Porta, Lopez-deSilanes, and Shleifer (2004), Easterly and Levine (2016)).

As summarized by Fourie (2013), formal education started making inroads into the continent with the expansion of Islam and the rise of commerce in Northern Africa and the Sahel. Timbuktu and other 
places in North Africa became educational hubs by the 14th to 15th centuries. Yet, formal education did not diffuse to the South for centuries, the exception being South Africa where the Dutch and English started building schools in the 17th century. Genadendal, founded by George Schmidt in 1738, was the first mission station in South Africa (Cape Colony). Protestants established a few missions in Africa at the turn of the 19th century (see Mantovanelli (2014) for a discussion). In a few places, such as in Mauritius and in the coastal colony of Freetown (in Sierra Leone) enrollment rates were considerable (exceeding 20\%) even before the Scramble for Africa and the consolidation of colonial rule in 1870s - 1880s (Frankema (2012)).

Protestant missionaries were at the forefront in the early colonial era, as the Roman Catholic Church was adversely affected by the Napoleonic wars. This was to change with the arrival of European settlers in the mid-to-late 19th century and the abolition of slavery. The widespread ideology at that time was that Europeans had a moral duty to "liberalize" African societies, especially given the legacy of the slave trades; this meant converting Africans to Christianity and increasing literacy. At the same time, there was growing demand among Africans for Christianity both for spiritual, educational, and professional reasons.

Sir Thomas Fowell Buxton's "The African Slave Trade and Its Remedy," published in 1839, helped popularize the view that promoting commerce, investing in education, and converting to Christianity would help Africa enter a sustained development path. The "evangelization" of the "slave coast" -stretching from the Volta River to the Niger Delta- was a priority for the Catholic Church and Protestants alike (Wantchekon, Klasnja, and Novta (2015)). Many missions were founded in places where slavery was practiced and in coastal areas that suffered the most during the slave trade era (Johnson (1967), Okoye and Pongou (2014)). Because of malaria and the absence of a transportation network, missionaries often started their evangelical work along coastal areas; moving inland only after the introduction of the quinine in 1850s (see Jedwab, Meier zu Selhousen, and Moradi (2017)). The expansion of Islam in Northern Africa and parts of West Africa acted as an impetus for Europeans to Christianize the local population.

However, human-capital investments were limited, as the colonial state wanted to minimize the costs. Colonial educational policies were part of broader strategic considerations, related to the decision to rule directly or via locals and the size of the European settler communities (Acemoglu, Gallego, and Robinson (2014)). There was considerable heterogeneity across colonial powers with average educational attainment being higher among British colonies. The French ideology was to develop a centralized public educational system with French as the main language. As a general rule, local languages were not taught, and a major objective was to create a local educated elite. In contrast, British colonial administrators outsourced educational investments to Christian missions, who received modest subsidies for building schools; the general objective was to reach out to as many pupils as possible (Frankema (2012)). Classes were often taught in indigenous languages (rather than in English), and local teachers were employed (see Cogneau and Moradi (2014) and Frankema (2012) for a discussion and additional references). ${ }^{10}$ Nunn (2010) documents

\footnotetext{
${ }^{10}$ For example, Jedwab, Meier zu Selhousen, and Moradi (2017) report that in Gold Cost in 1890 there were six times more missions with African priests as compared to missions with Europeans. In Uganda in 1904, European missionaries represented just $3 \%$ of the workers in Protestant missions, as more than 2, 500 locals taught in the 162 mission stations (Meier zu Selhausen,
} 
that in the 1940s, $97 \%$ of the student body in British-ruled Ghana and Nigeria was attending missionary schools. In South Africa, out of 5, 590 schools only 230 were state-sponsored, while 5, 360 were supported by Christian missions (Berman (1974)). In the British Gold Coast, $90 \%$ of students attended missionary schools (Cogneau and Moradi (2014)). Frankema (2012) estimates that the share of mission schools in total enrollment in British Africa exceeded 90\% both in 1900 and in 1938. In contrast, in (initially German and post-WWI French-controlled) Togoland, there was an almost equal split of students in missionary and state-run schools. The role of Christian missions was also crucial in Belgian and Portuguese colonies, whose local administrations had limited resources and often followed indirect rule strategies. However, while there were differences in literacy rates between British and non-British territories, the situation was more delicate as variability in enrolment rates within British Africa was as large as between British and non-British colonies (Frankema (2012)). The colonial powers start investing in education (and health) only after World War II.

\subsubsection{Africa-Wide Studies}

The literature assesses the role of various aspects of the colonial educational policies on contemporary development. Some works take a pan-(sub-Saharan) African approach, while others zoom in on particular countries. ${ }^{11}$ Before we discuss the Africa-wide studies, we need to stress that the literature uses digitized maps that by no means reflect the full picture. The employed pan-African data capture the large, early established missions, with a sizable portion of European settlers, located on average in better connected areas with a more favorable geography (Jedwab, Meier zu Selhousen, and Moradi (2017)). The Roome (1924) map (depicted in Figure 4) misses missionary stations where Africans performed the main religious, educational, and health provision duties. ${ }^{12}$

Contemporary Education Nunn (2014a) links contemporary data on education from the Afrobarometer Surveys with Roome's map on the location of early main Christian missions around the late 19th century (see Figure 4 below) and information on the spatial distribution of African ethnicities at the

\footnotetext{
van Leeuwen, and Weisdorf (2018)).

${ }^{11}$ Many empirical studies examine the legacy of Christian missions outside Africa. Mantovanelli (2013) and CastelloCliment, Chaudhary, and Mukhopadhyay (2016) associate Protestant and Christian missions with contemporary literacy, tertiary education, and development in India. Bai and sing Kung (2015) find sizable knowledge spillovers in Chinese districts with Protestant missions, an intriguing result as very few Chinese converted to Christianity. Caicedo (2017) associates human capital and industrial specialization with the location of Jesuit missions in Brazil, Argentina, and Paraguay. Although Jesuits were eventually expelled from these countries, the influence of their early investments persists. Waldinger (2017) shows that literacy and educational attainment are higher in Mexico in proximate areas to Mendicant Catholic missions; proximity to colonial Jesuit missions is not systematically linked to education, though it correlates with the Catholic share.

${ }^{12}$ As Frankema (2012) puts it: "The term "mission school" may raise the impression of an institution run by male, European, ordained pastors or priests in isolated areas across the African tropics, but this stereotypical image is misleading. As missionary societies started to increase their activities in Africa, much work (religious ceremonies and services, schooling, medical care, etc.) was performed by African converts, not by foreigner missionaries. During 1903 and 1925, seven out of eight official staff members in the Protestant missions were African. In the mission schools, the ratios were even more skewed. In Uganda in 1938, for instance, 8,456 African teachers taught in primary schools. The 285 European teachers constituted barely 3 percent of the total number of primary-school teachers."
} 
time of colonization (using George Peter Murdock's Ethnographic Atlas) to examine the legacy of Christian missions on education. The 2005 Afrobarometer Surveys cover around 21,000 respondents from 17 sub-Saharan African countries.

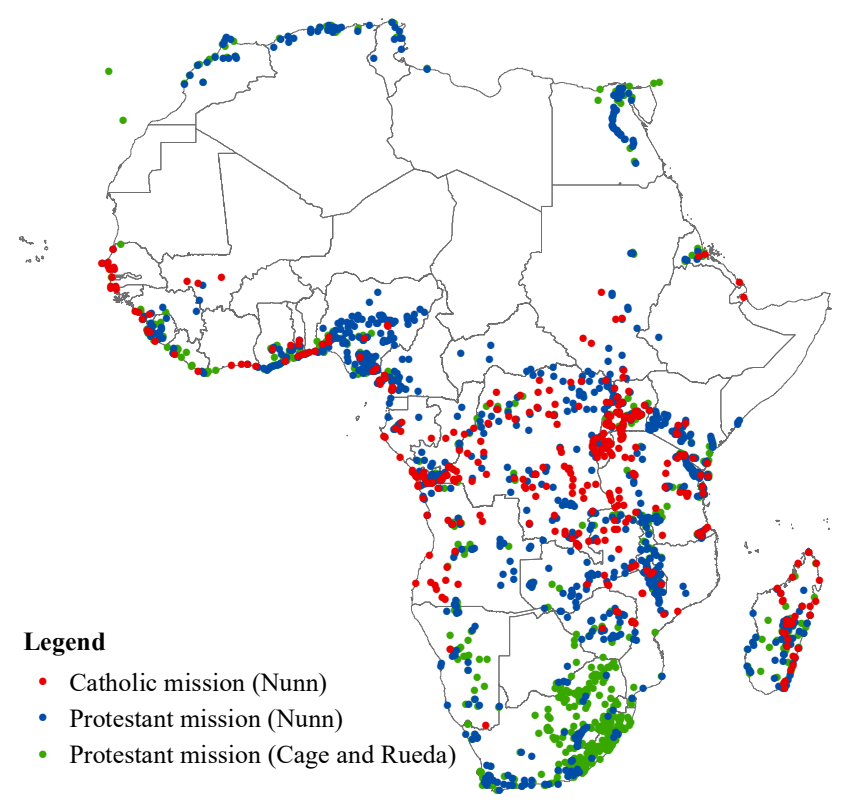

Figure 4: Christian Missions (Nunn (2010) and Cage and Rueda (2016))

Nunn (2014a) associates respondents' education with an indicator that identifies individuals living close to colonial missions and an ethnicity-based variable quantifying exposure to Christian missions (the log number of missions per 1,000 square kilometers in the ethnicities' ancestral homeland). Both independent variables are significant, pointing to the importance of Christian missions. While the placement of missions was not random (as Christian missionaries settled in places with a lower disease burden, close to the coast), these correlations are robust to the inclusion of various individual controls, location characteristics, and country fixed effects.

The role of Protestant missions is quite strong, while exposure to Catholic missions is quantitatively smaller and less precisely estimated. This finding is in line with Protestants' prioritization of literacy, stemming from Sola Scriptura (that each Christian needed to be able to read the Bible) and other research (Gallego and Woodberry (2010) in Africa and Mantovanelli (2013) in India). Nunn (2014a) also uncovers interesting gender-specific heterogeneity: exposure to Protestant missions is especially beneficial for female education, less so for males. In contrast, exposure to Catholic missions has a positive and significant long-run impact on male education, but precisely zero effect on female education.

In ongoing work Alesina, Hohmann, Michalopoulos, and Papaioannou (2018b) also uncover a strong within-country positive association between proximity to Protestant missions and literacy using Census data from 23 African countries, covering millions of respondents. They also find strong inertia, as the impact of Protestant (and to a lesser extent Catholic) missions is quite strong for cohorts born during 
colonial times, at independence, and in the most recent decades.

Religious Conversion Nunn (2010) examines the impact of (early) Christian (main) missions (with considerable European presence) on religious conversion. Accounting for various observable individual and location characteristics and exploiting within-country variation, he reports that respondents residing close to colonial missions are more likely to adhere to Christianity today. He also shows that individuals from ethnic groups that benefited from Christian missions are more likely to follow Christianity today. While the location of missions is far from being random, this work shows that "supply" played a role, an important result as the African historiography stresses the role of Africans' desire to convert to the new religion.

Civic/Social Capital Cagé and Rueda (2016) assess the impact of main Protestant missions on civicness and social capital, placing an emphasis on the role of the printing press. ${ }^{13}$ They combine data from the 2005 and 2008 Afrobarometer Surveys covering around 28,000 individuals with geocoded historical maps from Beach and Fahs (1925) of the location of early (by 1903) Protestant missions detailing the specific activities of those missions (e.g., health clinic, school, printing press). [Figure 4 shows the additional Protestant missions.] Out of the 723 early Protestant missions, 93 had a printing press. The within-country estimates reveal that proximity to missions with a printing press increases contemporary literacy and also newspaper readership and trust. Distance to missions with schools and a printing press also negatively predicts the presence of schools in 2005 and 2008; and there is no link between proximity to colonial-era Christian missions and contemporary health. When looking within democracies, they find a link between proximity to missions with a printing press and political actions, though not on turnout and voting registration. To assuage selection concerns, that Protestant missionaries imported the printing press in places with initially higher levels of development or higher growth potential, they perform many sensitivity checks. These results complement the cross-country evidence of Woodberry (2012) detecting a robust correlation between the duration of exposure to Protestant missions and democracy in non-western societies (see also Woodberry and Shah (2004) and Gallego and Woodberry (2010)).

Linguistic Policy Laitin and Ramachandran (2016, 2018) put forward a novel hypothesis connecting colonial languages to contemporary human development; they argue that as the official languages during colonization -and post-independence- (English, French, Portuguese) were quite distant from the indigenous languages this impeded human capital accumulation. Working on a global sample, Laitin and Ramachandran (2016) present cross-country evidence linking linguistic distance from the official language to low levels of education and health in a global sample. In Laitin and Ramachandran (2018) they further show that linguistically diverse countries in Africa were more likely to adopt the colonial language as the

\footnotetext{
${ }^{13}$ Dittmar (2011) presents cross-regional evidence from Europe linking the spread of the printing press to city growth and urbanization.
} 
official one, which in turn lowers human development (health, education) and fosters ethnic identity. The authors nicely support their argument with within-Africa cross-country regressions and narratives. ${ }^{14}$

HIV In subsequent work Cagé and Rueda (2017) uncover a negative aspect of Christian missions. Using DHS data, they show that HIV prevalence is significantly higher in regions with Christian missions, especially when a mission lacked health clinic; a one-standard deviation increase in the proximity to a mission increases HIV prevalence by 1 to $1.5 \%$ of a standard deviation. Cagé and Rueda (2017) further show that disapproval of condom use and contraception may explain this persistent adverse impact. In contrast to the overall negative effect, HIV prevalence is lower in areas close to missionary hospitals and clinics; quantitatively a one-standard deviation increase in the proximity to an health investment decreases HIV prevalence by $2 \%$ of a standard deviation. Part of this positive effect comes from less risky sexual behavior closer to a historical health investment. Mantovanelli (2014) also shows that by shaping moral values and beliefs Catholic missions may have helped prevent the spread of HIV. And while he documents a small negative impact of Catholicism on condom use, its magnitude is overshadowed by the adoption of safer sexual behavior.

Family Structure Fenske (2013) associates Christian missions and colonial-state investments in education (in French colonies) with polygyny, which, although in decline, is still widespread. Districts of French West Africa that received more colonial teachers and areas that received more Christian missions have lower polygamy rates today. ${ }^{15}$ Interestingly, Fenske (2013) fails to find a significant association between post-independence educational investments and polygamy. Quasi-random variation in educational expansion in Nigeria, Zimbabwe, Sierra Leone, and Kenya has not reduced polygamy. These patterns hint that colonial and missionary education may have been more powerful sources of cultural change than modern schooling.

\subsubsection{Case Studies}

A couple of interesting empirical papers examine the role of colonial and missionary human capital (education and health) investments in specific territories.

French West Africa Huillery (2009) examines the long-term impact of the quite limited colonial investments in schools and health clinics in French West Africa (a vast territory of 4.8 million $\mathrm{km}^{2}$ with a population of around 12 million at the turn of the 20th century). As there were just a few Christian missions, she studies the role of investments by the colonial state from 1910 to 1928. Her study uncovers a sizable legacy of colonial human capital investments. OLS specifications imply that adding 10 teachers per

\footnotetext{
${ }^{14}$ Laitin, Ramachandran, and Walter (2017) and Ramachandran (2017) provide evidence on the adverse effects of using European languages in African schools on various student performance outcomes, from Cameroon and Ethiopia.

${ }^{15}$ In line with this, Kudo (2017) shows that proximity to the major Livingstonia mission in Malawi is associated with lower polygyny, higher female marriage age, and somewhat higher educational attainment.
} 
100, 000 inhabitants during the colonial era translates to higher educational attainment of 7 - 12-year-old children by $10 \%$, a non-negligible magnitude, as the mean-median enrollment across the 98 districts is $33 \%-34 \%$ and the standard deviation is $16 \%$. Adding 10 more doctors from 1910 to 1928 translates into a lower likelihood that a young child would suffer stunted growth in 1995 by 5 percentage points, roughly half of a standard deviation (mean-median 37\%). While investments in clinics, schools, and overall spending are correlated and the sample is limited (less than 100 districts), the regressions suggest that early investments in education matter for contemporary education-related outcomes, while colonial investments in clinics and hospitals correlate with contemporary health. To account for non-random placement of colonial investments, Huillery (2009) controls for precolonial features, including political centralization and early development. She also associates contemporary outcomes with colonial investments across neighboring districts that are likely to have similar geography-ecology. The analysis yields only slightly attenuated estimates.

French Equatorial Africa and Cameroon Lowes and Montero (2018) examine the legacy of a large medical campaign that the French military undertook in the vast French Equatorial Africa (Chad, Republic of Congo, Central African Republic, Gabon) and Cameroon aiming to combat malaria, syphilis, and mostly sleeping sickness caused by the TseTse fly. These campaigns had dubious efficacy, while at the same time they had substantial adverse side effects, including gangrene, blindness (for around 20\%), and death. Using archival data, Lowes and Montero (2018) map the location of the campaign visits for each year over the period 1921 - 1956 and construct location-specific proxies of the campaigns' intensity. They then examine the legacy of these campaigns. First, they show that the success of World Bank's health projects is significantly lower in areas with greater exposure to the colonial campaigns. Second, trust in medicine, as reflected on individual's consent to a free blood test, and father's consent for a measles vaccination are both much lower in areas much-affected by the colonial medical campaign. Third, health outcomes (vaccination, HIV, anemia) are worse in affected areas. These patterns apply to all countries except for the part of Cameroon that was administrated by the British after the Great War. The results of Lowes and Montero (2018) are important, as they provide direct evidence on a hypothesized mechanism explaining distrust in medicine and the relatively low uptake of heath services in many parts of Africa (Dupas and Miguel (2017)). At the same time, they illustrate the usefulness of understanding historical legacies for policy in an area that is the major focus of international agencies and African governments.

Nigeria Okoye and Pongou (2014) examine the impact of the main Catholic and Protestant missions in Nigeria using Roome (1924) map. In the first part of their paper, they examine the factors determining the location and expansion of Christian missions. Missions were mostly carried out in the South, as it was easier, less costly, and less risky. The church also prioritized ethnicities affected by the slave trade. The North was hard to access, especially before the railroads were built, as it was indirectly 
ruled by the Islamic Sokoto Caliphate and the Borno Emirate. Since these states opposed the expansion of Christianity, the British administration -rather than the Christian- missions was in charge of education. And its investments were minimal. Second, Okoye and Pongou (2014) correlate contemporary DHS education data covering around 30,000 individuals in 2008 with the number of Christian missions per 1,000 $\mathrm{km}^{2}$ of a respondent's ethnic homeland, as portrayed in Murdock's ethnographic map (see below) and indicator variables identifying individuals residing close $(25 \mathrm{~km}$ and $50 \mathrm{~km})$ to colonial missions. There is a strong legacy of colonial missions on contemporary schooling, even after controlling for individual and location characteristics, state fixed effects, ethnicity specific constants and proxies of precolonial development (which correlate negatively with contemporary education). Third, to improve on identification the authors "instrument" for colonial missions using distance to the coast and distance to Timbuktu, Mali, an important center of Islamic scholarship. The 2sls coefficients are highly significant, implying that an additional Christian mission per $1,000 \mathrm{~km}^{2}$ of an individual's ethnic homeland increases, on average, contemporary schooling by approximately two more years. Fourth, Okoye and Pongou (2014) explore heterogeneity. They find that the effect is considerably stronger for females, and there is persistence in the supply of schools. And people from all religions, including Muslims, gain if they live close to missionary schools.

Benin Wantchekon, Klasnja, and Novta (2015) assess the impact of colonial schools (built by Catholic missionaries and French authorities) in central and northern Benin, using a unique longitudinal dataset that tracks down the very first students in colonial schools and their descendants, as well as their contemporaries, who did not get formal education. There are two sets of comparisons: between students attending colonial schools (and their descendants) to other people in the same village, and between nearby villages (ranging from 7 to $20 \mathrm{~km}$ ) with and without a colonial school. The analysis yields many interesting patterns, which, given the close-to-random placement of schools at such a fine resolution (set up before the expansion of the colonial administration and institutions) allow for causal interpretation. First, individuals who attended colonial schools (first generation) have higher living standards and better social networks, and are more likely to work outside agriculture. They are also more likely to be politically active, standing as candidates in elections. Second, when looking at their descendants, Wantchekon, Klasnja, and Novta (2015) find that parents' education has a significant effect on their children's (second generation) educational attainment, living standards, and social networks. Third, there are considerable human capital spillovers within extended families, as nephews and nieces also benefit. They are almost as educated as the students' children. Fourth, there are large village-level externalities. Descendants of the untreated in villages with schools have substantially better outcomes than descendants from villages without schools.

Madagascar Wietzke (2015) studies the long-term impact of colonial settlements and missionary schooling investments across 107 Madagascar districts. He documents small and statistically insignificant correlations between various proxies of contemporary well-being and missionary schools, while there is a 
significant link with the number of schools and teachers. At first glance these results do not support the colonial human capital channel; yet, the insignificant long-term correlation may reflect spillovers (from the "treatment" to the "control" group). In line with this, Wietzke (2015) shows considerable migration across Madagascar districts.

Togo-Ghana Cogneau and Moradi (2014) examine the impact of colonial policies on education, studying quasi-experimental variation in Togo, a German colony that was partitioned after World War I between France and the United Kingdom (Ghana). They uncover a notable divergence in literacy rates post-WWI on the British side of the border and especially in the South, where many Christian missions established schools. These differences persisted, in spite of sizable post-independence investments in both countries, and contemporary literacy rates and primary education completion rates are significantly higher on the Ghanian side of the border.

Cameroon In the same vein, Dupraz (2015) examines the impact of the partitioning of German Cameroon after WWI between France and the United Kingdom on education, using detailed cohort-based data going back to the colonial era. He finds positive effects on primary education on the British side of the border for cohorts born during the colonial era; however, they dissipate after independence.

Gold Coast (Ghana) Jedwab, Meier zu Selhousen, and Moradi (2017) examine the origins and consequences of Christian missions in Gold Coast. Their work is important as they pay close attention to measurement. Digitizing colonial Blue Books, they document in detail the annual expansion of all types (major, minor, with and without significant European presence) of Christian missions from 1751 until 1932. They then show that missions were systematically placed. Initially missions were established in areas with a low prevalence of malaria, almost exclusively along the coast and close to precolonial trade routes (though the Ashante allowed missionaries in their region after 1890), see Michalopoulos, Naghavi, and Prarolo (2018) for the importance of pre-industrial trade routes for the expansion of Islam in Africa and beyond. Over time, missions moved inland following the construction of the railways, reaching the palm oil and cocoa-producing regions by the turn of the 20th century. They only reached the northern regions after the Great War, again following the expansion of roads and railroads. The authors further show that the expansion of missions in Gold Cost was done mostly by locals -rather than Europeans. The authors further show that the politically centralized Ashanti ethnic groups benefited the most, while areas close to the Muslim Belt in the North did not attract missionary schools. Jedwab, Meier zu Selhousen, and Moradi (2017) then show that the long-term association between contemporary education (and development as reflected on luminosity) and Christian missions is much weaker when they carefully condition on the features that have shaped the expansion of missions. A similar pattern applies also to the pan-African sample of Roome (1924). 
South Africa Fourie and Swanepoel (2015) explore persistence in education and examine the role of Christian Missions in the Cape Colony in South Africa, merging the census of missions in 1849 with the 1996 population census. As Jedwab, Meier zu Selhousen, and Moradi (2017), their analysis adds to the literature, as it minimizes error-in-variables. Fourie and Swanepoel (2015), first, show that indigenous residents of districts with a mission in 1849 have on average higher educational attainment. This result is robust to the inclusion of contemporary controls. However, once the authors try to account for selection on the location of missions, controlling for colonial era features, the long-run correlation disappears, suggesting the importance of location-specific omitted variables in driving both the placement of missions and their aftermath.

\subsubsection{Taking Stock and Future Work}

These works have advanced our understanding of the legacy of colonial educational policies and investments. Clearly colonial policies, such as the location and investments of Christian missions, were not random events (Fourie and Swanepoel (2015), Jedwab, Meier zu Selhousen, and Moradi (2017)). As such the major issue of identifying causal effects is still an open question. And there are still open questions regarding the mechanisms at work and potential interactions with other colonial investments (railroads) or precolonial aspects. First, as our understanding of colonial investments deepens building more complete datasets on early human capital and health investments is a natural and necessary step forward. This requires laborious archival work and digitization of scattered sources. Yet, better data will not only improve error-in-variable biases but they are vital to obtain a more analytical overview on the spread of education and Christianity in Africa, an interesting inquiry by itself that relates to religious competition (see Gallego and Woodberry (2010) for a discussion on competition between Protestant and Catholic missions in Africa). The detailed work of Jedwab, Meier zu Selhousen, and Moradi (2017) in Gold Coast, offers an illustration and the fruits of such a painstaking endeavor.

Subsequent research should allow for differences across Protestant missions, as Protestant and even Roman Catholic sects are decentralized and their ideologies and priorities differed (see on this Caicedo (2017) and Waldinger (2017) who allow for differences across Roman Catholic sects in Latin America). Second, we need more colony-specific studies that would allow us to quantify the legacy of colonial educational policies in a similar political and institutional context. Third, it would be interesting to connect colonial (and perhaps also at-independence) policies with the pattern of industrial specialization; perhaps the under-supply of skilled labor can explain Africa's low export share in skill-intensive and complex sectors (e.g., Romalis (2004), Ciccone and Papaioannou (2009), and Nunn (2007)). And future works could integrate some "reduced-form" estimates with quantitative models of international and international trade (e.g., Eaton and Kortum (2002)). Fourth, it would be interesting to distinguish between different types of education and to allow for differences in schooling quality that seems to correlate strongly with economic growth (Hanushek and Kimko (2000)). Fifth, a much unexplored issue regards the role of Islamic 
educational institutions on literacy, social and political development.

\subsection{Infrastructure Investment}

\subsubsection{The Thesis}

Roads and railroads in Africa were largely non-existent at the end of the 19th century. Wheeled transportation was barely used and head porterage was the main means of transportation (Chaves, Engerman, and Robinson (2014)). Africa was the least urbanized continent, having a dearth of cities above 10,000 people, and African kingdoms had not invested much in roads. Possible explanations range from unfavorable geography (rainforests, desert), to the Tsetse fly that prevented the use of draft animals, to the low levels of political centralization necessary for the undertaking of scale-sensitive projects. ${ }^{16}$ This was to change with colonization, at least partially; Europeans' desire to exploit agricultural and mineral-rich areas and control the interior led them to construct railroads and some roads. ${ }^{17}$ Jedwab and Moradi (2016) report that roughly one third of the colonial budgets were devoted to the construction of railroads.

At that time, scholars and policy makers viewed colonial investments in transportation as a major positive influence of colonization for the African economy. Figures 5a-5b map the distribution of railroads in sub-Saharan Africa at the end of the colonial era in 1960 using data from Jedwab and Moradi (2016) (South Africa is excluded). Two interesting patterns emerge. First, at the end of the colonial era, there were few railroads, as investments were limited. Second, the railroads (and roads) did not connect the main African cities; rather railroads connected ports with the interior, as the European strategy was to extract cash crops and minerals. Figure 5b illustrates this pattern, zooming in on Mozambique. In a colony larger in size than France, there were just 3 main and 2 subordinate rail lines. The lines connected the ports of Lourenço Marques, Beira, and Nacala to the interior (namely Johannesburg, Salisbury-Harare, Tete, and Lake Malawi). There was no effort to connect the Southern with the Central and Northern provinces; the colony was effectively split into three zones.

\footnotetext{
${ }^{16}$ Chaves, Engerman, and Robinson (2014) provide a systematic exploration of why wheeled transportation remained limited in sub-Saharan Africa. Their analysis reveals that the economic benefits of roads-railroads and wheeled transportation far exceeded the costs. And ecological (Tsetse fly) and geographic conditions can only partly explain the "puzzle." They argue that the main drivers of the non-adoption of wheeled transportation in precolonial Africa were the overall low levels of political centralization (see below for a detailed discussion) and the opposition from Europeans to share technology being sceptical of "autonomous African modernization."

${ }^{17}$ Okoye, Pongou, and Yokossi (2017) study the role of colonial railroads on contemporary development in Nigeria. Out of the 14 major rail segments, six are classified as having an "administrative and agricultural" objective, two as having "agricultural and mining", and four as having solely an "agricultural" objective. One segment had a "mineral" goal and one had an "administrative and mineral" objective.
} 


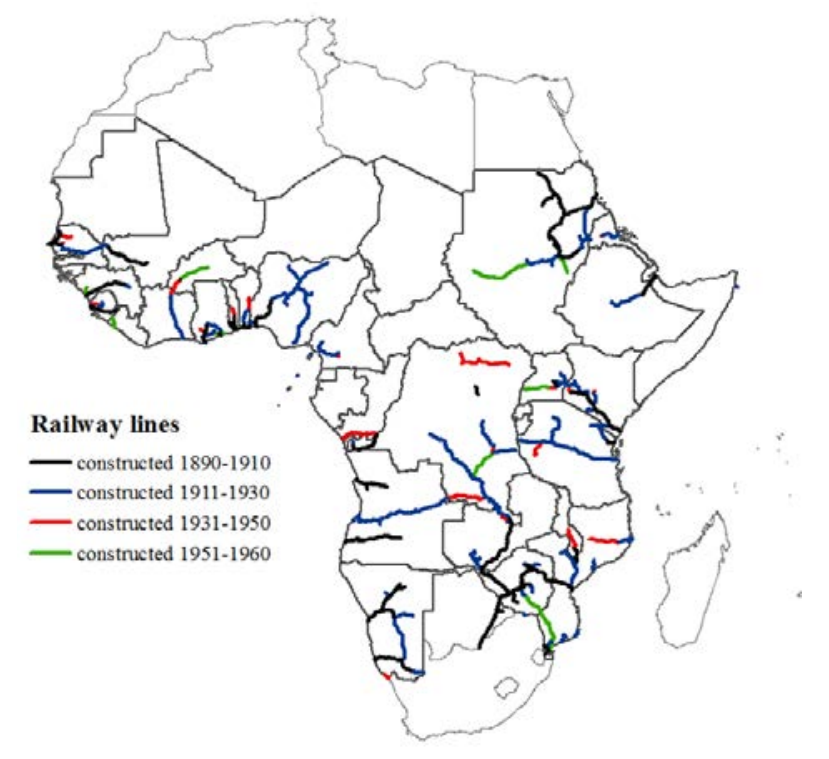

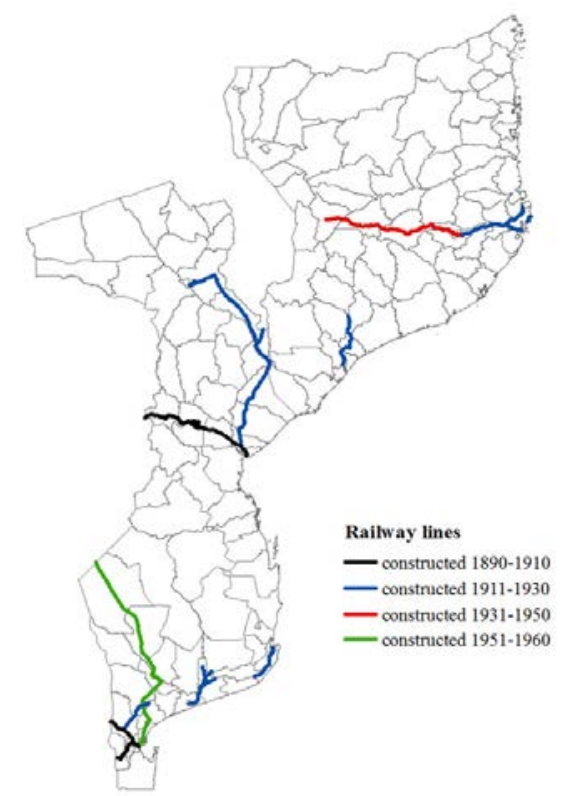

Figure 5a: Colonial Railroads Sub-Saharan Africa Figure 5b: Colonial Railroads in Mozambique

Colonial investments in roads were also limited. And at the end of colonization, there were just a few paved and primary roads. Figure 6a gives the distribution of "paved" and "improved" roads in 1960 across sub-Saharan African countries using data from Jedwab and Storeygard (2017). Figure 6b zooms in on Ghana (the Gold Coast) which had some roads even during the precolonial times.

The importance of infrastructure investment, in roads and railroads, for "Big-Push" style industrialization and structural transformation cannot be overstated (for a review, see Azariadis and Stachurski (2005) and Durlauf and Shaoshadze (2014)). Accessing global markets and promoting trade enables the development of manufacturing and improves productivity in agriculture. Road and railroad investment also facilitates urbanization, which has been linked to the spread of ideas and improvements in the production process (see Glaeser and Gottlieb (2009)). ${ }^{18}$ Jedwab and Storeygard (2017) provide cross-country evidence of a positive link between (improvements in) roads and economic growth during Africa's post-independence

\footnotetext{
${ }^{18}$ Redding and Turner (2015) summarize research revealing considerable and multifaceted positive effects of road and railroad infrastructure on development. Donaldson (2015) reviews works on the impact of market integration on economic performance.
} 
period.

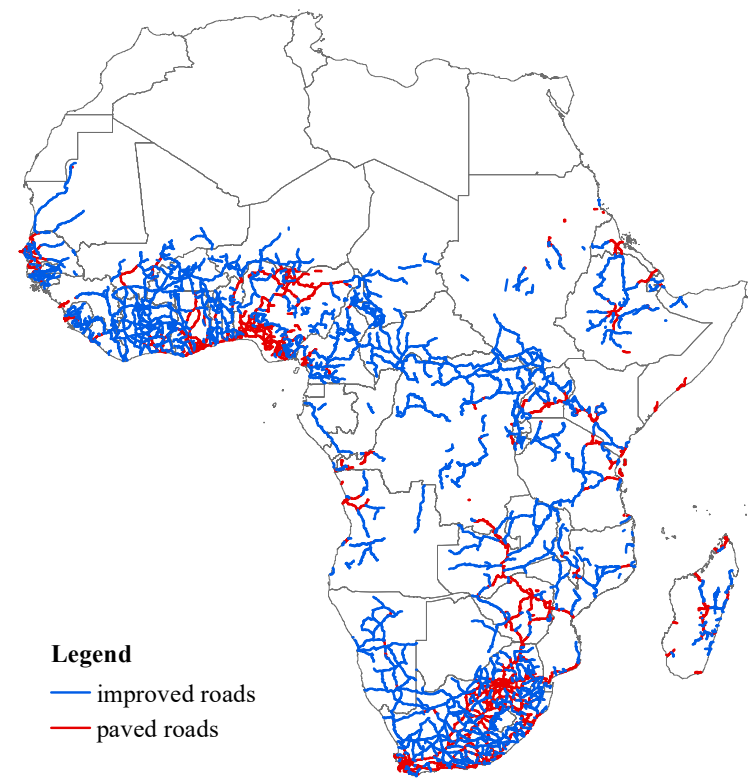

Figure 6a: Roads at Independence

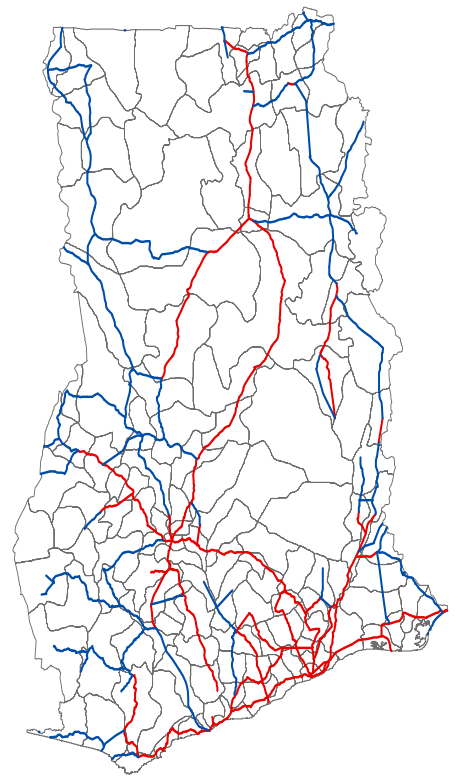

Figure 6b: Roads in Ghana in 1960

\subsubsection{Evidence}

Recent studies examine the legacy of colonial investments in roads and railroads using micro-level data in various contexts.

Kenya Kerby, Jedwab, and Moradi (2017) quantify colonial railroads' impact on Kenya's postindependence development path. They first show that the Lunatic Express line connecting Mombasa to Lake Victoria in Uganda was instrumental in the development of colonial cities/towns. Europeans and Asians settled in areas close to the colonial rail line and developed commercial farms. Second, Kerby, Jedwab, and Moradi (2017) show that the spatial equilibrium of economic activity persisted after independence; this is interesting, as many European and Asian settlers were forced to leave the country in the 1960s and colonial railroads declined due to mismanagement, under-maintenance, and the development of roads. Third, they show that path dependence and spatial coordination may explain the strong inertia. The combination of Kenya's low population density before colonization and the largely idiosyncratic nature of the Lunatic Express assuage endogeneity concerns.

Gold Coast Jedwab and Moradi (2016) examine the role of the two colonial railroads in the Gold Coast (Ghana); the West line was built at the turn of the 20th century $(1898-1903)$ to serve the gold fields of Tarkwa and Obuasi; it also had a military objective, as the British administration wanted to be in a position to dispatch soldiers to the Ashanti area. The construction of the East line started in 1908, reaching Tafo in 1918 and Kumasi in 1923, targeting not only gold-rich areas, but also cocoa-producing regions. Thanks to the development of the two railroads, Ghana became the largest global producer of 
cocoa by 1931. Urbanization increased in the areas close to the rail lines; as cocoa production is labor intensive and wages were rising, people flocked in response to growing economic opportunities. The colonial spatial equilibrium outlived Ghana's independence with today's urbanization, services, and manufacturing being significantly higher in areas close to the railroads. Jedwab and Moradi (2016) perform various tests to assuage concerns that the estimates reflect other factors or strategic placement. They compare areas close to the constructed railroads with areas close to planned rail lines that were eventually not built. They also compare nearby (treatment and control) cells that have similar geographic and other characteristics. Finally, they restrict estimation to the Western line that was built for reasons unrelated to cocoa production.

Nigeria Okoye, Pongou, and Yokossi (2017) examine the contemporary impact of colonial railroads in Nigeria using data from the DHS. Their analysis yields two main findings. First, controlling for individual and location characteristics (as well as state fixed effects), respondents residing close to the colonial railroads (within 20 kilometers) have, on average, higher literacy and educational attainment, and are more likely to read newspapers, watch TV, and listen to the radio. At the same time, they are more likely to work in professional services, live in better houses, and enjoy access to relatively more public goods. In line with the evidence of Jedwab and Moradi (2016) and Kerby, Jedwab, and Moradi (2017) in Ghana and Kenya, the analysis further uncovers higher urbanization rates close to colonial railroads. To improve on identification, Okoye, Pongou, and Yokossi (2017) compare households close to actual and placebo rail lines (planned but not constructed) and also use as an instrument the geodesic distance connecting the main nodes. Second, the impact of colonial railroads appears quite heterogeneous, being strong in northern provinces and nil in the South; the authors argue that the introduction of railroads benefited isolated areas (with initially high transportation costs), while its impact in Southern towns that were already connected via some roads to the ports was muted (as their transportation costs were already low).

South Africa Herranz-Loncan and Fourie (2017) study that the impact of the rail in the Cape colony in late 19th-early 20th century. The railroads were funded by the local administration to promote development; the rail lines connected the main ports and farming districts initially with the diamond mines in Kimberly and then with the Witwatersrand goldfields in neighboring Transvaal. Their analysis shows that the impact of the railroads was considerable; connecting Cape Town (as well as Port Elizabeth, Port Alfred and East London) to the interior explains a bit less than the sizable growth of the colony between 1870 and 1909 that was around 4.8\%. Herranz-Loncan and Fourie (2017) further show that the gains were unequally spread, with economic activity in non-rail-connected areas falling, contributing to the vast regional inequalities.

Ethiopia Bertazzini (2018) examines the local effects of the roads that the Italians built in Ethiopia, Somaliland, and Eritrea from 1934 til 1940. He first shows that population density, luminosity, 
and other proxies of well-being are significantly higher in proximate to colonial roads areas today. To advance on causality, he runs placebos using planned roads that were not built because of the World War. When he digs into the mechanisms, he finds that colonial roads affected population density in 1940 which through agglomeration dynamics shaped contemporary urbanization and development. This is an interesting study both because there is not much research on Italian colonial rule and because it focuses on roads, rather than railroads.

Pan-African Results While the case studies are useful in understanding the context, identifying the potential mechanisms at play, and probing causation, a natural question regards generalizability. Working on a sample of 39 sub-Saharan African countries, Jedwab and Moradi (2016) show that the spur of African urbanization post-independence is also related to colonial railroads. In ongoing work, Alesina, Hohmann, Michalopoulos, and Papaioannou (2018b) uncover a robust positive link between proximity to colonial railroads (and roads) to educational attainment, using census data from 23 African countries. They further show that the impact is quite persistent; it is strong for the cohorts born before and after independence. They also show that proximity to colonial railroads is related to intergenerational mobility in education, thus identifying a channel of persistence.

\subsubsection{Future Work}

There are a few open areas for research. First, future research should move beyond estimating local effects and quantify the economy-wide impact of colonial investments. Building on the important work of Donaldson (2018) on the impact of colonial railroads in India and other related works (e.g., Donaldson and Hornbeck (2016), Perez-Cervantes (2014), and Alder (2015)), future research could apply a "market access" approach based on a general equilibrium trade theory of comparative advantage (Eaton and Kortum (2002)) that looks quite suitable to Africa's context, and estimate both the direct and indirect effects of road-railroad infrastructure.

Second, subsequent research could use comparable data across African countries (from DHS, Censuses, or satellite imagery) to estimate the impact of colonial railroads and roads across the continent (as Jedwab and Storeygard (2016) try to do). Third, a largely unexplored area is linking colonial road-railroad investments to state capacity that is evidently lacking in Africa (see Hunziker, Muller-Crepon, and Cederman (2018) for some recent evidence in this direction). Fourth, research could assess the impact of other than railroad-road infrastructure investments, for example dams, electricity power grids, ports, and airports. ${ }^{19}$ Finally, a more pertinent avenue to enrich our understanding of the impact of colonial transportation infrastructure on Africa's economic growth is to carefully think of the optimal counterfactual transportation network that could have come into existence under different scenarios.

\footnotetext{
${ }^{19}$ Tischler (2013) and Miescher (2018) provide illustrative case studies on the construction of dams in Central Africa and Ghana, respectively, which epitomized nations' effort of "modernization".
} 


\subsection{Colonial Legacies and African Development: Looking into the Future}

The works reviewed above showcase the exciting work that is being done to uncover the multifaceted colonial legacy on African development. They range from meticulous case studies to Pan-African explorations. These works move beyond the very coarse-macro debates on whether the colonial origins of comparative development stem from institutions, human capital or/and infrastructure investments, cultural norms, or state artificiality attempting to shed light in particular contexts and looking at well-defined "shocks/interventions".

We believe that more archival and historical work is needed. For example, a robust codification of "indirect-rule" experiences across groups is clearly missing (see Lange (2009) for an early attempt); the dichotomy between Protestant and Catholic missions masks a great deal of within-denomination heterogeneity; the mission's literature does not distinguish between early stations with a significant European presence and subsequent stations where locals took the lead; and there is a multitude of colonial concessions granted during the colonial era that await investigation.

In their attempt to credibly identify the phenomenon under investigation, most studies look at cases where the colonial "treatment" took one form or the other. However, the colonial experience looks more like a "bundle treatment"; so studying particular aspects, while useful, is likely to obscure the interplay between different heritages and interventions. Circling back to the inquiry of quantifying the colonial experiment, the elusive question of understanding the evolution of African society and economy in absence of colonization should be engaged with.

\section{The Scramble for Africa}

The Scramble for Africa is a milestone in Africa's history; between roughly 1880 and 1905, European powers partitioned the largely unexplored interior of the continent into colonies, protectorates, special zones, and free-trade-areas". The boundaries, drawn upon imprecise maps in European capitals with minimal understanding of local geography and ethnic landscape, were not meant to delineate independent states. Nevertheless, they endured African independence. Even, the administrative borders of the gigantic L'AEF (Afrique équatoriale française) and L'AOF (Afrique occidentale française) persisted. Works in political science, history and international security argue that the most consequential impact of European's involvement in Africa was not colonization per se, but the erratic border design that took place when Europeans "discovered" Africa (Herbst (2000), Asiwaju (1985)). Motivated by these conjectures, recent studies identify a significant impact of Africa's Scramble on contemporary development.

Broadly speaking there are two lines of research. The first centers its attention on the partitioning of ethnicities across the colonial-national border. Approximately a third of historical homelands straddle more than one contemporary countries, with 30\% - 40\% of Africans belonging to these groups (Alesina, Easterly, and Matuszeski (2011), Asiwaju (1985), Michalopoulos and Papaioannou (2016)). Anecdotally, 
ethnic partitioning has been linked to civil conflict, irredentist demands, and discrimination (e.g., Dowden (2008)). The second line focuses on the creation of large, arbitrarily-shaped, with little internal cohesion, states. For example, Africa has the largest share of landlocked countries across continents (30\%), a feature that has impeded development by limiting countries' access to international markets and curtailing trade potential. These exogenously imposed physical and social attributes (related among others to the level of ethnolinguistic fractionalization) have stark consequences for state capacity and the quality of governance.

In this Section, we first provide a synopsis of the Scramble for Africa and discuss the main explanations for the hasty partitioning of the continent. We then discuss works detailing its aftermath, distinguishing between the two broad sets of aforementioned channels.

\subsection{Historical Overview ${ }^{20}$}

\subsubsection{Colonial Border Design}

The partitioning of Africa starts around 1875 and lasts for roughly 40 years. ${ }^{21}$ Wesseling (1996), Pakenham (1991), Thomson (2010), Chamberlain (2013) and Meredith (2005) provide detailed narratives. During 1860 - 1914, Europeans signed hundreds of bilateral and multilateral agreements splitting the continent. Most agreements followed unilateral declarations of occupation. For example, the British annexed Lagos in 1861 raising claims for the hinterland of Nigeria. In 1866, France claimed the Guinea Coast, while in 1893 it "acquired" Ivory Coast. In July of 1884 Gustav Nachtigal, acting on behalf of Bismarck, hoisted German flags in Togo and Cameroon. In some cases, there were (dubious) "treaties" between European explorers, representatives, and local chiefs-kings. On behalf of King Leopold II, Henry Morton Stanley managed to secure treaties with locals (in 1881 - 1882) that would serve Leopold's grandiose plans in Congo. The event that came to symbolize the partitioning of Africa was the Conference that Otto von Bismarck hosted in Berlin from November 1884 to February 1885; while the Berlin conference dealt mostly with Central Africa (Congo), it laid down the principles that would be used among Europeans to divide the continent. ${ }^{22}$ Because of this it came to epitomize the European colonization of Africa.

\footnotetext{
${ }^{20}$ This subsection draws on Michalopoulos and Papaioannou (2016a, b). Wesseling (1996), Pakenham (1991), and Asiwaju (1985) provide detailed narratives of the Scramble for Africa and the drawing of colonial boundaries. Pakenham (1991) discusses all main treaties and gives a detailed chronology of the partitioning of the continent and the establishment of colonies and protectorates. Brownlie (1979) provides a detailed overview of the legal treaties shaping African boundaries.

${ }^{21}$ The colonization of South Africa (Cape colony) started way earlier in 1652 by Dutch and subsequently British settlers.

${ }^{22}$ Three major principles regarding the partitioning of the continent emerged from the Berlin Conference (Wesseling (1996)). First, according to the "hinterland doctrine" a colonial power claiming the coast had also a right to its interior. A good example of is Gambia, which is just a land sliver surrounding Gambia River. The British Crown Colony, established in 1889, covered only the area around the coastline and capital Banjul, and the hinterland was administered separately, as a British protectorate. Second, the principle of "effective possession" required Europeans to base their claims on treaties with local chiefs and kings, something however that was perhaps very easily done. Third, the "effective occupation" principle required that European powers exert significant control of the territory they were claiming. Upon British insistence, this principle was soon diminished to apply to the coastline.
} 


\subsubsection{From Colonial to National Borders}

Following World War II, the revolutionary movements spread across the continent precipitating the end of the colonial era. ${ }^{23}$ While the independence movements pursued different strategies of varying success, soon it became apparent that decolonization was inevitable. Independence of North Africa takes place in the 1950s (Libya in 1951, Morocco and Tunisia in 1956), and then spreads south. Ghana's and Guinea's independence in 1957 and in 1958 are followed by most Sub-Saharan countries in the 1960s. Decolonization is complete by 1974 - 1975, when former Portuguese colonies (Mozambique, Angola, Guinea-Bissau, and Cape Verde) become sovereign states after the fall of the military dictatorship in Lisbon. [Probably the colonial experiment concludes in 1994 with the first post-apartheid democratic elections in South Africa.]

The anti-imperialist agenda of the newly-minted states, the Pan-Africanism ideology, and the reluctance of departing Europeans to deal with the issue of borders, muffled voices for a comprehensive border realignment. So, with a handful of exceptions, African countries accepted the colonial administrative borders in the founding chapter of the Organization of the African Union (OAU) in $1963-4$. Not only the borders separating French, British, Portuguese, and Belgian colonies persisted, but also the ones delineating administrative regions of French West and Equatorial Africa. ${ }^{24}$ Somalia objected, due to the partitioning of the Somali clans across the Italian, British, and French Somaliland, as well as Northern Kenya and Eastern Ethiopia. Morocco also didn't accept the borders with Western Sahara and Algeria; these disputes resulted in the so-called Sand War in 1963 and ongoing tensions. There were some smallerscale disputes and objections, for example, from Ghana and Togo regarding their border that splits the Ewe, a large ethnic group, though the border did not change.

\subsubsection{Border Arbitrariness}

While conspiracy theories abound, a careful reading of the archives and historical accords reveals an idiosyncratic - rather than an intentional- making of colonial artifacts. Asiwaju (1985) writes that "the study of European archives supports the accidental rather than a conspiratorial theory of the marking of African boundaries." British four-times prime minister, Lord Cecil Salisbury put it bluntly in 1890: "We have been engaged in drawing lines upon maps where no white man's feet have ever trod; we have been giving away mountains and rivers and lakes to each other, only hindered by the small impediment that we never knew exactly where the mountains and rivers and lakes were."

There are several explanations for the serendipitous colony design. To start with, Europeans had limited knowledge of local conditions, as with the exception of few coastal areas, the continent was unexplored. ${ }^{25}$ Europeans were in such a rush to partition the continent that they did not even wait for the

\footnotetext{
${ }^{23}$ Wantchekon and Garcia-Ponce (2014) provide a thorough overview of independence movements and link them to postindependence political development. See Cooper (2002) and Mamdani (1996) for narratives.

${ }^{24}$ In some instances protectorates and colonial administrations merged forming independent countries. For example, Ghana consists of the British-ruled Gold Coast colony, the Ashante Region and the Northern Territories.

${ }^{25} \mathrm{An}$ illustrative example is the annexation of the Katanga region in Congo Free State that turned out to be its richest
} 
explorers' and missionaries' reports. Even in cases where Europeans realized that valuable resources were on the other side of the border or that large ethnic groups were split, they refused to open the border issue. It should also be kept in mind that at the time Europeans were not drawing borders of prospective states. And colonial borders were porous and locals could easily cross them; this partly explains the limited resistance, as little changed on the ground. ${ }^{26}$ So, while in occasions, Europeans did have knowledge of local geographic and political conditions and in some cases tried to respect local political topography (e.g., Swaziland, Rwanda, and Lesotho), in the overwhelming majority such considerations were marginal.

In line with the historical narrative, Alesina, Easterly, and Matuszeski (2011) document that Africa has the highest share of straight-line like borders (around 80\%), compared to other continents. Asiwaju (1985) lists partitioned ethnic groups across almost all African borders. Michalopoulos and Papaioannou (2016) provide indirect evidence on border artificiality: split and non-split ethnic regions are comparable across numerous geographic and ecological characteristics, and there are no major differences between partitioned and non-split ethnicities with respect to various societal, institutional, and economic traits.

\subsection{Rationalizing the Rush of European Colonization in Africa}

There has been a lively debate on the motives of European's rush to colonize Africa in the late 19th century (see Bolt (2013)). Marxists viewed the Scramble for Africa as the inevitable impulse of capitalism to seek new markets and investment opportunities as the return on capital in Europe and the Americas started falling. Commercial motives were also important, as Europeans wanted to secure trade routes to India and Indochina. Imperialist-type explanations stress the prestige and political benefits associated with overseas territories. $^{27}$ Other explanations are of a strategic (balance of power) nature; after long-lasting European wars, Africa became the "battlefield" for Europeans, especially because Asia, Oceania, and South America were already colonized. For example, Bismarck, who was not fond of colonialism but wanted to preserve the status quo, claimed large territories in Africa mostly to counterbalance the influence of France and England. Likewise, King Leopold's Congo Free State was the result of a stalemate between France and Great Britain in their split of Central Africa.

Economic theories on Africa's Scramble stress the impact of two interrelated events: the abolition of slavery and the increased demand for raw materials thanks to the Industrial Revolution. ${ }^{28}$ Initially the slave trades and the high demand of labour in the Americas limited Africa's potential in agriculture. However,

province. King Leopold got Katanga in exchange for the Niari-Kwilu area that the French insisted on getting themselves. Wesseling (1996) writes "what impelled him [Leopold] was a general imperialist surge, the desire for compensation for the Niari-Kwilu, and the objective of making the new state as large as possible and filling as much of the Congo basin as possible."

${ }^{26}$ Asiwaju (1985) cites a Ketu king, saying that "we regard the boundary (between Benin-Dahomey and Nigeria) separating the English and the French, not the Yoruba."

${ }^{27}$ Disraeli put it as follows: "The colonies are millstones round our necks." Likewise Lord Rosebery argued: "That greater pride in Empire which is called Imperialism. . is a larger patriotism."

${ }^{28}$ Austen (1987) provides details on the interplay between African and external development on Africa's division in the late 19th century. Koponen (1994) discusses the role of industrialization on the exploitation of Tanzania during the initial phase of colonization. 
the spread of liberal ideas and the associated abolition of slavery in the early-to-mid 19th century allowed the development of labor-intensive agricultural production. At the same time, industrialization in North America and Europe raised the demand for industrial inputs and minerals. These developments pushed Europeans to colonize Africa, which would soon provide rubber, cotton, and copper alongside agricultural products like palm oil, coffee, and nuts. Frankema, Williamson, and Woltjer (2017) document that the net barter terms of trade for sub-Saharan Africa increased massively from 1845 until 1885; the peak coincides with the Berlin conference of $1884-1885$.

Bolt (2013) lists some additional reasons behind European's rush to explore the continent. Technological innovations in iron metallurgy (better and cheaper weapons) and health (quinine and anti-malarial drugs in 1840; anti-mosquito campaigns in 1901 - 1902), and the steam-engine boat that allowed, for example, the exploration (and exploitation) of the Congo basin and the transportation of minerals and agricultural goods across the Indian and Atlantic Oceans (see Pascali (2017) for empirical evidence on the impact of the steam boat on incomes during the late 19th and early 20th centuries). Technology also improved administrative capacity, allowing Europeans to rule the vast African interior.

\subsection{Mechanisms and Case Studies}

A major consequence of the Scramble for Africa has been the partitioning of many ethnicities across more than one colony-protectorate and post-independence country. The literature has put forward several explanations on how the partitioning of ethnicities and the creation of artificial states has contributed to African underdevelopment.

Irredentism and Foreign Interventions First, in some instances partitioning has generated irredentist demands, as ethnicities that are minority groups in a country want to unify with their peers across the border. Such an example is Somalia. During the late phase of Africa's colonization, Somali ethnicities were split among four colonial powers, while Ethiopia got the Ogaden region that is predominantly inhabited by Somalis. The five-edged star in the Somali flag represents this five-way split along with the desire of the Somali to unite into a single state. ${ }^{29}$ While the British and Italian Somalilands merged in the 1960s, Somali clans in Djibouti (Former French Somaliland), the Ogaden, and the North-Eastern province of Kenya were not allowed to join despite their expressed will. Three-to-five long-lasting wars have been (partly at least) driven by the desire of Somalis in Ethiopia, Djibouti, and Kenya to become part of Somalia (see Meredith (2005)).

Autonomy Second, partitioned ethnicities sometimes fight to obtain autonomy (or even independence). Wimmer, Cederman, and Min (2009) estimate that around $20 \%$ of all civil wars in Africa have

\footnotetext{
${ }^{29}$ Somalia is one of the few African states that did not recognize the colonial borders. At the 1963 Pan-African summit it was argued that "Somali people are members of a single Somali nation. Somali is our language, spoken from the Gulf of Aden to the Northern Frontier District [of Kenya]. Islam is our culture, pastoralism our way of life. We want to reunite with our brothers with whom we can evolve an administration suited to our way of life" (Ajala, taken from Boyd (1979)).
} 
a secessionist component. An illustrative example is the recurring conflict in the Casamance region in Southern Senegal, where the partitioned Diola (Jola) reside. As Gambia effectively splits Senegal into a northern and a southern part, Casamance is disconnected from Dakar. The independence "Movement of the Democratic Forces of Casamance" was supported by the neighboring Guinea-Bissau (and to a lesser extent by Gambia), where the Diola exert a significant influence (see Humphreys and Mohamed (2005) for a narrative of the conflict and the role of colonial boundaries). ${ }^{30}$

Border Imprecision Third, colonial and national borders were poorly delineated; colonial treaties were often imprecise and, while demarcation committees were formed, they proved ineffective. This has resulted in border disputes. Englebert, Tarango, and Carter (2002) write, "of all the territorial disputes brought before the International Court of Justice since 1960, 57\% were African, while only $33 \%$ (104 out of 315) of all bilateral boundaries worldwide are in Africa." This imprecision seems to have contributed to conflict in Somalia (see Samatar (1985)), whereas the ambiguity of the tripartite treaty of 1902 between Britain, Italy and Ethiopia has also played a role in the Eritrea-Ethiopia war.

Ethnic-Based Discrimination Fourth, Africa is characterized by patronage politics, in which dominant ethnic groups often discriminate against minority groups (see Posner (2005) for an overview of ethnic favoritism). In the case of partitioned groups, the neighboring country may intervene either to support its peers or to prevent migration/refugee flows. For example, the Ewe in Togo helped Flt.-Lt. Jerry Rawlings (half Ewe) in his coup in 1979 and 1981 to overthrow the government in Ghana. This escalated ethnic tensions between the Ewe, the Ashanti, and the Akan, leading to a small-scale conflict. The conflict in the Alur-land offers another illustration of this type of violence. The Alur were split between the Belgian Congo and the British Protectorate of Uganda. After independence, when the regime of Mobutu Sese Seko initiated the subjugation of many minority groups in Congo, a large fraction of the Alur moved to Uganda. This in turn generated opposition from the Buganda (the main group in Uganda), leading to ethnic violence.

Crime Fifth, due to the poor institutional infrastructure and their ethnic contacts across the border, partitioned ethnicities engaged in smuggling and other criminal activities. For example, in his analysis of the Anglo-French partitioning of the Sultanate of the Mandara in the Nigeria-Cameroon boundary, Barkindo (1985) writes that "the most serious problem was the increase in crime and disputes across the border. The fact that the border divided people of the same family and settlements made it difficult to check crime and control smuggling." Collins (1985) also provides an illustration of how smuggling allowed the Hausa to arbitrage price caps and other distortionary policies in Niger and Nigeria.

\footnotetext{
${ }^{30}$ Renner (1985) writes, "Senegal itself became truncated, and could only be linked by traversing Gambia or by using the much lengthier overland route. The partition was undertaken (between the French and the British) without any consideration for cultural ties, economic viability or regional coherence."
} 
Trade Sixth, ethnic partitioning could be beneficial, if it promotes cooperation and commerce. Aker, Klein, O'Connell, and Yang (2014) examine agriculture trade at the Niger-Nigeria border. They show that the overall significant border" effect is greatly attenuated for international trade within the partitioned Hausaland. They also show that in Niger transactions are far higher for intra-ethnic trade as compared to interethnic trade, which seems to be quite costly - in some cases costlier than across-thenational-border trade within the same ethnic group. ${ }^{31}$ Similarly, Iwanowsky (2018) finds that bilateral exports are significantly higher in African countries with precolonial ethnic linkages.

Other Seventh, border artificiality could offer an "excuse" for weak authoritarian governments to engage in conflict to get popular support and increase their legitimacy (Touval $(1967,1972)$ ). While in this case the problem is growing dissatisfaction stemming from a recession, crisis, or misgovernance, the presence of partitioned co-ethnics may offer a rationale for conflict.

\subsection{The Legacy of Ethnic Partitioning}

Wesseling (1996) summarizes the partitioning eloquently: "The partition of Africa was recorded by the Europeans on their maps, but the matter rested there for the time being.... In Europe conquests preceded the drawing of maps; in Africa the map was drawn, and then it was decided what was going to happen. These maps did not therefore reflect reality but helped to create it." The applied literature in political science, and more recently in economics, has attempted to quantify the impact of ethnic partitioning on conflict and underdevelopment.

\subsubsection{Cross-Country Data Patterns}

Working on a global sample covering 120 - 135 countries, Alesina, Easterly, and Matuszeski (2011) provide econometric evidence that artificial" states underperform economically compared to organic ones. The authors construct two proxy measures of artificiality: $(i)$ A fractal index, ranging from 0 to 1 , that reflects the straightness-squiggliness of a country's borders. The idea is that the more straight-line like a country's borders are, the more likely it is that they were drawn without much attention to local conditions. (ii) A partitioned index that measures the percent of country's population that belongs to ethnic groups present in two (or more) adjacent countries. ${ }^{32}$ Africa scores the lowest in the fractal index (the mean value is 0.028 for the 44 African countries, while for the rest of the world the mean is 0.041). Differences between African and non-African countries are starker when one examines the share of the country's population that comes from partitioned ethnicities. The African mean (median) is $47 \%$ (39\%), while for non-African countries the mean (median) is $18.2 \%$ (7.8\%). Alesina, Easterly, and Matuszeski (2011) report cross-country regression estimates of a negative association between GDP per capita in 2002 and the population share of partitioned

\footnotetext{
${ }^{31}$ Schultz (2015) reviews works in political science on borders, conflict, and trade.

${ }^{32}$ The correlation of the two proxies of state artificiality in the global sample of 132 countries is small (0.071).
} 
ethnicities; the regressions also reveal a negative link between GDP per capita and border straightness, though the correlation is muted and imprecise.

Ethnic partitioning may hamper economic development by enabling the spread of conflict across the border. In line with this, one observes many internationalized" intrastate wars in Africa, where government troops, rebels, or militias from a neighboring country intervene in their neighbor's civil war. Bosker and de Ree (2014) find that the likelihood of civil war increases when there is a civil war in neighboring nations; this spillover is present only for civil wars with an explicit ethnic dimension. The spillover is strong when people from the same ethnic group reside in the neighboring countries. While this study is not limited to Africa, it points out that ethnic partitioning facilitates the spread of civil war across countries.

\subsubsection{African Border Studies}

In early contributions, Touval (1972) and Boyd (1979) combined narratives with a correlation analysis examining the link between border artificiality and conflict, documenting some large-sample patterns. Englebert, Tarango, and Carter (2002) examine the role of border arbitrariness on cross-country and crossborder conflicts in Africa. In the cross-country part, they show that the percentage of the population that comes from partitioned ethnicities is a significant correlate of civil war; this is especially the case for territorial disputes with an explicitly secessionist dimension. The cross-border analysis shows that disputes are more likely when the two sides of the border are inhabited by people from the same ethnic group. There is also some evidence that conflict is higher in countries with straight-line borders. Goemans and Schultz (2017) also look at territorial disputes using data from the Correlates of War, contemporary ethnic maps, and the ethnic power relations database that records ethnicities' political power (EPR) in national politics (Cederman, Wimmer, and Min (2010), Wimmer, Cederman, and Min (2009), and Vogt, Bormann, Ruegger, Cederman, Hunziker, and Girardin (2015)).). Overall there are 29 disputes across 102 borders. Goemans and Schultz (2017) find that ethnic partitioning increases the likelihood of territorial conflict, but only for ethnic groups that are politically powerful. Territorial claims are more likely when borders are ethnically homogeneous and long. The border (country-dyad) analysis further shows that poor or provisional demarcation increases conflict likelihood, while the presence of rivers, lakes, and water bodies lowers the likelihood.

\subsubsection{Within-Country Regional Evidence}

The cross-country approach is always useful, as it reveals broad data patterns in a transparent manner. Yet, it is always challenging to identify causal mechanisms in such a framework, due to various endogeneityrelated issues (error-in-variables, omitted variables, selection) and the limited degrees of freedom. ${ }^{33}$ In Michalopoulos and Papaioannou (2016), we exploit within-country regional variation in ethnic partitioning,

\footnotetext{
${ }^{33}$ See Hegre and Sambanis (2006) and Ciccone and Jarocinski (2010) for the instability of cross-country civil war and growth correlates to small model's permutations and data revisions. Durlauf (2009) reviews the rise and fall of cross-country growth regressions. See also Durlauf, Johnson, and Temple (2005)
} 
conflict, and public goods to advance on identification and shed light on the mechanisms linking this aspect of the Scramble for Africa to underdevelopment. Our analysis proceeds in four steps.

Ethnic Partitioning First, we overlay contemporary (as of 2001) country borders to George Peter Murdock's Ethnographic Map portraying the spatial distribution of ethnicities in the late 19th and early 20th centuries to identify ethnicities split by the national border. Murdock's map (Figure 7a) delineates 835 ethnic homelands/regions (and eight "uninhabited upon colonization areas"). We classify as partitioned those ethnicities whose homelands have at least $10 \%$ of their landmass in more than one country. There are 229 split ethnicities (27.7\%; Figure $7 \mathrm{~b})$; the number of split ethnic homelands is 266 if one uses a less stringent $5 \%$ cutoff. While there is noise in Murdock's map, related to the accuracy of original information, projection error, and the fact that ethnic groups at least to some extent overlapped, this transparent procedure identifies the major partitioned ethnic groups, as considered by African historians (e.g., Asiwaju (1985)). For example, the Maasai are split between Kenya and Tanzania, the Anyi between Ghana and the Ivory Coast, the Chewa between Mozambique, Malawi, and Zimbabwe, the Ewe between Togo and Ghana, the Ambo between Namibia and Angola, and the Hausa between Niger and Nigeria.

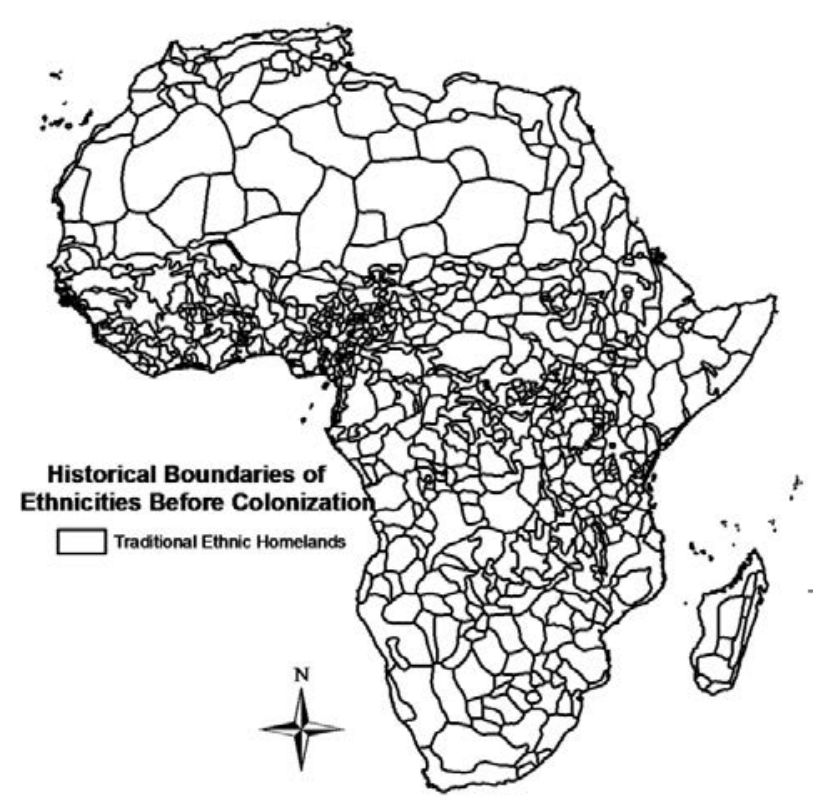

Figure 7a: Murdock's Ethnographic Atlas

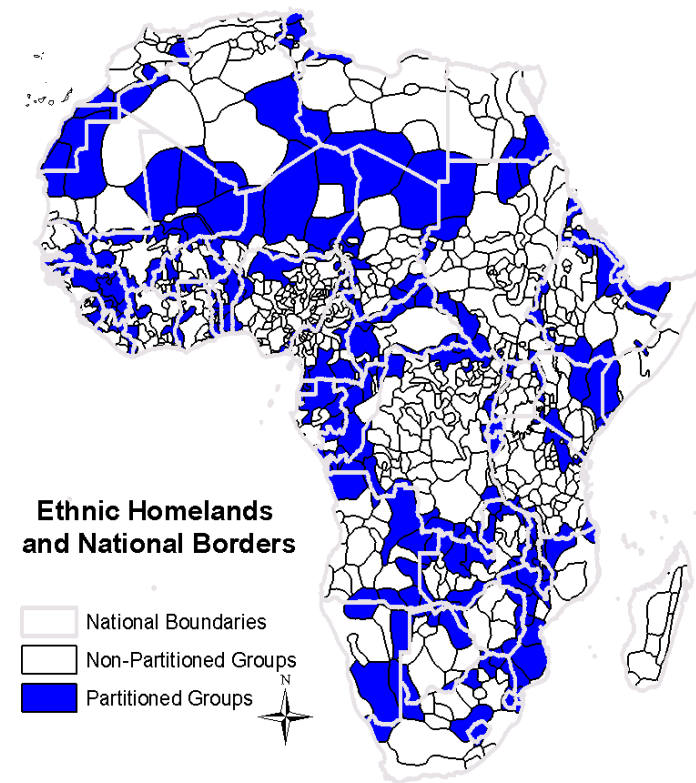

Figure 7b: Partitioned Ethnic Homelands

We then examine whether split and non-split ethnic homelands differ across geographic and ecological characteristics. With the exception of land area there are no major differences. There are also no systematic differences across precolonial, ethnic-specific features, such as the size of settlements, the type of subsistence economy (agriculture, pastoralism), or proxies of precolonial conflict. These results do not necessarily imply that all African borders were drawn with little regard to local conditions; yet, since geographic and precolonial features may affect contemporary conflict, they affirm that the link between partitioning and 
conflict does not capture these traits.

Ethnic Partitioning and Civil Conflict Second, we quantify the impact of ethnic partitioning on civil conflict, as this has been theorized to be the main link. We use data from the Armed Conflict Location \& Event Data Project (ACLED), which reports georeferenced information on battles between government forces, rebels and militias, violence against civilians, foreign interventions, conflicts between non-state actors, and riots/protests. Figure 8a portrays the spatial distribution of violence in Africa from 1997 to 2013 (reported conflict incidence increases considerably after 2010, but this does not affect the results). The map depicts 64,650 high-precision conflict incidents. There is substantial variation both across and, most importantly for the analysis, within countries. We aggregate the conflict data at the country-homeland level (Figure 8b) and then attribute various aspects of conflict to ethnic partitioning, using the conditions of country fixed effects that capture all national features that affect conflict.

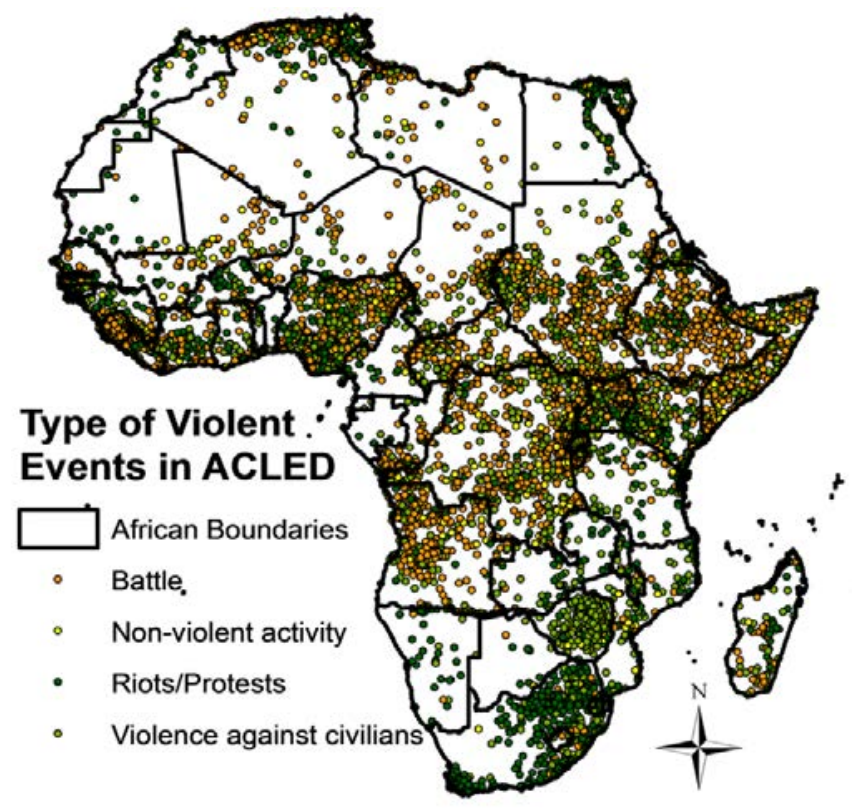

Figure 8a: Civil Conflict in Africa (1997-2013)

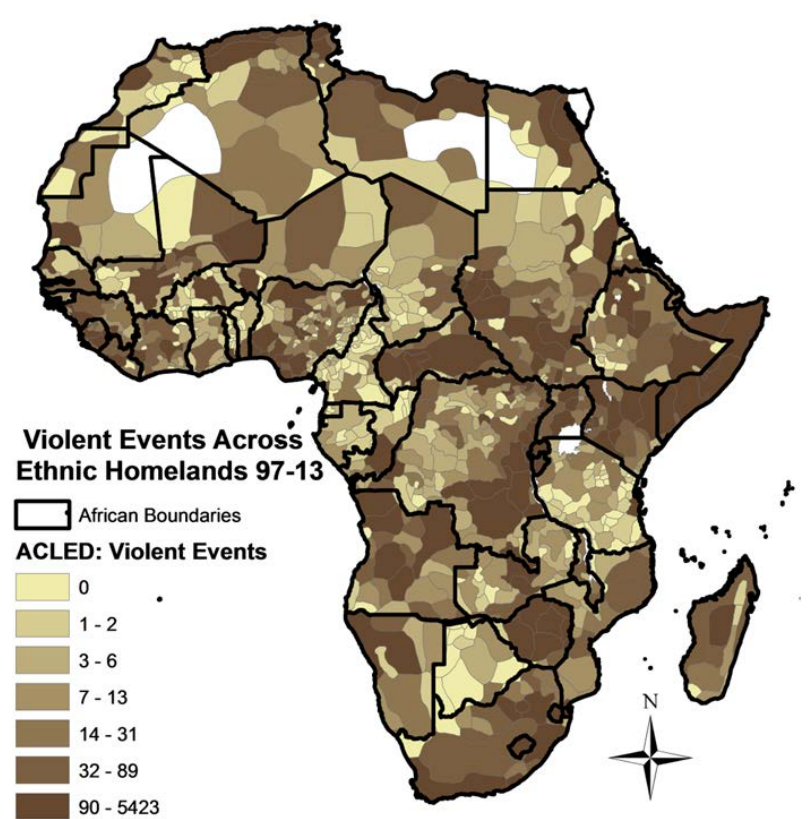

Figure 8b: Civil Conflict across Ethnic Regions

Figure 9 provides an illustration of the mean differences in conflict events between partitioned and non-split groups both in the full sample and in ancestral ethnic regions close to the national border. The econometric analysis, which accounts for country-specific factors and local geographic endowments, reveals that conflict intensity is approximately $40 \%$ higher, conflict duration 50\%-60\% higher, and the likelihood of conflict $8 \%$ higher in the homelands of partitioned groups. The regression analysis reveals significant spillovers, as conflict intensity is $30 \%$ higher and the likelihood of conflict $7 \%$ higher in the homelands surrounded by partitioned groups. ${ }^{34}$ These patterns are present when we restrict estimation to homelands

\footnotetext{
${ }^{34}$ Employing state-of-the-art econometric techniques and high-resolution data, Harari and La Ferrara (2014) show that conflict stemming from weather shocks during crop-growing seasons also spread across space. They also provide some evidence that conflict spills across national borders, especially across ethnic homelands.
} 
close to national borders.

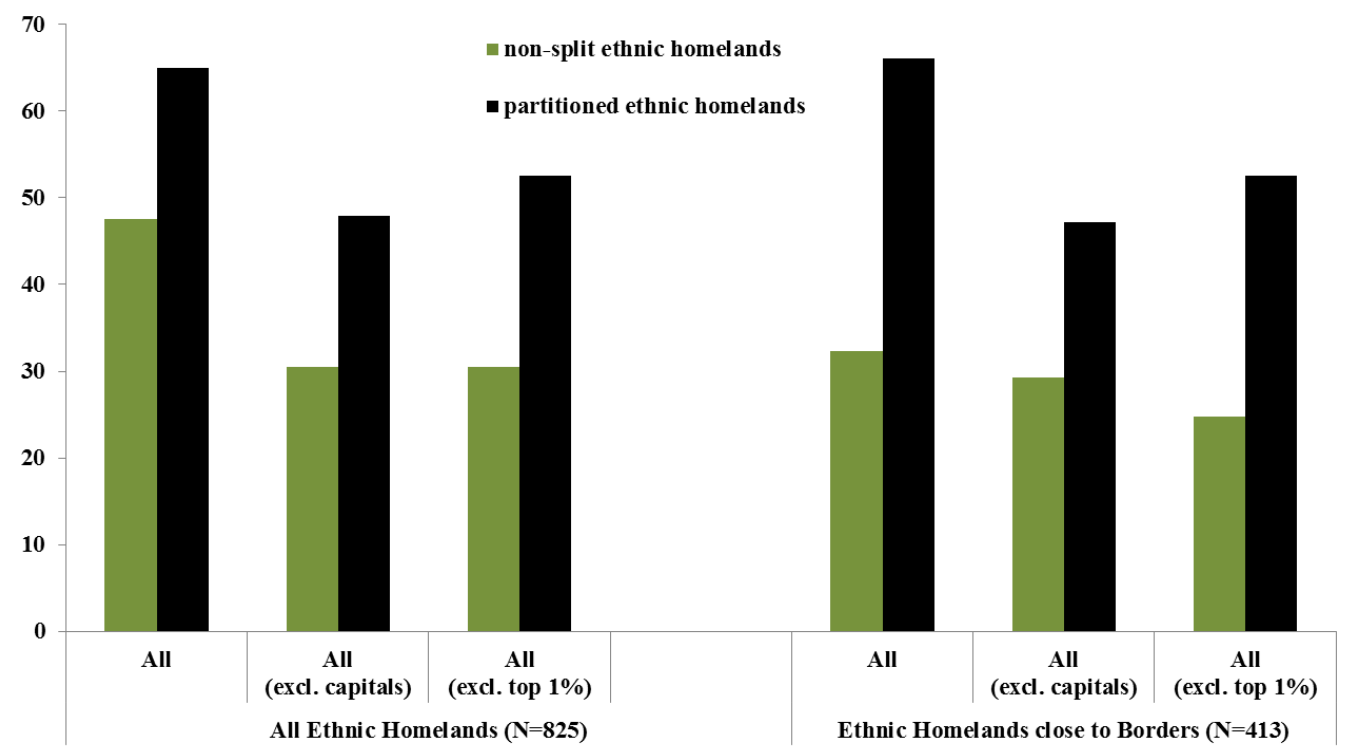

Figure 9: Ethnic Partitioning and Number of Civil Conflict Incidents

We then distinguish between different types of conflict to shed light on mechanisms. Interventions from neighboring countries are more likely to take place in the homelands of partitioned ethnicities, in line with the idea that partitioning acts as a conduit for the spread of conflict across the porous borders of weakly institutionalized African countries. Moreover, partitioning contributes mostly to conflict between government forces and rebel groups whose goal is to "counter an established national governing regime by violent acts" and to a lesser extent with violence against civilians. And we corroborate these results with the Uppsala Conflict Data Program Geo-referenced Event Dataset (UCDP-GED), which records only deadly events associated with major civil wars since $1989 .{ }^{35}$

Ethnic Partitioning, Repression, and Ethnic Wars Third, we delve into the partitioning - repression - civil war nexus using the Ethnic Power Relations database, which provides an assessment of ethnicities' de facto political power in national politics since independence (Vogt, Bormann, Ruegger, Cederman, Hunziker, and Girardin (2015)). Partitioned ethnicities face an 11\% - 14\% higher likelihood of participating in ethnic civil wars. Of the split groups, 72 of 234 (31\%) have participated in an ethnic-based civil war, while 69 out of the 359 non-split groups (19\%) have participated in an ethnic war. The likelihood that split ethnicities are subject to discrimination from the national government is approximately 7 percentage

\footnotetext{
${ }^{35}$ Bazzi and Gudgeon (2017) show that the redistricting of Indonesian municipalities, which allowed regions formerly partitioned across administrative lines to be part of the same district, was followed by a fall in conflict. Using panel data regressions, in a global sample of ethnic groups from 1886 til 2010, Cederman, Rueger, and Schvitz (2018) show that lost of unity and ethnic-specific territorial fragmentation (in more than one countries) is associated with a significantly higher likelihood of conflict.
} 
points higher compared to non-split groups. When we jointly examine the impact of partitioning on onesided violence (repression) and two-sided violence (civil war), we find that ethnic partitioning, rather than political discrimination, leads more often to major conflict.

Ethnic Partitioning and Public Goods Provision Fourth, we examine the role of ethnic partitioning on public goods using DHS data covering close to 85, 000 households across 20 African countries. Individuals who self-identify with partitioned ethnicities have fewer household assets, poorer access to utilities, and worse educational outcomes as compared to respondents from non-split ethnicities in the same country (and even in the same town/village). This pattern is not due to a generalized decline in standards of living of households residing in split homelands - rather, it is driven by the poorer economic performance of members of split ethnicities irrespective of their actual residence.

\subsection{Country-Level Characteristics}

\subsubsection{Landlocked}

Africa's Scramble led to the creation of countries without access to the coast. Of the 49 continental countries, 16 are landlocked: Mali, Burkina Faso, Chad, Niger, the Central African Republic, Ethiopia, Burundi, Rwanda, Malawi, Zambia, Zimbabwe, Botswana, Lesotho, Swaziland, Uganda, and recently South Sudan. One could also add the Democratic Republic of Congo (DRC), the largest African country in terms of land area, which is connected to the Atlantic coast via a tiny 30 kilometer strip. Around 300 million Africans (400 if we include the DRC) live in landlocked countries. In the latter, average per capita GDP in 2007 was 1, 822 USD lower than countries with access to the sea (median differences are roughly 800 USD). A simple regression of $\log$ GDP per capita. on an indicator of landlocked countries yields a highly significant negative coefficient $(-0.80$; standardized beta coefficient -0.35$)$, explaining $10 \%$ of the in-sample variance. ${ }^{36}$ And if one controls for the impact of the slave trades that attenuates landlocked's impact (Nunn and Puga (2012)), the coefficient increases in absolute size $(-1.05$, "beta" of $-0.45 ; t$-stat exceeding 4). Collier (2007), synthesizing a large body of literature, has argued that being landlocked increases the likelihood that the country will be subject to poverty trap" dynamics due to an array of increased costs.

First, transportation costs and the time needed to ship goods are higher for landlocked countries which on average engage less in international trade (see Arvis, Raballand, and Marteau (2007) for an overview of the literature on landlocked countries and trade). Being landlocked is quite detrimental, as inter-city intra-country transportation costs are high. ${ }^{37}$ Second, landlocked countries that depend extensively on their neighbors for their transactions with international markets are also impacted by the

\footnotetext{
${ }^{36}$ Simply adding regional indicators distinguishing between eastern, western, southern, northern, and central African countries, as seen in Nunn (2008), yields larger estimates. The (standardized) coefficient of the landlocked dummy is 0.95 (0.40).

${ }^{37}$ Storeygard (2015) calculates large short-run costs of transportation stemming from the world rise of oil prices in 2002-2007; Atkin and Donaldson (2017) estimate the high "distance" costs of trading goods within Ethiopia and Nigeria.
} 
instability of their neighbors. For example, a large chunk of Zimbabwe's exports are channeled via the Beira corridor and port in the Indian Ocean. During the Mozambican civil war (1977-1992), access to Beira was severely limited or shut down altogether. Likewise, almost all of Ugandan exports to the rest of the world and imports are channeled via the port of Mombasa in Kenya. The so-called Lunatic Express, connecting Mombasa to Uganda's interior, has been blocked on many occasions by protests and riots. Third, Frankema and van Waijenburg (2014) argue that state capacity of the colonial state dissipated far from the coast; they present cross-colony and cross-country patterns showing a much lower state capacity (as proxied by tax yields) in landlocked areas, a pattern that applies both to French- and British-administrated territories.

\subsubsection{Size and Shape}

Theory models the trade-offs between country size, related to the benefits of trade and specialization, and the costs of heterogeneity, mostly related to the under-provision of public goods (see Alesina and Spolaore (2003) for an overview). However, all the evidence makes clear that Europeans paid little attention to such issues during Africa's Scramble.

Herbst (2000) argues that a damaging aspect of the Scramble for Africa was the creation of states with peculiar sizes, shapes, and unfavorable geography. At the core of his argument is the limited state capacity of African countries that prevents them from broadcasting power outside their capitals. ${ }^{38}$ He lists 10 countries with "difficult" political geographies that make it challenging for the state authority to reach its citizens (Angola, Ethiopia, Namibia, Nigeria, the DRC, Mozambique, Senegal, Tanzania, Somalia, and Sudan). For example, in the DRC there are two main densely populated regions; the area surrounding capital Kinshasa and the area around Goma, thousands of kilometers away. The absurdly large size of the DRC, an accident" resulting from the Scramble for Africa that initially was assigned to King Leopold II of Belgium as private property," coupled with the heterogenous geography and population settlements, has not allowed the development of an efficient state. Another example of improper state design is Senegal; the two main urban hubs, around Dakar and Casamance, are disconnected, as Gambia divides the country. Likewise, Herbst (2000) argues that the inverse J-shape of Somalia and the stripping of Ogaden to Ethiopia prevented the government in Mogadishu from reaching out to the populous Northern province of British Somaliland that has been ruled in an almost independent manner for decades.

In ongoing research, Hunziker, Muller-Crepon, and Cederman (2018) test Herbst's ideas compiling proxies of African states' capacity to broadcast power to ethnic groups using Michelin road data from 1964 until 1990. Their (within country-year) ethnic-group analysis shows that a stronger state access (from the capital to the ethnic region) is associated with a significantly smaller likelihood that the ethnicity will challenge the government; at the same time, when ethnic groups are well-connected with each-other then there is a higher likelihood of coups and challenges to the national authority.

\footnotetext{
${ }^{38}$ Bardhan (2016) summarizes works on state capacity. Migdal (1988) provides a thorough analysis of the importance of state capacity.
} 
Herbst (2000) further argues that building state capacity is challenging for the "hinterland" countries: Chad, Mali, Niger, and Mauritania. These large Saharan countries have low population density in their vast desert hinterlands and small urban communities in the South. Herbst (2000) argues that some African countries face an "opposite" problem: they are too small and their economy is not viable unless they develop strong economic ties with larger neighbors. He cites a report by the Fabian Society arguing that "looking further ahead, Eritrea is certainly not a viable unit on its own. If we are to think in terms of eventual independence, its people can stand no chance unless they link themselves to bigger and more viable neighbors." Protectionist policies (tariffs, import substitution) made things worse (see Bates (1981)), as openness to trade is crucial especially for smaller countries (Ades and Glaeser (1999), Alesina, Spolaore, and Wacziarg (2000), and Alcala and Ciccone (2004)).

\subsubsection{Social Composition and Inequality}

Africa is the most ethnically and linguistically diverse continent. The mean (median) value of the likelihood that two randomly chosen individuals will not be part of the same ethnicity is $63 \%(72.3 \%)$ in the 51 African countries, compared to a non-African global mean-median of around 39\%. Easterly and Levine (1997) attributed most of Africa's growth tragedy during the post-independence period to its high degree of ethnic fractionalization (see also Alesina, Devleeschauwer, Easterly, Kurlat, and Wacziarg (2003), Desmet, Ortuno-Ortin, and Wacziarg (2012), and Habyarimana, Humphreys, Posner, and Weinstein (2009)). ${ }^{39}$ This is due to its geographic heterogeneity (Michalopoulos (2012)), ecological features (Cervellati, Chiovelli, and Esposito (2017)), and deep evolutionary traits (Ashraf and Galor (2013)). The design of colonies has contributed to some extent to African countries' ethnolinguistic (and even religious) composition. People from different ethnic, linguistic, and cultural backgrounds were forced to be part of the same colonial artifact. And while this had no major impact during colonial times, as the colonial administration was responsible for peacekeeping and public goods, it became significant with independence. In spite of the Pan-African ideology, ethnic cleavages became salient in the political arena, feeding into ethnic favoritism, discrimination, and conflict.

\subsubsection{Location of Capitals}

Herbst (2000) emphasizes the inappropriate location of African capitals. He writes: "By 1900, twentyeight of the forty-four colonial capitals were located on the coast, demonstrating the low priority of extending power inland compared to the need for easy communication and transportation links with Europe. Rather systematically, Europeans created capitals that moved power toward the ocean and away from the interior

\footnotetext{
${ }^{39}$ Alesina, Michalopoulos, and Papaioannou (2016) and Baldwin and Huber (2010) stress the role of ethnic inequality on development and public goods provision. See also Robinson (2001) and Chua (2003) for narratives on the negative impact of ethnic inequality on political development in Africa and across the developing world, respectively. Archibong (2018) and Bolt and Hillbom (2016) discuss the colonial origins of the persistent regional and ethnic inequality in Nigeria and Botswana, respectively. Alesina, Hohmann, Michalopoulos, and Papaioannou (2017, 2018) show that sizable differences in intergenertaional mobility in education post-independence are related to colonial investments.
} 
centers of power that Africans had slowly created and that had managed to exert control over parts of their surrounding territories. Thus Lagos became the capital of Nigeria rather than Ibadan, Ife or Sokoto; Accra the capital of Gold Coast rather than Kumasi; and Bamako with its good links to the Senegalese coast rather than Timbuktu. Some colonial capitals, including Lusaka, Nairobi, Salisbury and Windhoek were created de novo outside preexisting polities in order to service the logistical and health needs of white conquerors. ..In extreme examples on how African capital cities did not follow the European pattern of extending power, Mauritania and Bechuanaland were actually ruled by capitals outside their nominal boundaries during the colonial period Saint-Louis and Mafeking, respectively" (16-17).

In line with this analysis, Campante, Do, and Guimaraes (2018) present cross-country regressions showing that capital isolation is associated with misgovernance (and a higher degree of civil conflict involving rebels aiming to overturn the government); the link between capital isolation and misgovernance is especially strong in autocratic and semi-democratic countries (including many African ones). ${ }^{40}$ Michalopoulos and Papaioannou (2014), using survey data, find that state's reach declines as one moves away from the capital. Hunziker, Muller-Crepon, and Cederman (2018) further show that rebellion is higher in ethnic homelands that are disconnected from African capitals.

\subsubsection{Discussion}

Compared to the voluminous research on the legacy of colonial institutions, infrastructure, and educational/health investments, there is little work examining the impact of colonial borders and the formation of colonial artifacts on economic, social, and political development. This applies both to works focusing on Africa and those centered elsewhere. Building on the literature in international studies and political science, future research could tackle many issues. First, case studies are needed to better understand how colony-protectorate borders shaped early and post-independence development. Second, African-wide research should move beyond Murdock's map to account for noise, inconsistencies, and errors. Applying cross-disciplinary approaches and perhaps using region-specific ethnic maps, research should try to provide an updated, refined, and less cluttered map portraying the spatial distribution of African groups before colonization (allowing for overlaps) and then reconstruct refined measures of ethnic partitioning. Third, combining historical narratives with contemporary microdata, future research can examine the impact of various aspects of the border and colony design on development by conducting counterfactual analyses. Fourth, theoretical works could model the trade-offs. Finally, since artificial border design during colonization was not limited to Africa, future research could assess the impact of colony-protectorate border making in other parts of the world, such as the Middle East, whose political and economic development path has been linked to colonial treaties.

\footnotetext{
${ }^{40}$ Campante and Do (2014) uncover a robust positive relationship between capital city isolation and corruption across US states and provide evidence that this reflects lower levels of accountability among politicians as well as weaker checks and balances.
} 


\section{The Slave Trades ${ }^{41}$}

\subsection{Overview, General Thesis}

Europeans' influence on Africa starts well before the colonial era. In the three-to-four centuries preceding Africa's colonization, the continent experienced one of its darkest periods: the slave trades. From the early 1500s through the late 19th century, approximately 12 million Africans were shipped (mostly) from West and Central Africa to South America (mostly to Salvador and Guyana), the Caribbean (mostly to Cuba, Jamaica, and Dominica), and the Southern United States. Europeans, who set up large plantations in the Americas, relied heavily on African labor. Besides the well-known transatlantic slave trade, Africa suffered from three less well-known, smaller slave trades: the Indian, Red Sea, and trans-Saharan trades. Slaves were shipped from East Africa to India and Indochina, mostly to work in plantations; from the Sahel and the Horn of Africa, slaves were shipped to North Africa, the Middle East, and to a lesser extent to India.

The magnitudes of the exact numbers vary. Nunn (2008) estimates that in total, close to 20 million Africans were taken as slaves. These estimates do not include those who died during the raids and the warfare; nor do they include those dying en route to Africa's slave ports. Manning (2013) argues that by 1850, when slavery was abolished, Africa's population was half of what it could have been in the absence of the slave trades, though Whatley and Gillezeau (2011) provide more conservative estimates of a $10 \%$ population decline. Figures 10a-10b illustrate Africa's slave trades, using Nunn's (2008) careful work. ${ }^{42}$ Figure 10a plots the (log) number of slaves per square kilometer at the contemporary country level using info from all four slave trades. Figure 10b gives the corresponding statistics for the Atlantic and the Indian slave trades at the ethnicity level, respectively, using Murdock's map on the spatial distribution of African ethnicities before colonization. [Data for the two smaller slave trades are not available at the ethnicity level] As the transatlantic slave trade was considerably larger than the other ones, ethnicities in West Africa and Central West Africa suffered the most. Africans close to Zanzibar, which served as the hub of the trans-Indian slave trade in Tanzania, Mozambique, and Madagascar, were also highly affected.

All evidence suggests that the slave trades represented a turning point in the continent's history. Warfare spread as African kings, chiefs, and headmen raided villages and towns, enslaving locals to sell them to European "merchants" in the ports. The slave trades laid the seeds of many major African wars (Besley and Reynal-Querol (2014)) and the weakening of African kingdoms. More than half of enslaved Africans were taken in a major war or kidnapped in targeted raids; a considerable portion were enslaved by friends and relatives (Nunn (2017)).

\footnotetext{
${ }^{41}$ Nunn (2017) also summarizes the slave trade literature. Bertocchi (2016) reviews works on the impact of slavery on both origin and destination countries and regions. From Slavery to Aid Politics and in the Nigerien Sahel 1800âĂŞ2000 (2015) gives an eloquent narrative of slavery in West Africa.

${ }^{42}$ Nunn (2008) used historical archives and records from all slave ports to construct the series. While there is noise in the statistics, most likely his estimates are on the conservative side. The Trans-Atlantic Slave Trade database (www.slavevoyages.org) at Emory University provides detailed information by port and voyage.
} 


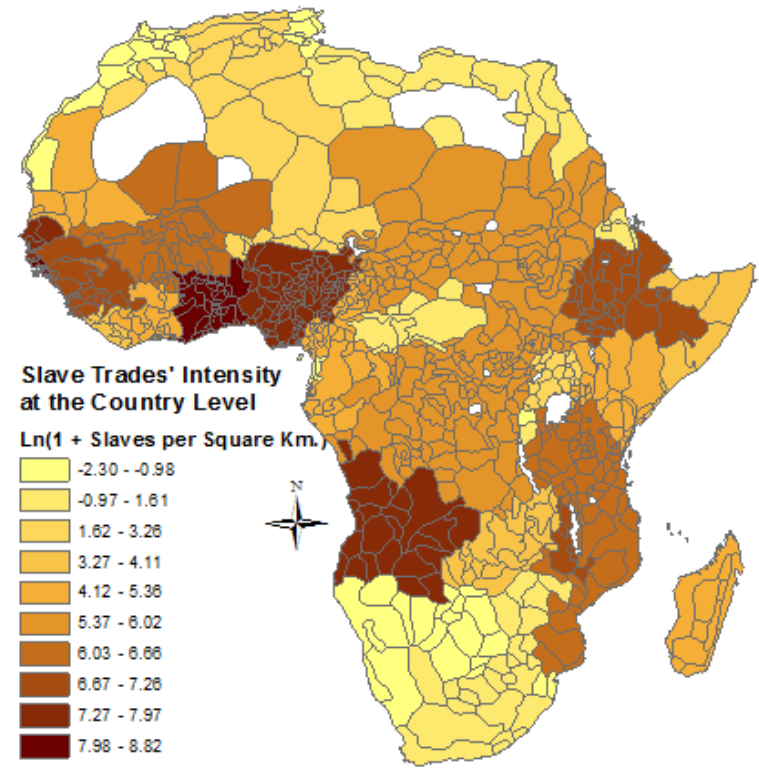

Figure 10a: Slave Trades at the Country-level

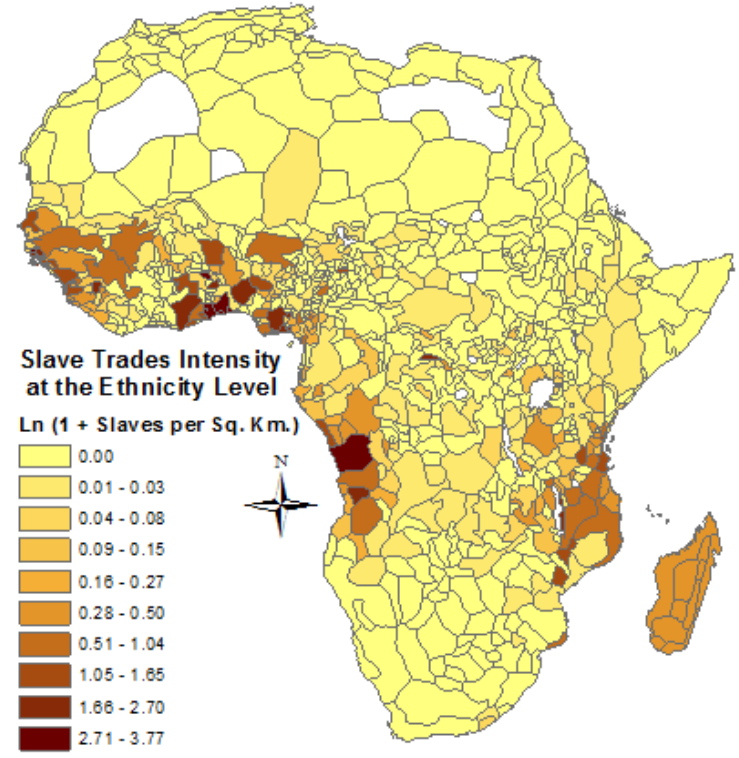

Figure 10b: Slave Trades at the Ethnicity-level

Many argue that Africa's slave trades have played a major role in Africa's (relative) economic and political underperformance since independence. ${ }^{43}$ In influential work, Nunn (2008) uncovered for the first time a strong link between Africa's slave trades and contemporary development. Figure 11 summarizes his results. Economic development, as reflected in the log of GDP per capita, is, on average, lower in countries whose population was affected the most by the slave trades. Nunn (2008) shows that the association remains robust to geographic and colonial controls. "Reverse causation" concerns are muted, as the slave trades did not affect initially underdeveloped places; if anything, strong and more economically advanced African states with higher population densities, like the Kongo kingdom, were affected the most. Perhaps a more important issue regards measurement error in the slave trades estimates (as well as in GDP). To account for error-in-variables and other endogeneity concerns, Nunn (2008) estimates instrumental variable specifications, exploiting demand-side variation across the Atlantic and Indian Oceans. He uses sailing distance from each African country to the closest slave selling location (e.g., Salvador in North Brazil). The IV specifications show that the component of countries' impact from the slave trades driven by its proximity to coastal slave markets is a strong correlate of contemporary development. The coefficient

\footnotetext{
${ }^{43}$ For example, in his masterpiece Things Fall Apart, Chinua Achebe describes eloquently the devastating role of the slave trades on beliefs, norms, and political institutions in Nigerian Igbo communities.
} 
magnitudes are also larger in absolute value, consistent with noise in the slave-trade estimates.

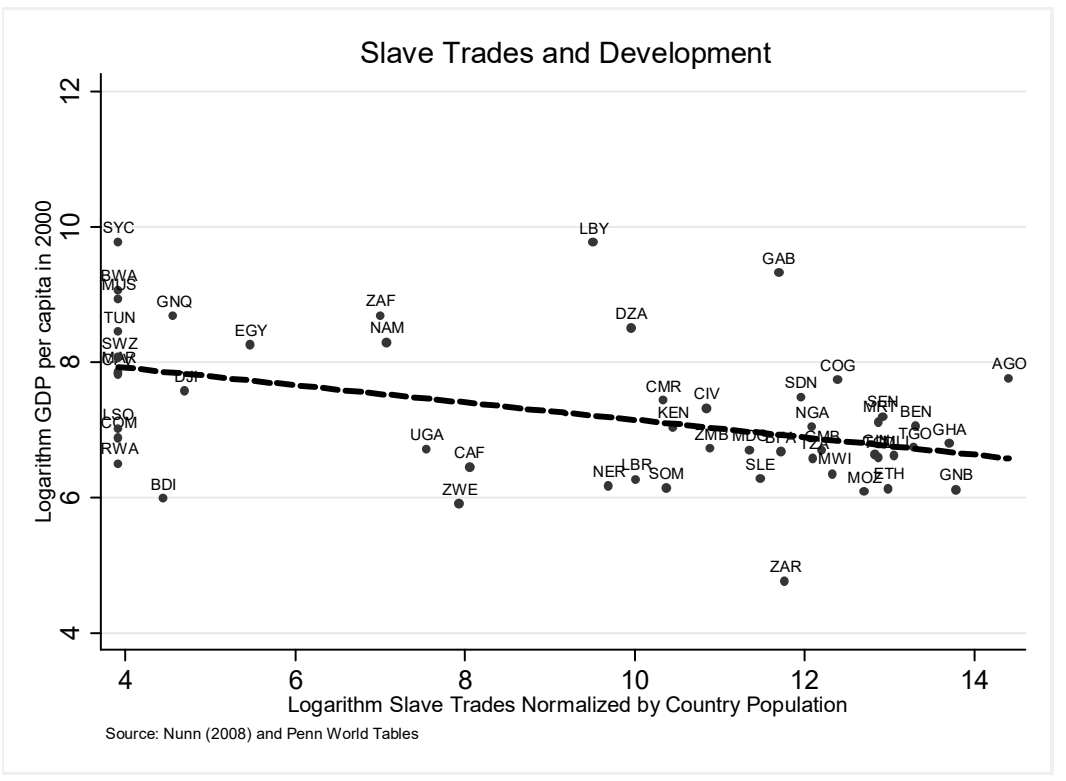

Figure 11: Slave Trade Intensity and Economic Development (Nunn (2008))

Nunn and Puga (2012) provide indirect evidence on the slave trades' legacy. While terrain ruggedness and distance to the coast are geographic traits that have been found to impede trade and are overall negatively related to GDP across the globe, their association with economic performance is the opposite within Africa. This is because more mountainous regions further away from the ports were less affected by the slave trades.

\subsection{Mechanisms}

Nunn's (2008) work spurred subsequent research that aimed to identify the main channels.

\subsubsection{Fractionalization}

Nunn (2008) provided some evidence that slave trades are associated with a higher degree of ethnic fractionalization, which, since the work of Easterly and Levine (1997), has been linked to Africa's tragedy. ${ }^{44}$ Adopting a "constructivist" view of ethnicity, Nunn (2008) argued that the violence and insecurity caused by the slave trades impeded the consolidation of small tribal clans into larger, more coherent ethnicities. Green (2013) extended this finding; working in a global sample, he presents cross-country evidence that slavery is a strong correlate of ethnic diversity. Whatley and Gillezeau (2011) provide further supportive evidence on the link between the slave trades and fractionalization. They first divide the western coast of Africa into 200 evenly spaced $50 \mathrm{~km}$ points from Tunisia to Cape Town. They then associate the number of

\footnotetext{
${ }^{44}$ We should stress, however, that the correlation between (log) GDP per capita and ethnic-linguistic fractionalization is not strong when looking within Africa. Recent research stresses aspects of ethnic-linguistic fragmentation, such as polarization, ethnic inequality, and cultural diversity, rather than fractionalization (Montalvo and Reynal-Querol (2005), Alesina, Michalopoulos, and Papaioannou (2016), Desmet, OrtuÃśo-OrtÃyn, and Wacziarg (2017)).
} 
ethnicities in buffers around each point to the number of slaves exported from nearby ports. The analysis uncovers a significantly positive link between the slave trades and the number of ethnic groups.

\subsubsection{Conflict}

Recent works link contemporary violence and civil conflict in Africa to historical conflict, which accelerated during the slave trades. In 1839 Thomas Clarkson summarized the role of the slave trades in fueling conflict: "It was not the war which was the cause of the Slave Trade, but the Slave Trade which was the cause of the war" (Clarkson (1839), taken from Whatley (2018)). Exploiting cross-country and within-country variation, Besley and Reynal-Querol (2014) uncover a strong legacy of historical conflict, to a great extent shaped by the slave trades, on contemporary conflict. Besley and Reynal-Querol (2014) combine historical georeferenced conflict data from Brecke (1999) during the period from 1400 to 1700 with contemporary civil conflict and violence data from ACLED (Figure 8a). First, they report cross-country regressions yielding a robust correlation between political violence and civil war with historical conflict and the slave trades in particular. Second, there is a significantly positive within-country correlation between historical and contemporary conflict. Third, using Afrobarometer data, they show that historical conflict is related to higher (lower) levels of ethnic (national) identification and mistrust. Zhang and Kibriya (2016) examine the slave trades' impact on contemporary conflict (as reflected on ACLED data) exploiting variation across ethnic homelands using Murdock's map and estimates of enslavement from Nunn and Wantchekon (2011). They find that slave trades correlate significantly with the intensity and duration of conflict.

Fenske and Kala (2017) provide further evidence on the slave trades - conflict nexus; they study historical conflict in western Africa in the three decades before and after the suppression of the slave trades in 1807 with the United Kingdom's Slave Trade Act and the prohibition of slave imports by the United States the next year. They first document a high degree of historical conflict close to slave ports. Second, they show that after 1807 - 1808, conflict related to the slave trades intensified in southern West Africa, as (mostly) Brazilian and Portuguese slave merchants were unaffected by these legislative changes. The rise of the price of slaves led to a reorganization of the market, with exports falling considerably from (Britishcontrolled) Nigeria, the Gold Coast, Sierra Leone, and French West Africa and increasing in Angola, Belgian Congo, and Namibia. Third, Fenske and Kala (2017) show that conflict among Africans also increased in northern West Africa. This "substitution" of conflict most likely happened as local elites, who benefited from the slave trades, tried to maintain power, fighting over other resources and the weakening of African kingdoms that derived revenues from the slave trades (this seems to be the case in Senegal, Gold Coast, and South Nigeria). This result is important, as it shows how past conflict persists, even when its original causes are absent. Boxell (2018) also documents that enslavement and conflict went in tandem during the first half of the 19th century. 


\subsubsection{Trust}

Nunn and Wantchekon (2011) examine the role of the slave trades on inter-ethnic trust that correlates with development both across and within countries (Algan and Cahuc (2014)). They develop an interesting hypothesis: the insecurity, violence, and warfare that characterized the slave trades period lowered trust. The slave trades led to inter-ethnic animosity and distrust, as quite often members of some ethnic group would raid other groups' towns to capture slaves; they may have also weakened general and intra-ethnic trust, as quite often friends and relatives would trick, kidnap, and sell each other. Nunn and Wantchekon (2011) test this hypothesis, combining ethnic-level information on the impact of transatlantic and Indian slave trades with contemporary data on trust from the 2005 Afrobarometer Surveys that covers roughly 22, 000 respondents in 17 sub-Saharan African countries. The analysis reveals a strong legacy of the slave trades on mistrust. Groups that suffered more from slavery exhibit lower trust toward family and others from the same or other ethnic groups. This finding suggests that distrust has persisted across generations, perhaps also fueled by colonial extractive practices. The average ethnicity-based slave export index of other respondents in the same town, district, and province is also negatively related to trust, suggesting sizable spillovers.

\subsubsection{Population Dynamics and Family Structure}

As the colonies in the Americas needed manual labor, slave traders targeted physically strong men. As such the slave trades, and especially the transatlantic one, altered the male-female ratio (Manning (2013), Fage (1980), Thornton (1983), Lovejoy (2004)). For the most-affected communities, there are estimates of three women per one man. The relative absence of men seems to have spurred polygyny, which is still widespread in Africa (Fenske (2015)). Edlund and Ku (2011) present cross-country regressions showing a robust correlation between polygyny and the transatlantic slave trades. Polygyny is in turn related to higher infant and child mortality rates. Dalton and Leung (2014) present evidence that the higher prevalence of polygyny in West Africa reflects the slave trades' impact; there is a strong link between the transatlantic trade's and the ethnic-level practice of polygyny. The correlation breaks down in Eastern Africa, which was mostly impacted by the Indian Ocean slave trade that affected both men and women. Using DHS data, Bertocchi and Dimico (2015) also document a positive association between an ethnicitybased index of slave trade intensity and polygyny. They also uncover a link between slave trades and female infidelity, which they attribute to forcing women into polygamous marriages from a young age. They then show that the slave trades are related to a higher HIV infection rate among married women.

Teso (2017) examines the impact of the sex imbalance, driven by the slave trade, on contemporary female labor force participation, using DHS data covering more than half a million women in 21 subSaharan countries. He finds that women from ethnicities exposed to the transatlantic slave trade are much more likely to be in the labor force and be employed in more prestigious occupations. This effect is present for older and younger cohorts. And while the coefficient drops, the association retains significance 
even in within town/village specifications. He further shows that women whose ancestors were affected the most from the transatlantic slave trade have lower fertility rates and are more likely to participate in household decisions. To assuage endogeneity concerns, Teso (2017) shows that there is no association between the slave trades and men's participation in the labor force nor a correlation between female labor force participation and exposure to the Indian Ocean slave trade that affected men and women equally.

\subsubsection{Political Institutions and Corruption}

In his overview, "Slavery and the African Life," Patrick Manning writes that "slavery was corruption that involved theft, bribery, and exercise of brute force as well as rouses. Slavery thus may be seen as one source of precolonial origins of modern corruption." Building on insights by Law (1991), Inikori and Engerman (1992), and Rodney (1972), among others, Robinson (2002) hypothesized that "slavery-induced predatory institutions" established during the 16th to18th centuries may have laid the seeds for extractive colonial institutions and in turn for post-independence authoritarianism, weak property rights, and poor contract enforcement.

Whatley (2012) examines the impact of the slave trades on precolonial political authority, combining data from the Trans-Atlantic Slave Trade database and information from Murdock (1967) on ethnicities' ways of appointing local headmen. Focusing on West Africa, he uncovers a significant correlation between exposure to the transatlantic slave trade and absolutist ethnic institutions. This correlation retains significance once he controls for local geographic characteristics and when -following Nunn (2008)- he instruments slave trades impact using distance to ports. Whatley (2012) then reports the colony-wide specifications of a significant link between the slave trades' impact and indirect rule. He argues that the culture of recruiting locals to capture and kidnap slaves in the precolonial period persisted during colonization, as European colonizers found it easier in the slave-trade affected communities to rule via local chefs and elites.

Obikili (2016) shows that exposure to the slave trades is related to a low degree of political centralization. Ethnicities severely affected by the transatlantic slave trades are more likely to be "fragmented", lacking centralized political authorities and state-like institutions. This is important, as ethnic-specific political centralization is strongly related to contemporary development (see the discussion in the next section). Obikili (2016) presents survey-based evidence from Nigeria and Tanzania, places that were severely and symmetrically affected by the transatlantic and Indian Ocean slave trades, that individuals from areas affected by the slave trades are more likely to report bribery payments.

\subsubsection{Finance and Entrepreneurship}

Recent works connect the slave trades to Africa's low levels of financial development, which in turn connects to economic efficiency via numerous mechanisms (see Levine (2005) for a review). Pierce and Snyder (2017) use data on access to finance from the World Bank's Enterprise Survey, which covers over 15, 000 firms 
in 38 African countries. Exploiting within-country regional variation, they show that in places exposed to slave trades, firms report that accessing credit is a serious obstacle to firm growth. They then uncover a strong negative cross-country correlation between slave trades and bank loans, private credit, and the availability of overdraft facilities, and checking accounts. Slave-trade exposure is unrelated to trade credit (from customers and suppliers), which often acts as a substitute for formal credit. Pierce and Snyder (2017) further show that the slave trades' effects on firms' access to credit are especially strong for small firms that are not part of business groups.

Levine, Lin, and Xie (2017) go a step further, examining how the slave trades shaped contemporary financial patterns. In the first part of their analysis, they confirm the results of Pierce and Snyder (2017): conditional to the overall level of economic development, there is a negative association between exposure to the slave trades, and various proxies of financial markets' depth, and firms' and households' access to finance. Using the approach of Rajan and Zingales (1998), they show that the negative correlation between slave exports and access to finance is especially strong for sectors that depend on external finance. Second, they examine the mechanisms of three channels: information sharing, trust in financial institutions, and legal protection of investors and contract enforcement. Slave exports are negatively related to private information-sharing institutions (such as credit registries). Slave trade exposure also relates to distrust toward financial institutions, a result that adds to the link between slavery and general trust discovered by Nunn and Wantchekon (2011). Levine, Lin, and Xie (2017) do not detect an association among slave exports and investor protection, court efficiency, and property rights.

\subsubsection{Education}

Obikili (2016) notes that there is a significantly negative cross-country correlation between slave exports and literacy. Given the strong link between education and GDP, this cross-country correlation comes at no surprise, yet it hints that perhaps the slave trades have played a role in shaping human capital. Using census data from the late colonial era in Nigeria and the Gold Coast, Obikili (2016) shows that literacy rates are lower in ethnic homelands and districts affected the most by the slave trades.

Okoye and Pongou (2015) also examine the impact of the slave trades on education, recognizing, however, that slave trades may have indirectly fostered human capital accumulation, as Christian missions moved to the slave coast, aiming to heal slavery's impact. Using DHS data from Nigeria in 2008, Okoye and Pongou (2015) examine jointly the role of the slave trades and Christian missions on contemporary literacy. Besides uncovering a significantly positive correlation between schooling and proximity to the main (early) Christian missions, they find a significant negative association with slave exports. Although Christian missions took place mostly in the South and close to slave ports, the "direct" negative role of slave exports dominates the "indirect" positive impact via Christian missions. 


\subsection{On the Origins of the Slave Trades}

Given the plethora of evidence connecting Africa's slave trades to various contemporary development proxies, a natural follow-up project is to understand the factors that shaped them. Nunn (2008) emphasized the role of demand, mostly from the Americas, where African slaves were mostly used in plantations. Nunn and Puga (2012) look at the supply side, stressing the role of geography. Inland African regions with rugged terrain were shielded from the slave raids, a feature that explains their relatively better performance. Whatley (2018) presents evidence of a strong link between the penetration of guns and enslavement, a finding that supports the idea that technological improvements on gunpowder technology contributed to the continuation of the slave trades. ${ }^{45}$

Fenske and Kala (2015) show that abnormal weather events contributed to the acceleration of enslavement. Combining slave shipment data with historical temperatures at a 5-degree grid-cell level, they uncover a significant increase in slave exports in abnormally cold years. As the cost of raiding for slaves and fighting is higher in warm periods, the authors interpret these findings as indicative of supply-side considerations (costs) on enslavement. They complement the regression analysis with eloquent descriptions of the role of temperature shocks on enslavement in Mozambique, Benguela (in Angola), and Whydah (in Benin), regions that served as hubs during the slave trade period.

Boxell (2018) provides the most comprehensive exploration of the long-standing conjecture of historians that climate conditions, draughts in particular, played a crucial role on enslavement. Africa seems to have suffered a prolonged dry period from roughly 1630 till 1860, which seems to have fueled conflict and population movements. Boxell (2018) uses rainfall data from 1801-1866 to test these conjectures. First, Boxell (2018) shows that negative rainfall shocks substantially increased the number of slaves exported from the region experiencing the shock. A one standard deviation fall in the previous year's precipitations leads to an increase of annual slave exports by roughly 475 slaves. Second, medium-run falls in rainfall also raise the number of exported slaves. Third, draughts tend to increase local mostly interethnic conflict. Forth, using info on illegally exported slaves, after the British Slave Trade Act of 1807, he shows that draughts tend to increase enslavement of children, a result that is in line with anecdotal evidence of families selling children or using them as "debt collateral". Forth, there is not much support to the idea that Africa demand for slaves played a role. Fifth, there is not much of a link between the disease environment and enslavement.

\subsection{Discussion}

The empirical literature on the impact of the slave trades on contemporary economic, social, and political development has progressed considerably, providing compelling evidence on its legacy. We believe that there is, however, space for future research.

\footnotetext{
${ }^{45}$ For example, the Asante Kingdom used imported guns to enslave locals. After the discovery of the gold mines, the Asante began trading guns with slaves.
} 
First, addressing measurement is important. For example, data on the Arab and the trans-Saharan slave trades are incomplete (and thus not covered in the data depicted in Figure 10b). In spite of the impressive effort of Nunn (2008) and the Trans-Atlantic Slave Trade database (Eltis, Behrendt, Richardson, and Klein (1999)), there are issues with the Western Africa data. Second, case studies, especially if accompanied by original data collection, are useful for shedding light on the micro aspects of the slave trades. Third, future work should combine information from the slave trades with the subsequent colonial period and provide thorough historical data-based narratives. This is crucial, as colonization and the slave trades are not independent events (Amin (1972)); Christian missionaries settled on the slave coast to offset their legacy (Okoye and Pongou (2015)). Colonial institutions (direct and indirect rule) are related to the preceding slave trade period (see From Slavery to Aid Politics and in the Nigerien Sahel 1800âĂŞ2000 (2015)). It would be interesting to examine how local elites and kingdoms developed during and after the slave trade period and to explore persistence. Fourth, future work could try to disentangle between the different forms of slavery (house slavery, enslavement for working in mines and plantations, enslavement for sending people to India, Arabia, and the Americas and slavery by local elites).

\section{Precolonial Political Centralization and Institutions}

This section takes up the literature examining the lasting legacy of precolonial formal and informal ethnic traits, with a focus on political centralization (statehood). We first present the general thesis. Then, we describe the ethnic landscape of political centralization on the eve of the colonial era. Third, we review works that link variation in precolonial statehood to contemporary development. Fourth, we discuss evidence on the mechanisms. Fifth, we review studies on the origins of ethnic institutions. Sixth, we provide a synopsis of works focusing on other-than-political centralization ethnic traits. Seventh, we offer some thoughts on future research.

\subsection{Thesis}

\subsubsection{General Overview}

A prominent line of thought in anthropology sees rough continua of social complexity, political centralization, and technological sophistication, running from "band-level" societies to "state-level" groups, ultimately supporting the emergence of urban centers and more complex divisions of labor (Johnson and Earle (2000), Sahlins and Service (1960)). Starting with Karl Marx, Adam Smith, and others, political economists have stressed the interplay between societal political organization and the complexity of economic activity. While these inquiries were at the core of classical economics, they were sidelined during the 20th century. Reversing this trend, over the last two decades economists have brought their theoretical and empirical toolsets to bear on the coevolution of statehood and economic performance. Besley and Persson (2011) provide a thorough treatment of recent research, connecting fiscal and state capacity to 
development, conflict, and industrialization (see also Bardhan (2016)). The literature stresses many beneficial aspects of political complexity, related, among others, to the provision of security, infrastructure investments, promotion of trade, and the development of tax and bureaucratic systems. While there is a lively debate on whether the progress toward social and technological complexity is an outcome of geography (Diamond (1997)), culture (Landes (1998)), or institutions (Acemoglu and Robinson (2012)), there is widespread agreement that politically centralized societies have been better equipped to provide some form of property rights and safety necessary for economic activity (Tilly (1985), Migdal (1988), Hintze (1970)).

Africa's underdevelopment has been linked to its lower levels of political centralization relative to the rest of the Old World. At the time of colonization, Africa had few politically centralized ethnicities; compared to Europe and Asia, there were fewer kingdoms, empires, and state-like entities. Candidates explaining this phenomenon range from ecological factors inhibiting the rise of high population densities to the relative dearth of inter-state conflict delaying the strengthening of empires and kingdoms (e.g., Herbst (2000), and Besley and Reynal-Querol (2014)). Heldring and Robinson (2012) argue that in many instances colonization upended the indigenous development of complex centralized political structures, as in Rwanda, Ghana, and Botswana.

Bockstette, Chanda, and Putterman (2002) construct a measure of statehood experience from AD 1 through AD 2000 and find that it accounts for a considerable fraction of cross-country variation in development. Putterman and Weil (2010) adjust this index for the historical experience with statehood of people residing in a given country today; they then show an even stronger positive correlation between the heritage of statehood and economic development. These cross-country associations are in line with conjectures attributing part of Africa's relative underdevelopment before colonization to the sparsity of politically centralized states. Yet, even if one wanted to set aside issues of reverse causation (that is, development leading to more complex political structures), intercontinental differences in geography-ecology, culture, and history obscure the interpretation of these patterns.

\subsubsection{African Context}

Africa-related research exploits the differences in political centralization during precolonial times to quantify their influence on various facets of contemporary local development. The legacy of ethnic-based political institutions becomes more salient when seen in light of the fact that contemporary politics are often characterized by ethnic patronage and favoritism (e.g., Posner (2005), DeLuca, Hodler, Raschky, and Valsecchi (2015), Burgess, Jedwab, Miguel, Morjaria, and Padro-i-Miguel (2015), Franck and Rainer (2012), and Dickens (2018)). There is widespread evidence of ethnic discrimination and several of Africa's civil wars have an explicit ethnic dimension (Wimmer, Cederman, and Min (2009)). At the same time, many Africans self-identify with ethnicity, and ethnic leaders are perceived to be less corrupt and more trustworthy than elected politicians (Logan (2011), Michalopoulos and Papaioannou (2015b)). In many settings, land allocation is governed by ethnic -rather than national- institutions, and the constitutions of some African 
countries (e.g., Ghana and Uganda) explicitly recognize the role of ethnic chiefs (e.g., Englebert (2002)). Chiefs often adjudicate disputes following customary laws and traditions (e.g., Goldstein and Udry (2008)). In some places chiefs collect taxes and have some role in the allocation of mining rights (Glennerster, Miguel, and Rothenberg (2013)). Baldwin (2016) reviews case studies illustrating the prominent role of traditional authorities.

Ethnic institutions have endured the colonial and post-independence era for many reasons. First, in many cases, Europeans did not alter pre-existing political (and social) structures, as colonization was (with exceptions) quite limited regarding both its timing and its territorial reach. European settlements in Africa were confined to the capitals, and power was mostly broadcast by a small number of administrators. Second, via the indirect rule doctrine Europeans strengthened the role of tribal chiefs and kings via the indirect-rule doctrine (see Section 2). Davidson (1992) discusses cases where colonizers reinforced ethnic identities by tailoring indirect rule along ethnic lines. Third, African governments upon independence found it difficult to govern in rural, remote areas. As a result, Africans, especially those residing in the periphery, continued to rely on ethnic-specific structures rather than the national government (Englebert (2009)). Herbst (2000) notes that in Mauritania, Mozambique, Niger, Nigeria, and Chad, while the first post-independence national governments tried to marginalize traditional leaders, the national authorities soon realized the extraordinary difficulties in administering rural areas and formed alliances with local tribal chiefs (see also Spear (2003)). Fourth, De Juan (2017) argues that idiosyncrasies in local topography have played a crucial role in both the emergence and persistence of ethnic institutions. He provides supportive evidence from Burundi, where a deeply-rooted conflict-resolution institution (bashingantahe) has persisted in spite of various colonial and post-independence policies that weakened it and eventually abolished it in 2010.

\subsection{Mapping Precolonial Political Centralization}

The ethnographic coding of political complexity for hundreds of African groups upon colonization has greatly aided research on the role of precolonial institutions. Figure 12 portrays Murdock's (1967) "Jurisdictional Hierarchy beyond the Local Community Level" codification across ethnicities, using the spatial distribution of groups from his earlier work (Murdock (1959)). This index describes the number of jurisdictional layers above the local (village) level. A zero indicates societies "lacking any form of centralized political organization." A score of 1 indicates small chiefdoms; 2 designates paramount (large) chiefdoms; 3 and 4 indicate ethnic groups that were part of large states. ${ }^{46}$

\footnotetext{
${ }^{46}$ Murdock's classification is in line with Fortes and Evans-Pritchard (1940) early analysis of African societies. Fortes and Evans-Pritchard (1940) categorized ethnic groups into two coarse political systems: "One group consists of those societies which have centralized authority, administrative machinery, and judicial institutions - in short, a government-and in which cleavages of wealth, privilege, and status correspond to the distribution of power and authority. This group comprises the Zulu, the Ngwato, the Bemba, the Banyankole, and the Kede. The other group consists of those societies which lack centralized authority, administrative machinery, and judicial institutions-in short, which lack government-and in which there are no sharp divisions of rank, status, or wealth. This group comprises the Logoli, the Tallensi, and the Nuer." Diamond (1997) allows for an intermediate category for groups organized as chiefdoms or loose alliances where some state features were present.
} 
Before discussing works using these data, we need to be transparent on their limitations. Murdock's map and institutional classification are noisy measures of the true processes. First, ethnicities overlapped, at least to some extent. Ethnic boundaries became blurred far from the main towns, as the reach of precolonial African kingdoms fizzled in remote areas (Herbst (2000)). Second, there are delicate differences within ethnic clusters in political organization and other societal traits that are not discussed by Murdock (1959, 1967). Third, the dataset records ethnic political (as well as economic and social) traits at a specific point in time, the late 19th and early 20th centuries, but does not shed light on the historical depth of these features. Fourth, as historical accounts of precolonial Africa are scant, coverage differs across the continent, perhaps in a non-random manner. Fifth, there is "pure" measurement error as the ethnic boundaries are coarse and because there is sizable heterogeneity on underlying resources. ${ }^{47}$

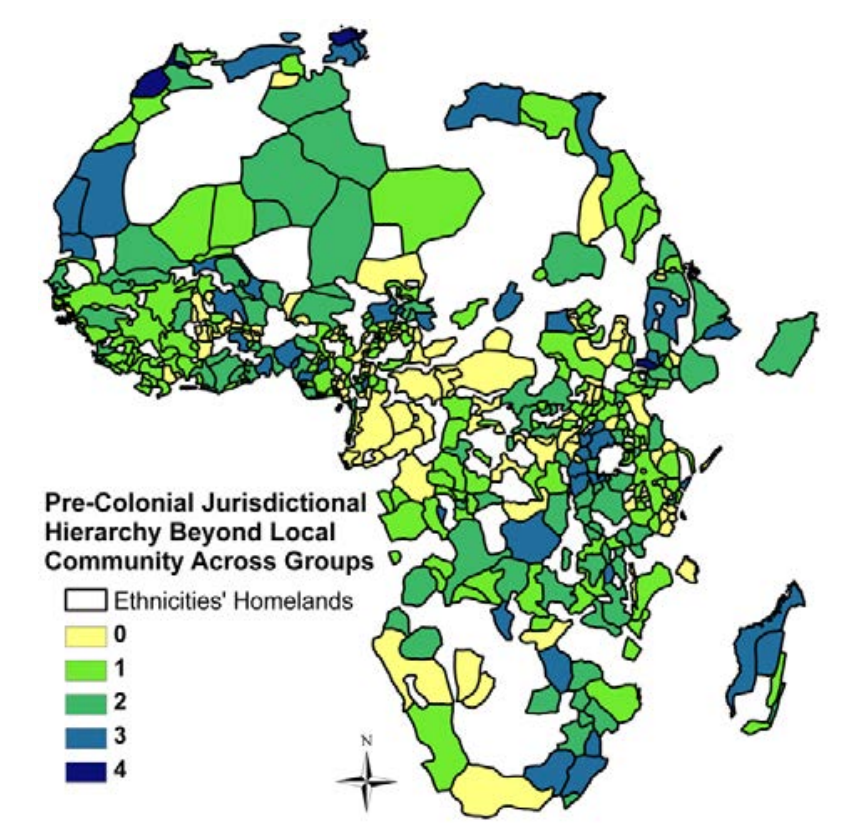

Figure 12: Political Centralization (Murdock, 1959, 1967)

\subsection{Cross-Country Patterns}

In an early contribution, Gennaioli and Rainer (2007) established a country-level association between precolonial political centralization and economic performance. The authors used Murdock's jurisdictional hierarchy to calculate the percentage of the population that belongs to politically centralized groups, defined as being neither stateless nor organized as petty chiefdoms. Gennaioli and Rainer (2007) find that countries lacking strong precolonial political centralization, such as Liberia and Sierra Leone, have lower immunization rates, lower educational attainment, and higher infant mortality rates than countries with politically centralized ethnic groups, such as Lesotho, Swaziland, Botswana, and Rwanda. Gennaioli and Rainer (2006) further show that national institutional quality is higher in countries that score high on the

\footnotetext{
${ }^{47}$ As we discuss below, revisiting Murdock's map and classification of ethnic traits should be a priority of future research.
} 
ethnic-specific precolonial political centralization proxy.

Case Studies Comparing Sierra Leone to Botswana is illustrative of the cross-country patterns. On the one hand, Botswana's success in securing property rights and providing a stable environment for foreign investment has been credited to the inclusiveness of its precolonial institutions originating in the accountability of Tswana chiefs, as exemplified by the debates in local and inter-clan assemblies, the $\mathrm{kgotlas}$ (Schapera (1970)). The Tswana king, while powerful, was subject to checks by senior chiefs, who in turn cooperated with local administrators and various advisory bodies. Acemoglu, Johnson, and Robinson (2003) attribute Botswana's relative post-independence economic prosperity to the perceived legitimacy of the Botswana Development Party and its administration, seen as a continuation of Tswana institutions (see also Hjort (2010) and Hilbom (2014)). On the other hand, Acemoglu, Chaves, Osafo-Kwaako, and Robinson (2016) attribute Sierra Leone's mediocre post-independence performance to the inability of the state to broadcast power and monopolize violence, features that stem from the lack of strong precolonial states. The Mende and the Temne, Sierra Leone's main ethnic groups, as well as smaller ethnicities lacked state-like institutional mechanisms. The absence of formal authority allowed the British colonial administration to install paramount chiefs. The latter, upon decolonization, became the main conduit for patronage politics.

\subsection{Within-Country Patterns}

In Michalopoulos and Papaioannou (2013), we examine the role of pre-colonial political centralization at the ethnic homeland level. This is possible because within the boundaries of contemporary states, ethnicities with different political legacies reside. This approach, while not perfect, has some benefits. First, the inclusion of country fixed effects accounts for colonial features related to the identity of the colonizer, the type of colonial rule, and post-independence nationwide features, such as macroeconomic (and other) policies and national institutions. Second, by performing the analysis at the regional level, we account for observable local geographic, ecological, and other time-invariant traits. Third, the considerable cross-ethnic variability allows us to examine heterogeneity.

A key challenge to conducting the regional analysis is the paucity of economic indicators at a fine resolution. To circumvent this, we used satellite imagery on light density at night to proxy for local development. ${ }^{48}$ Figure 13 summarizes the results. The bar plot gives the likelihood that pixels (of 12.5 $x 12.5$ decimal degrees) are lit for small and paramount chiefdoms and states (with acephalous societies serving as the omitted category). The bar plot presents several specifications: (i) without controls; (ii)

\footnotetext{
${ }^{48}$ This approach follows Henderson, Storeygard, and Weil (2012) and follow-up works, which have uncovered a strong link between GDP (per capita) and luminosity across and within countries (e.g., Pinkovskiy and Sala-i-Martin (2016), and Pinkovskiy (2017)). Luminosity has been used as a proxy of local development in numerous recent studies (e.g., Hodler and Raschky (2014), Michalopoulos and Papaioannou (2014), Alesina, Michalopoulos, and Papaioannou (2016), and Henderson, Squires, Storeygard, and Weil (2018)). Donaldson and Storeygard (2016) and Michalopoulos and Papaioannou (2018) review studies using satellite data and luminosity, in particular, in economics.
} 
simply adding country fixed effects or (iii) conditioning on contemporary log population density, or (iv) both, and (v) including a rich set of location-specific controls on top of country constants. Compared to societies lacking political hierarchy beyond the local level, economic development, as reflected in luminosity, is higher in small and especially large chiefdoms. Regional development is the highest in the ancestral homelands of societies that were organized as states at the time of colonization. The difference in luminosity is especially stark when comparing states and large paramount chiefdoms to stateless groups or petty chiefdoms. ${ }^{49}$

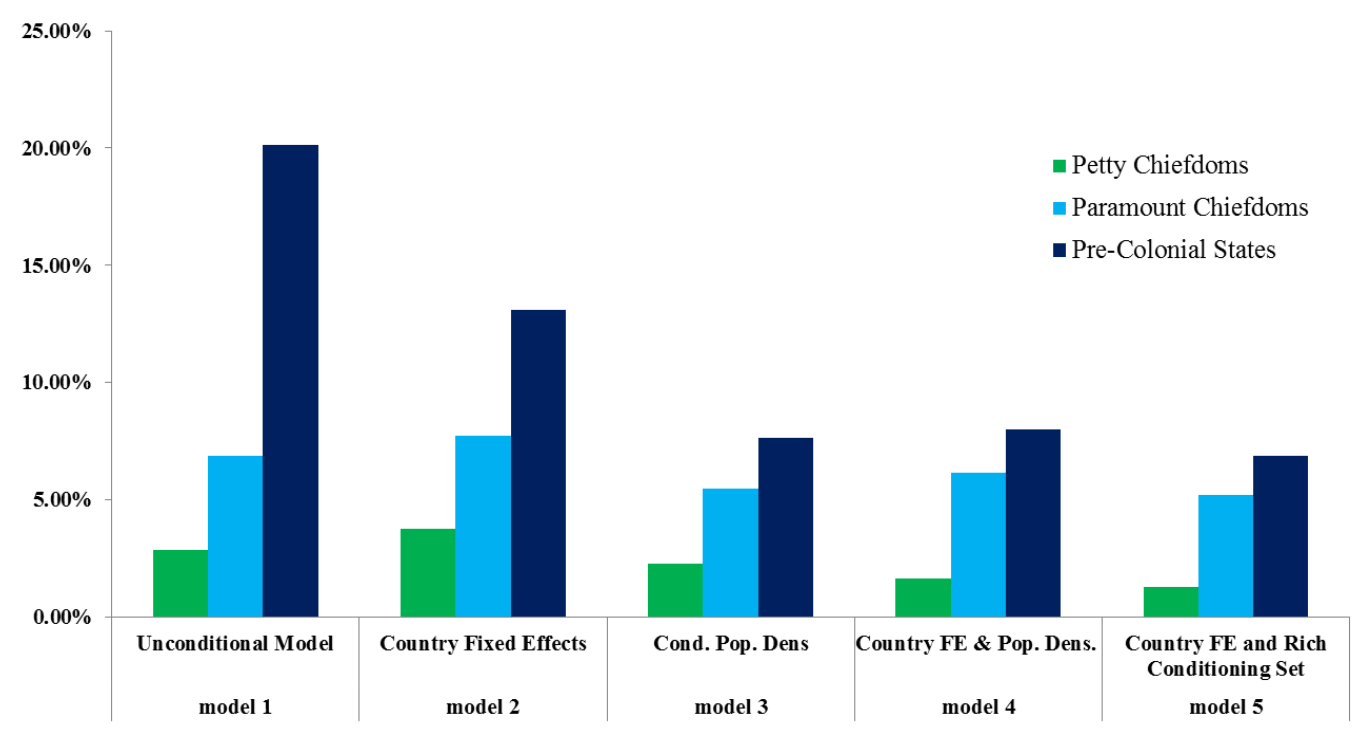

Figure 13: Political Organization and Development (Luminosity). Michalopoulos and Papaioannou (2013)

Although the dependent and main explanatory variables are measured more than 100 years apart, the estimates cannot be causally interpreted. First, it may well be the case that political centralization correlates with precolonial development and population density, and thus the estimates reflect inertia. Second, one could always come up with an omitted geographic-ecological factor that drives both development and pre-colonial institutions. Third, given noise in Murdock's map and classification issues, error-in-variables is a concern.

To partly account for these issues, in Michalopoulos and Papaioannou (2013 and 2015) we perform three tests. First, using the breadth of societal characteristics in Murdock (1967), we regressed luminosity on jurisdictional hierarchy and more than twenty other precolonial traits, capturing the type of economic activity (dependence on agriculture, hunting, fishing, animal husbandry, and milking of domesticated animals), societal arrangements (polygyny, presence of clans at the village level, slavery), early development (size and complexity of precolonial settlements), and proxies of local institutional arrangements (an indicator for the presence of inheritance rule for property, elections of the local headman, class stratification, and

\footnotetext{
${ }^{49}$ Chiovelli (2014) and Angeles and Elizalde (2017) and Dell, Lane, and Querubin (2018) provide similar evidence connecting contemporary development to historical political centralization in the Americas and in Vietnam, respectively.
} 
jurisdictional hierarchy at the village level). In all specifications, jurisdictional hierarchy beyond the local community enters with a positive, stable, and significant coefficient, suggesting that it is political centralization rather than some other observable societal feature that is a robust correlate of spatial, long-term development.

Second, to mitigate concerns that the link was driven by unobserved, hard-to-track factor(s), we compared (using a spatial regression discontinuity design) economic performance within pairs of adjacent ethnicities differing in political complexity. Across 252 pairs of contiguous homelands comprising a centralized and a non-centralized ethnicity, the probability that a pixel is lit is approximately $3 \%$ higher in the homeland of an ethnic group that was organized as a large chiefdom or state during the precolonial era. Third, to account for population mixing and the significant role of national institutions in the capitals, we dropped ethnic areas and pixels close to the capitals, finding that if anything the coefficients are larger and more precisely estimated. Furthermore, the link between precolonial political centralization is present when we use mapping of precolonial empires and kingdoms other than Murdock's (Besley and Reynal-Querol (2014)), see Michalopoulos and Papaioannou (2015a).

Case Studies These results are in line with Douglas (1962) comparison of the Lele and the Bushong, two adjacent groups separated by the Kasai River in the Democratic Republic of Congo with quite different precolonial histories. Douglas (1962) argued that the significant differences in well-being between the two groups are driven by the different institutions that govern their exchange, production, and work ethos, stressing the role of the king and that of hereditary chiefs in providing security that sustained trade and commerce (see also Vansina (1978) and Lowes, Nunn, Robinson, and Weigel (2017)).

Bandyopadhyay and Green (2016) assess the role of precolonial political centralization in Uganda using fine ethnographic data and conducting the analysis at the district and individual levels. Uganda is an interesting case, as its population consists of politically centralized ethnicities, the $\mathrm{Bu}(\mathrm{Ganda})$, Ankole, and $(\mathrm{Ba})$ Nyoro, as well as societies lacking any organization above the village level, like the Acholi and the Karamojong. Bandyopadhyay and Green (2016) uncover a positive correlation between ethnic centralization and well-being (literacy, Human Development Index, poverty).

\subsection{Mechanisms}

The cross-country and cross-ethnic-homeland results of Gennaioli and Rainer (2007) and Michalopoulos and Papaioannou (2013) do not identify the mechanisms at work. Recent studies, motivated by insights from African historiography, have stepped in to fill the vacuum.

First, Boone (2003) and Herbst (2000) argue that in centralized societies there is a relatively higher degree of accountability of local chiefs. In large chiefdoms and organized states there were bureaucratic layers, subjecting local leaders to monitoring by superior chiefs and hereditary kings. Moreover, centralized ethnic groups often had local assemblies where policies were discussed. In many instances, these structures 
endured the colonial era and post-independence nation-building process. Baldwin (2013), for example, finds that in Zambia chiefs facilitate investment in public services, particularly the construction of new projects. Jedwab and Storeygard (2017) provide cross-country regression evidence of a strong conditional correlation between precolonial political centralization and post-independence investments in transportation infrastructure, a result in line with Heldring (2016), who also documents a positive association between regions' experience with precolonial kingdoms and pre-genocide public goods in Rwanda (schools, roads). Yet, Bandyopadhyay and Green (2016) findings suggest a more nuanced picture, as in Uganda there is no link between precolonial political centralization and public goods.

A second mechanism relates to the presence of legal structures. Centralized groups allowed their subjects access to legal resolution mechanisms and property rights steadily emerged (Herbst (2000)). Douglas (1962) and Lowes, Nunn, Robinson, and Weigel (2017) emphasize the importance of Kuba Kingdom's legal institutions, courts, and an unwritten constitution in facilitating economic activity. Schapera (1970) documents that the Tswana had elaborate legal rules, courts, and processes, and even chiefs were subject to the law. Similarly, Hjort (2010) notes that Botswana courts have ruled for the (minority) Bushmen San people against the government's decision to evict them from their (diamond-rich) historical homeland. Baldwin (2013) shows that across Zambian regions there is a strong association between political centralization and the power of traditional leaders in administrating land. De Juan (2017) shows that informal conflict-resolution mechanisms in Burundi correlate strongly with the penetration of the precolonial Burundi Kingdom. Along similar lines, Broich, Szirmai, and Thomsson (2015) find that bureaucratic quality across African countries is positively linked to their precolonial legacy, especially after the democratic transitions in the 1990s. Fenske (2013) shows that precolonial political centralization is positively related to land rights.

Third, Schapera (1967) argues that centralized groups benefited during the colonial era by extracting more concessions from the colonial state. Some examples are supportive of the thesis, but there are also counterexamples (e.g. in Nigeria where the colonial administration and Christian missions underinvested in the Northern regions that were home to politically centralized Muslim ethnic groups). Acemoglu and Robinson (2012) describe how the Tswana leaders, thanks to the legitimacy of their institutional reach, convinced the British government to grant them a greater degree of autonomy. In Eastern Africa, British authorities collaborated with the Buganda king to split the kingdom's land -that was under communal customary law- between colonizers and local chiefs (Englebert (2000)). In some cases, Europeans settled and invested in the homelands of the more politically advanced groups, magnifying preexisting differences (e.g., Huillery (2009, 2011)).

Fourth, contemporary fiscal capacity may be linked to precolonial statehood. Bolt and Gardner (2015) compile a dataset providing a snapshot of native authorities in a handful of African countries during the late colonial period. The authors provide a thorough description of the complex creation process of native authorities, concluding that by the late colonial period what had been created through indirect 
rule in its various forms was a mixture of native administrations of different capacities of self-governance. They then argue that native authorities' tax ability is linked to their precolonial state history. This finding points to the persistence of state capacity from the precolonial to the colonial period, particularly in areas in Africa where indirect rule was practiced.

A fifth potential mechanism regards the presence of a strong state among the former that limits the extent of violence. Wig (2016) finds that centralized groups, when excluded from the national government, are less likely to be involved in civil wars. Centralized traditional authorities may more credibly bargain with the state, reducing the risk of conflict. Depetris-Chauvin (2014) uncovers a similar mitigating aspect of historical political centralization on the likelihood of contemporary civil conflict. Instead of relying on Murdock's classification, Depetris-Chauvin combines a wide variety of historical sources to construct an original measure of long-term exposure to statehood at the subnational level. He then shows that subnational territories with a longer historical exposure to statehood are less prone to experience conflict when hit by a negative economic shock. Using survey data, he further shows that within-country statehood experience is linked to people's positive attitudes toward local state institutions and traditional leaders. Larcom (2013) shows that contemporary African states that were stateless prior to colonization have lower levels of state enforcement and higher crime. Nevertheless, Heldring (2016) finds that during the 1994 genocide, regions within Rwanda that were under precolonial state rule experienced significantly more atrocities (although just before the genocide these regions were relatively more peaceful).

Sixth, precolonial political centralization is related to social norms. ${ }^{50}$ Theoretically, it is ambiguous whether trust/civic involvement and political institutions are complements or substitutes (see Tabellini (2008) and the discussion in Lowes, Nunn, Robinson, and Weigel (2017)). Heldring (2016) shows with lab-in-the-field experiments that exposure to state institutions has impacted civil society, and in particular norms of obedience to political authority. Individuals close to an abandoned border of historical states are more likely to follow an unenforced rule than individuals just across the border. The state's impact on rule-following led to more violence when the Rwandan government mobilized people for mass killing during the state-organized 1994 genocide but led to less violence when the government pursued peace and rebuilding. Heldring's findings on the ability of the state to mobilize its (more obedient) citizens in historically centralized regions within Rwanda echoes Depetris-Chauvin (2014) finding on the trust toward institutions in centralized regions across Africa.

Finally, there may also be negative angles of precolonial statehood. For example, some of the precolonial African kingdoms were quite extractive, without strong checks-and-balances (Rwanda, Burundi, Swaziland). Slavery was widely practiced in many African kingdoms. Many indigenous African states played a major role in the slave trades, conducting raids inland and selling the captive populations to the Europeans (see the discussion in Section 4).

\footnotetext{
${ }^{50}$ A large literature associates social/civic capital aspects, related among others to trust to economic performance. See, for reviews, Algan and Cahuc (2014), Guiso, Sapienza, and Zingales (2011), and Fernandez (2011).
} 


\subsection{On the Origins of Precolonial Political Centralization}

The corpus of works shedding light on the consequences of political centralization in precolonial Africa has given rise to a vibrant literature that tries to understand why certain regions in Africa came to be populated by state-like organized groups, whereas in other niches of the continent, stateless societies were the norm. These works fit the wider strand of research on the origins of statehood and the factors shaping the emergence and stability of politically complex societies.

In the African context, an array of geographical attributes have been proposed. Bates (1983), adopting a Ricardian view of state formation, famously traced the origins of African states on the welfare gains of the promotion of markets. Fenske (2014) put this conjecture to the test by exploring how ecological diversity predicts the emergence of precolonial states, finding a strong positive relationship. Likewise and working on a global sample of ethnicities, Depetris-Chauvin and Ozak (2015) uncover a positive link between population diversity and statehood, which they attribute to specialization and commerce. Alsan (2015) identifies in the presence of the Tsetse fly an Africa-specific explanation for the origins of statehood. The Tsetse fly, which is unique to Africa transmits a parasite that is harmful to humans and lethal to livestock. Alsan studies climatic variation in ecological suitability for the proliferation of the Tsetse, showing that its intensity limited the ability of Africans to use domesticated animals, generate agricultural surplus, and achieve political centralization. ${ }^{51}$ A complementary explanation of the relatively low level of centralization of African groups lies in the appropriability of agricultural production. Influential scholars, such as Karl Marx and Adam Smith and more recently Jared Diamond, have argued that land quality plays a key role in shaping agricultural productivity, allowing the formation of states to protect agricultural surplus. Mayshar, Moav, Neeman, and Pascali (2015) argue that, since cereals are easier to expropriate than tubers, the demand for security in cereal-producing societies would be stronger compared to tuberreliant ones. Hence, the fact that in Africa the productivity of tubers vis-à-vis cereals is relatively high may have acted as a deterrent for the rise of statehood.

Besides the role of geographic, there are numerous historical examples highlighting the idiosyncratic nature of power consolidation (see, for example, Blouin (2016) work on precolonial statehood in Rwanda). ${ }^{52}$ Osafo-Kwaako and Robinson (2013) discuss examples of statehood in precolonial Africa that cannot be easily explained by common factors. They present cross-ethnicity regression evidence, pointing out an interesting difference between Africa and the rest of the world. Outside Africa, there is a robust association between the mode of subsistence, population densities, and political centralization among preindustrial societies. However, the apparent relationship between state centralization and agricultural intensification

\footnotetext{
${ }^{51}$ Alsan (2015) further shows a significant association between climatic suitability for the Tsetse fly and contemporary development, as reflected in luminosity. However, ecological features may affect contemporary development via numerous channels, and hence, her final sets of results do not necessarily imply a causal chain from ecology to political centralization to development.

${ }^{52}$ Population density in Africa was quite low, and according to most estimates much lower than in other continents. Cherniwchan and Moreno-Cruz (2018) show that the introduction of maize from the Americas raised population density in areas with suitable for maize land (and in turn slave exports).
} 
worldwide breaks down within Africa. Across African groups (recorded in the Ethnographic Atlas), the correlation between dependence on agriculture and a group's degree of political centralization is negligible (0.05), whereas the corresponding correlation with the share of subsistence derived from pastoralism is small (0.12). Likewise, there is a weak positive correlation between population density and centralization in Africa, while the correlation is quite strong in other continents.

\subsection{Other Precolonial Ethnic Traits}

Recent studies have uncovered the lasting legacy of ethnic traits beyond that of precolonial political centralization. These words build on insights of works in cultural anthropology and sociology that using narratives and field work study the quite diverse societal arrangements of African ethnicities (e.g., EvansPritchard (1940), Vansina (1990), Douglas (1962), Bohannon (1958), Fortes (1953), Sahlins and Service (1960), Middleton and Tait (1958)).

\subsubsection{Local Elections}

Giuliano and Nunn (2013) show that ethnicities' tradition of local democracy -that is, having the local leader chosen through consensus rather than via hereditary appointment- is associated with more democratic national institutions and norms today. Bentzen, Hariri, and Robinson (2015) find a similar pattern of institutional persistence, stressing that the relative strength of the indigenous groups within a country matters crucially for persistence.

\subsubsection{Economic Organization}

Michalopoulos, Putterman, and Weil (2018) examine how precolonial subsistence patterns influence contemporary economic and cultural traits. On the eve of the "Scramble for Africa", the continent was populated by societies practicing different types of preindustrial subsistence, from hunter-gatherers to nomadic pastoralists, to shifting and intensive agriculturalists. Five to six generations later, the offspring of these groups are often intermingled, begging the question of whether one's descent regarding precolonial lifeways matters for today's outcomes. After matching the ethnographic record of each group to the ethnic identity of respondents in the DHS, the authors show that the more one's ancestral group's relied on agriculture, the better one's economic outcomes are today. ${ }^{53}$ This long-term correlation is present, controlling for many potentially relevant factors. The authors provide provisional evidence that violence and impatience are higher among descendants of pastoralists. While the authors are unable to separate the "inherent trait" from the "treatment by others" explanations, it seems likely that (at least part) of the disadvantage exhibited by those of non-agricultural ancestry does reflect deep ethnic-specific cultural factors.

\footnotetext{
${ }^{53}$ Alesina, Hohmann, Michalopoulos, and Papaioannou (2018a) offer complementary evidence showing with census-level data spanning 14 countries that social mobility is significantly higher for individuals whose ancestors during the pre-colonial era were more dependent on agriculture.
} 


\subsubsection{Cultural Arrangements}

Alesina, Brioschi, and La Ferrara (2016) explore the role of societal arrangements on the incidence and attitudes toward violence against women. Their analysis uncovers the sizable influence of precolonial socioeconomic conditions on current norms regarding gender roles, family structures, and intra-family violence. In societies where in precolonial times women had an active economic role and/or a bride price was common, men are less prone to gender violence today.

Ashraf, Bau, Nunn, and Voena (2018) investigate how the custom of bride price - a payment by the groom to the family of the bride, prevalent throughout sub-Saharan Africa (and parts of Asia)- influences the success of school-construction programs. Leveraging information from two such programs in Indonesia and Zambia, they document that female enrolment depends crucially on the presence of a bride price tradition. Ethnic groups that traditionally engage in bride price payments show increased female enrolment in schools. Within these ethnic groups, higher female education at marriage is associated with a higher bride price payment received, providing a greater incentive for parents to invest in girls' education. There is no notable increase in education following school construction for girls from ethnicities without a bride price tradition. These results carry lessons for policy, as they suggest that traditional cultural practices are important mediating factors for development policies. From a research standpoint, this work is important as it bridges works on development economics with studies on historical legacies.

Moscona, Nunn, and Robinson (2017a,b) examine the legacy of ethnic kinship, which differed considerably across precolonial Africa. In segmentary lineage ethnicities, economic and social activities center on the family and along patrilineal or matrilineal lineages (where groups usually identify with a mythical ancestor). In line with Robert Putnam's influential conjecture that strong family ties impede the development of general trust, Moscona, Nunn, and Robinson (2017b) find a trust gap for individuals from segmentary lineage ethnicities. Moscona, Nunn, and Robinson (2017a) further show that segmentary lineage societies experience more conflict today.

Lowes (2017) shows that men and women from ethnicities with matrilineal kinship systems, where lineage and inheritance are traced via female family members, cooperate less, though children are, on average, more educated and healthier.

\subsection{Discussion and Future Work}

While the literature has uncovered many interesting patterns on the salience of ethnicity and the legacy of various ethnic-specific institutional and cultural traits, there are still many challenging issues.

Identification The first open issue regards identification. A major task is moving beyond correlations and identifying the one-way impact of ethnic traits on contemporary development proxies. Naturally, obtaining idiosyncratic variation in the incidence of precolonial centralization or cultural traits is not easy. Researchers have increasingly applied state-of-the-art econometric techniques with regional data to improve 
on identification. Conducting the analysis at the subnational level is not a panacea. Some studies employ spatial regression discontinuity designs, essentially comparing adjacent regions along the boundaries of centralized (lineage) and non-centralized (non-lineage) groups to uncover the impact of the former (e.g., Michalopoulos and Papaioannou (2013) and Moscona, Nunn, and Robinson (2017a)). Although the spatial regression discontinuity framework has many merits, it is important to keep in mind that it cannot account for potential differences at the group level and heterogeneity. Moreover, looking at individual boundaries and discontinuities can be quite misleading. For example, as we show in Michalopoulos and Papaioannou (2014), if one was to focus on a single ethnic group partitioned by the national boundary to assess the role of national institutions on local development, she would arrive at different conclusions depending on which group she would have chosen to focus on. Although case-study evidence from particular discontinuities can be illuminating, it should not be interpreted necessarily as uncovering a broad, generalizable pattern.

Concept of Ethnicity A second and deeper issue regards the notion of ethnicity and social cleavages more generally. There is a vigorous debate among anthropologists, Africanists, and social scientists regarding the malleability of ethnicity. On the one hand, scholarship on how colonial and post-independence officials have manipulated the ethnic landscape has stressed the socially constructed and time-varying nature of ethnic identity. On the other hand, a voluminous stream of research treats ethnic groups as relatively stable social units. ${ }^{54}$ Most likely the answer lies somewhere in-between. Nevertheless, the fact that in Africa geographic and epidemiological factors are robust predictors of the degree of contemporary ethnic diversity highlights the sources of stability of these social units (Michalopoulos (2012); Cervellati, Chiovelli, and Esposito (2017)). Recent works, also, point out that in weakly institutionalized societies with few public goods provided by the state, ethnic identification becomes more salient (Eifert, Miguel, and Posner (2010)). We believe that more work is needed to understand the determinants of ethnic identity in Africa (e.g., Habyarimana, Humphreys, Posner, and Weinstein (2009), Posner (2005), Iudice and Michalopoulos (2019)). It would also be interesting to examine the impact of nation-building policies that aim to foster country cohesion (see Blouin and Mukand (2017) and Miguel (2004) for a recent study and an early contribution, respectively).

Measurement Third, there are reasonable concerns about Murdock's mapping of ethnic groups and his classification of political institutions and other ethnic traits. Delineating ethnic boundaries and traits is a heroic task, as there are measurement and conceptual challenges. The ethnographic map (Figure 7a) does not allow for population mixing, and the information reflects ethnic formal and informal traits at a specific point in time (late 19th/early 20th century). Another shortcoming is that Murdock's map does not include information on specific aspects of statehood, such as the extent of commerce or the presence

\footnotetext{
${ }^{54}$ This debate has a venerable intellectual history of two main strands of thought: the primordialists, who treat ethnic groups as deeply rooted, clearly drawn entities (see Geertz (1967)), and the constructivists or instrumentalists, who highlight the contingent and situational character of ethnicity (Barth (1969)).
} 
of courts and police, preventing a systematic examination of which features of political centralization matter for contemporary development. ${ }^{55}$ While classical errors-in-variables yield attenuated and thus conservative estimates, it is likely that noise is systematically correlated to political centralization and economic organization, making it hard to ex-ante sign the bias. To partly account for these concerns, Depetris-Chauvin (2014) digitized a multitude of maps of empires and kingdoms in Africa for the period of CE 1000 to CE 1850 to construct a measure of political centralization that reflects the depth of state history of a given location. Likewise, Lowes (2017) refined Murdock's classification of family structure in DRC using ethnographic maps and information from other anthropologist (Vansina (1990)). Finally, Michalopoulos and Xue (2018) leverage an unutilized resource, namely the oral tradition of roughly 1,000 pre-industrial societies. Utilizing natural language processing techniques, besides providing alternative measures for traits already recorded in the Ethnographic Atlas (that can be used to reduce measurement error), extend the breadth of the information recorded (including the importance of trade) as well as the group coverage. We believe that more work along these lines is needed.

Mechanisms and Interactions Fourth, in its effort to advance on causality, the literature has not paid much attention to heterogeneity, which is likely considerable. Our reading of African history suggests that there are delicate interactions between precolonial ethnic institutional and cultural traits and colonial investments and institutions. For example, Gerring, Ziblatt, VanGorp, and Arevalo (2011) argue that quite often indirect rule was practiced in politically centralized and institutionally advanced societies. And there are also interactions between precolonial traits with the slave trades. Identifying their interplay will improve our understanding of their legacy. Recent works by Blouin (2016) and Heldring (2016) fit this paradigm.

Culture Fifth, future work should explore the origins of other deeply-rooted precolonial cultural norms, as for example, bride price (Corno and Voena (2016)), inheritance rules (La Ferrara and Milazzo (2017)), female genital mutilations and more generally violence against women (Alesina, Brioschi, and La Ferrara (2016)), and cooperation inside and outside close family (Enke (2018), Dunning and Harrison (2010)). Recent works in cultural economics show that such practices have first-order economic effects. It is, therefore, important understanding their origins, especially because shocks and polices may have heterogeneous effects across societies with different cultural norms and practices (e.g., Bau (2018), Corno, Hildebrandt, and Voena (2017)).

\footnotetext{
${ }^{55}$ The Standard Cross-Cultural Sample (SCCS), a very detailed ethnographic record of 187 societies, does include such information, but it has a spatially limited coverage.
} 


\section{Conclusion}

This review weaves together the considerable research conducted over the past two decades linking Africa's past to its current political, social, and economic development. Employing a variety of identification techniques and mostly exploiting within-country variation, the recent literature documents lucidly the historical origins of Africa's regional comparative development. The empirical studies focus on a plethora of historical events, such as indirect colonial rule, missionary investments in schools and clinics, ethnic partitioning, enslavement, and oppression at different time periods. Yet, there are quite a few commonalities. First, there are important advances on measurement with the digitization of colonial and even precolonial sources. Minimizing measurement error of large-scale historical episodes is always challenging, but the careful collection of novel data shows that such seemingly impossible goals can come to fruition. For example, the identification of all chieftaincy families in Sierra Leone from the establishment of indirect rule through today (Acemoglu, Reed, and Robinson (2014)) and the digitization of all shipment data covering the transatlantic slave trade show that comprehensive data work is possible (Nunn (2008)), yielding important insights.

Second, there is a genuine effort to advance on causation. While historical events are hardly random, the literature employs plausible identification techniques, including spatial regression discontinuity, matching, and instrumental variables, to improve on identification. As Europeans' knowledge of the Black Continent during the slave trades and the early colonial period was minimal, the literature has utilized some quasi-random variation, stemming from the artificial colonial border design (Michalopoulos and Papaioannou (2016)) or some other arbitrarily drawn line delineating, for example, colonial concessions to private corporations (Lowes and Montero (2017)).

Third, the emerging corpus is quite interdisciplinary; it builds on insights (and data) from history, political science, sociology, and anthropology. As Mancur Olson has argued, it is difficult to conduct disciplined interdisciplinary research. Nevertheless, we believe that recent research efforts have shown this to be feasible.

As always there are issues that future work is bound to address. To start with, we need better and more refined data on colonial institutions and investments in education, health, and infrastructure, ideally covering all of (sub-Saharan) Africa. Higher-quality data with a wider spatial coverage will not only allow us to improve our understanding quantitatively, but also explore heterogeneity, which is likely to be considerable, but hard to trace when focusing on specific case studies, irrespective of how wellidentified they are. Another area for future research is revisiting George Peter Murdock's mapping of ethnic homelands and the underlying ethnographic information; this is a challenging task, but the works

of Depetris-Chauvin (2014) and Lowes (2017) that updated and refined specific classifications (for subsets of groups) in the Ethnographic Atlas show that it is possible.

So far, researchers have studied these landmark historical events mostly in isolation. This was a 
natural and perhaps a necessary way to start making progress on understanding the shadow of history on contemporary African development. Moreover, the micro-focus was a step forward compared to the hard-to-resolve very macro debates on the supremacy of institutions, geography, or culture in shaping long-run development or the human capital versus institutions and culture debates on colonialism' influence on contemporary development. However, this is only the beginning. A synthesis examining the interplay of the various historical features seems a fruitful research path. For example, the slave trades are related to colonial education investments and also to precolonial ethnic polities. Moreover, the various aspects of colonization are strongly intertwined. But how? Another area where progress is needed is in studying how colonial and precolonial features shaped the political equilibrium at-independence and the post-independence economic trajectories. Future research should examine in detail in which periods colonial and pre-colonial legacies become salient and explore heterogeneity over time. This is interesting as historical features may interact with policies and macroeconomic shocks. Finally, as the research on Africa's economic history and research in development economics have blossomed in parallel, we believe that future work should break the "wall" and examine the role of historical legacies on the success or failure of the various ongoing policy interventions.

The exploration of these and other inquiries should, however, not only come from "outsiders", but also from African scholars. Research on African development entails a "neocolonialist" element, as it mostly reflects the views and biases of European and American (educated) scholars. The next review of the literature should come from an African scholar, working ideally in an African University. 


\section{References}

Abramitzky, R. (2015): "Economics and the Modern Economic Historian," Journal of Economic History, $75(4), 1240-1251$.

Acemoglu, D., D. Cantoni, S. Johnson, and J. A. Robinson (2011): "The Consequences of Radical Reform: The French Revolution," American Economic Review, 101(7), 3286-3307.

Acemoglu, D., I. N. Chaves, P. Osafo-Kwahko, and J. A. Robinson (2016): "Indirect Rule and State Weakness in Africa: Sierra Leone in Comparative Perspective," in African Successes: Sustainable Growth, ed. by S. Edwards, S. Johnson, and D. N. Weil, vol. 4, chap. 9. University of Chicago Press, Chicago, IL.

Acemoglu, D., F. A. Gallego, and J. A. Robinson (2014): "Institutions, Human Capital and Development," Annual Review of Economics, 6(1), 875-912.

Acemoglu, D., T. A. Hassan, and J. A. Robinson (2011): "Social Structure and Development: A Legacy of the Holocaust in Russia," Quarterly Journal of Economics, 126(2), 895-946.

Acemoglu, D., S. Johnson, and J. A. Robinson (2001): "The Colonial Origins of Comparative Development: An Empirical Investigation," American Economic Review, 91(5), 1369-1401.

(2002): "Reversal of Fortune: Geography and Institutions in the Making of the Modern World Income Distribution," Quarterly Journal of Economics, 107(4), 1231-1294.

(2003): “An African Success Story: Botswana," in In Search of Prosperity: Analytical Narratives on Economic Growth, ed. by D. Rodrik. Princeton University Press, Princeton, NJ.

(2005): "Institutions as a Fundamental Cause of Long-Run Growth," in Handbook of Economic Growth, ed. by P. Aghion, and S. N. Durlauf, pp. 109-139. Elsevier, Amsterdam, NL.

Acemoglu, D., S. Naidu, P. Restrepo, and J. A. Robinson (2015): "Democracy Does Cause Growth," Journal of Political Economy, forthcoming.

Acemoglu, D., T. Reed, and J. A. Robinson (2014): "Chiefs: Economic Development and Elite Control of Civil Society in Sierra Leone," Journal of Political Economy, 122(2), 319-368.

Acemoglu, D., and J. A. Robinson (2012): Why Nations Fail: The Origins of Power, Prosperity, and Poverty. Crown Publishers, New York, NY.

Ades, A., And E. L. Glaeser (1999): "Evidence on Growth, Increasing Returns, and the Extent of the Market," Quarterly Journal of Economics, 114(3), 1025-1045. 
Aker, J. C., M. W. Klein, S. A. O'Connell, And M. Yang (2014): "Borders, Ethnicity and Trade," Journal of Development Economics, 107(1), 1-16.

Akyeampong, E., R. H. Bates, N. Nunn, and J. A. Robinson (2014): Africa's Development in Historical Perspective. Cambridge University Press, Cambridge, UK.

Albouy, D. (2012): "The Colonial Origins of Comparative Development: An Empirical Investigation: Comment," American Economic Review, 102(6), 3059-3076.

Alcala, F., And A. Ciccone (2004): "Trade and Productivity," Quarterly Journal of Economics, 119(2), 612-645.

Alder, S. (2015): "Chinese Roads in India: The Effect of Transport Infrastructure on Economic Development," working paper, University of North Carolina at Chapel Hill.

Alesina, A., A. Devleeschauwer, W. Easterly, S. Kurlat, and R. Wacziarg (2003): "Fractionalization," Journal of Economic Growth, 8(2), 155-194.

Alesina, A., W. Easterly, and J. Matuszeski (2011): "Artificial States," Journal of the European Economic Association, 9(2), 246-277.

Alesina, A., S. Hohmann, S. Michalopoulos, and E. Papaionnnou (2018a): "Intergenerational Mobility across Ethnic and Religious Lines in Africa," mimeo, Brown, Harvard and London Business School.

- (2018b): "Intergenerational Mobility in Africa," mimeo, Brown, Harvard and London Business School.

Alesina, A., S. Michalopoulos, and E. Papaioannou (2016): "Ethnic Inequality," Journal of Political Economy, 124(2), 428-488.

Alesina, A., And E. Spolaore (2003): The Size of Nations. MIT Press, Cambridge, MA.

Alesina, A., E. Spolaore, and R. Wacziarg (2000): "Economic Integration and Political Disintegration," American Economic Review, 90(5), 1276-1296.

Alesina, A. F., B. Brioschi, and E. La Ferrara (2016): "Violence against Women: A Cross-Cultural Analysis fo Africa," NBER Working Paper No. 21901.

Alesina, A. F., and P. Giuliano (2015): "Culture and Institutions," Journal of Economic Literature, $53(4), 898-944$. 
Alexopoulou, K., And D. Juif (2017): "Colonial State Formation Without Integration: Tax Capacity and Labour Regimes in Portuguese Mozambique (1890sâĂŞ1970s)," International Review of Social History, 62(2), 215-252.

Algan, Y., and P. Cahuc (2014): "Trust, Well-Being and Growth: New Evidence and Policy Implications," in Handbook of Economic Growth II, ed. by P. Aghion, and S. Durlauf, chap. 2, pp. 49-120. Elsevier, Amsterdam, NL.

Ali, M., O.-H. Fjeldstad, B. Jiang, and A. B. Shifa (2017): "Colonial Legacy, State-Building and the Salience of Ethnicity in Sub-Saharan Africa," mimeo, Syracuse University, Syracuse, NY, forthcoming Economic Journal.

Alsan, M. M. (2015): "The Effect of the TseTse Fly on African Development," American Economic Review, 105(1), 382-410.

Amin, S. (1972): "Underdevelopment and Dependence in Black Africa - Origins and Contemporary Forms," The Journal of Modern African Studies, 10(4), 503-524.

Angeles, L., And A. Elizalde (2017): "Pre-colonial Institutions and Socioeconomic Development: The case of Latin America," Journal of Development Economics, 124(1), 22-40.

Angrist, J., And J.-S. Pischke (2010): "The Credibility Revolution in Empirical Economics: How Better Research Design Is Taking the Con out of Econometrics," Journal of Economic Perspectives, $24(2), 3-30$.

Archibong, B. (2018): "Historical origins of persistent inequality in Nigeria," Oxford Development Studies, 46(3), 325-347.

Archibong, B., and N. Obikili (2018): "Convict Labor and the Costs of Colonial Infrastructure: Evidence from Prisons in British Nigeria, 1920-1938," working paper, Barnard College.

Arvis, J.-F., G. Raballand, and J.-F. Marteau (2007): "The Cost of Being Landlocked : Logistics Costs and Supply Chain Reliability," World Bank, Policy Research Working Paper No. 4258, Washington, D.C.

Ashraf, N., N. Bau, N. Nunn, and A. Voena (2018): "Bride Price and Female Education," Journal of Political Economy, forthcoming.

Ashraf, Q., and O. Galor (2013): "The Out of Africa Hypothesis, Human Genetic Diversity, and Comparative Economic Development," American Economic Review, 103(1), 1-46.

Ashraf, Q. H., and O. Galor (2018): "The Macrogenoeconomics of Comparative Development," Journal of Economic Literature, 56(3), 1119-1155. 
Asiwaju, A. (1985): "The Conceptual Framework," in Partitioned Africans, pp. 1-18. St. Martin Press, New York.

Atkin, D., And D. Donaldson (2017): "Who Is Getting Globalized? The Size and Implications of Intra-national Trade Costs," working paper, MIT Department of Economics, MIT, Cambridge, Ma.

Austen, R. A. (1987): African Economic History: Internal Development and External Dependency. James Curry/Heinemann, London, UK.

Austin, G. (2008): "The Reversal of Fortune Thesis and the Compression of History: Perspectives from African and Comparative Economic History," Journal of International Development, 20(8), 996-1027.

(2010): “African Economic Development and Colonial Legacies," International Development Policy Series, 1, 11-32.

Austin, G., And S. Broadberry (2014): "Introduction: The Rennaissance of African Economic History," Economic History Review, 67(4), 893-906.

Azariadis, C., and J. Stachurski (2005): "Poverty Traps," in The Handbook of Economic Growth, ed. by P. Aghion, and S. N. Durlauf, vol. 1A, chap. 5, pp. 295-384. Elsevier, Amsterdam, NL.

Bai, Y., And J. K. Sing Kung (2015): "Diffusing Knowledge while Spreading God's Message: Protestantism and Economic Prosperity in China, 1840-1920," Journal of the European Economic Association, 13(4), 669-698.

Baldwin, K. (2013): "Why Vote with the Chief? Political Connections and Public Goods Provision in Zambia," American Journal of Political Science, 57(4).

(2016): The Paradox of Traditional Leaders in Democratic Africa. Cambridge University Press, Cambridge, UK.

Baldwin, K., And J. D. Huber (2010): "Economic versus Cultural Differences: Forms of Ethnic Diversity and Public Goods Provision," American Political Science Review, 104(4), 644-662.

Bandyopadhyay, S., and E. Green (2016): "Precolonial Centralisation and Contemporary Development in Uganda," Economic Development and Cultural Change, 64(3).

Banerjee, A., And L. Iyer (2005): "History, Institutions, and Economic Performance: The Legacy of Colonial Land Tenure Systems in India," American Economic Review, 95, 1190-1213.

Bardhan, P. (2016): "State and Development: The Need for a Reappraisal of the Current Literature," Journal of Economic Literature, 54(3), 862-892. 
Barkindo, B. M. (1985): "The Mandara Astride the Nigeria-Cameroon Boundary," in Partitioned Africans, ed. by A. Asiwaju, pp. 155-194. St. Martin's Press, New York, NY.

Barro, R., And J.-W. Lee (2013): "A New Data Set of Educational Attainment in the World, 19502010," Journal of Development Economics, 104(1), 184-198.

Barth, F. (1969): Ethnic Groups and Boundaries: The Social Organization of Cultural Difference. Little, Brown, Boston, MA.

Bates, R. H. (1981): States and Markets in Africa. University of California Press, Berkeley, CA.

- (1983): "Modernization, Ethnic Competition, and the Rationality of Politics in Contemporary Africa," in State versus Ethnic Claims: African Policy Dilemmas, ed. by D. Rothchild, and V. A. Olunsorola. Westview Press, Boulder, CO.

- (2006): "Institutions and Development," Journal of African Economics, 15(1), 10-61.

- (2008): When Things Fell Apart: State Failure in Late-Century Africa. Cambridge University Press, New York, NY.

Bates, R. H., And S. Block (2013): "Revisiting African Agriculture: Institutional Change and Productivity Growth," Journal of Politics, 75(2), 372-384.

(2016): "Institutional Change and the Economic Revival of Africa," in An African Renaissance? Yale University Press, New Haven, CT and London, UK.

BAu, N. (2018): "Can Policy Crowd Out Culture?," working paper, University of Toronto.

Bazzi, S., And M. Gudgeon (2017): "Local Government Proliferation, Diversity, and Conflict," working paper, Boston University, Boston, MA.

Beach, H. P., and C. F. FAhs (1925): World Missionary Atlas. Institute of Social and Religious Research, New York, NY.

Becker, S. O., and L. Woessmann (2009): "Was Weber Wrong? A Human Capital Theory of Protestant Economic History," The Quarterly Journal of Economics, 124(2), 531-596.

Bentzen, J., J. G. Hariri, and J. A. Robinson (2015): "The Indigenous Roots of Representative Democracy," NBER Working Paper No. 21193.

Berger, D., W. Easterly, N. Nunn, and S. Satyanath (2013): "Commercial Imperialism? Political Influence and Trade during the Cold War," American Economic Review, 103(2), 863-896. 
Berman, E. H. (1974): "African Responses to Christian Mission Education," African Studies Review, $17(3), 527-540$.

Berry, S. (1992): "Hegemony on a Shoestring: Indirect Rule and Access to Agricultural Land," Africa: Journal of the International African Institute, 62(3), 327-355.

Bertazzini, M. C. (2018): "The Long-Term Impact Of Italian Colonial Roads In The Horn Of Africa, 1935-2000," Economic History Working Papers 272.

Bertocchi, G. (2016): "The Legacies of Slavery in and out of Africa," IZA Journal of Migration, 5(1), $1-19$.

Bertocchi, G., and A. Dimico (2015): "The Long-Term Determinants of Female HIV Infection in Africa: The Slave Trade, Polygyny, and Sexual Behavior," working paper, University of Modena, Modena, IT.

Besley, T., and T. Persson (2011): Pillars of Prosperity: The Political Economics of Development Clusters. Princeton University Press, Princeton, NJ.

Besley, T., And M. Reynal-Querol (2014): "The Legacy of Historical Conflicts: Evidence from Africa," American Political Science Review, 108(2), 319-336.

Blattman, C., and E. Miguel (2010): “Civil War," Journal of Economic Literature, 48(1), 3-57.

Blouin, A. (2016): "Culture and Contracts: The Historical Legacy of Forced Labour," mimeo University of Toronto.

Blouin, A., And S. Mukand (2017): "Erasing Ethnicity? Propaganda, Nation Building, and Identity in Rwanda," forthcoming, Journal of Political Economy.

Bockstette, V., A. Chanda, and L. Putterman (2002): "States and Markets: The Advantage of an Early Start," Journal of Economic Growth, 7(4), 347-369.

Bohannon, L. (1958): Political Aspects of Tiv Social Organizationchap. 2, pp. 33-67. Routledge, Keegan, and Paul, London, UK.

Bolt, J. (2013): "The Partitioning of Africa," in The History of African Development Textbook, ed. by E. Frankema, and E. Hillbom, chap. 6. African Economic History Network.

Bolt, J., And L. Gardner (2015): "De-compressing History? Pre-colonial Institutions and Local Government Finance in British Colonial Africa," mimeo London School of Economics, London, UK and University of Groningen, Groningen, NL.

Bolt, J., and E. Hillbom (2016): "LongăĂŘterm trends in economic inequality: lessons from colonial Botswana, 1921â̆̆Ş74," The Economic History Review, 69(4), 1255-1284. 
Boone, C. (2003): Political Topographies of the African State: Territorial Authority and Institutional Choice. Cambridge University Press, New York, NY.

Bosker, M., And J. De Ree (2014): "Ethnicity and the Spread of Civil War," Journal of Development Economics, 108, 206-221.

Boxell, L. (2018): "Droughts, Conflict, and the African Slave Trade," mimeo, Stanford University, Economics Department.

Boyd, B. J. (1979): “African Boundary Conflict: An Empirical Study,” African Studies Review, 22(3), $1-14$.

Brecke, P. (1999): "Violent Conflicts 1400 A.D. to the Present in Different Regions of the World," Paper prepared for the 1999 Meeting of the Peace Science Society in Ann Arbor, Michigan.

Breinlich, H., G. Ottaviano, and J. R. Temple (2013): Regional Growth and Regional Declinevol. 2 of Handbook of Economic Growth, chap. 4. Elsevier, Amsterdam, Netherlands.

Broich, T., A. Szirmai, and K. Thomsson (2015): "Precolonial Centralisation, Foreign Aid and Modern State Capacity in Africa," working paper, United Nations University, Tokyo, JP.

Brownlie, I. (1979): African Boundaries: A Legal and Diplomatic Encyclopaedia. Hurst, London, UK.

Burgess, R., R. Jedwab, E. Miguel, A. Morjaria, and G. Padro-I-Miguel (2015): "The Value of Democracy: Evidence from Road Building in Kenya," American Economic Review, 105(6), 1817-1851.

Cagé, J., And V. Rueda (2016): "The Long-Term Effects of the Printing Press in Sub-Saharan Africa," American Economic Journal: Applied Economics, 8(3), 69-99.

- (2017): "Sex and the Mission: The Conflicting Effects of Early Christian Investments on the HIV Epidemic in sub-Saharan Africa," CEPR Discussion Paper 12192.

Caicedo, F. (2017): "The Mission: Economic Persistence, Human Capital Transmission and Culture in South America," working paper, Bonn University, Bonn, DE.

Campante, F., and Q.-A. Do (2014): "Isolated Capital Cities, Accountability, and Corruption: Evidence from US States," American Economic Review, 104(8), 2465-2481.

Campante, F., Q.-A. Do, and B. Guimaraes (2018): "Capital Cities, Conflict, and Misgovernance," American Economic Journal: Applied Economics, forthcoming.

Cantoni, D. (2015): "The Economic Effects of the Protestant Reformation: Testing the Weber Hypothesis in the German Lands," Journal of the European Economic Association, 13(4), 561-598. 
Castello-Climent, A., L. Chaudhary, and A. Mukhopadhyay (2016): "Tertiary Education and Prosperity in Developing Countries: Catholic Missions to Luminosity in India," mimeo, University of Valencia, Valencia, ES.

Cederman, L.-E., S. Rueger, and G. Schvitz (2018): "Redemption through Rebellion: Linking Border Change to Ethnonationalist Conflict," working paper, University of Zurich.

Cederman, L.-E., A. Wimmer, and B. Min (2010): "Why do ethnic groups rebel? New data and analysis.," World Politics, 62(1), 87-119.

Cervellati, M., G. Chiovelli, and E. Esposito (2017): "Bite and Divide: Ancestral Exposure to Malaria and the Emergence and Persistence of Ethnic Diversity in Africa," working paper, London Business School and University of Bologna.

Chamberlain, M. E. (2013): The Scramble for Africa, 3rd ed. Routledge, New York, third edition edn.

Chaves, I., S. L. Engerman, and J. A. Robinson (2014): "Reinventing the Wheel: The Economic Impact of Railways Construction in British Colonial West Africa," in Africa's Development in Historical Perspective, ed. by E. Akyeampong, R. Bates, N. Nunn, and J. A. Robinson. Cambridge University Press, New York, NY.

Cherniwchan, J., and J. Moreno-Cruz (2018): "Maize and Precolonial Africa," Journal of Development Economics, forthcoming.

Chiovelli, G. (2014): "Pre-Colonial Centralization, Colonial Activities and Development in Latin America," mimeo, University of Bologna, Economics Department, Bologna, IT.

Christensen, D., and D. Laitin (2018): Africâ̆ắ́s Unfulfilled Promise and the Path to the Future (. Yale University Press, New Haven, CT.

ChuA, A. (2003): World on Fire: How Exporting Free-Market Democracy Breeds Ethnic Hatred and Global Instability. William Heinemann, London, UK.

Ciccone, A., and M. Jarocinski (2010): "Determinants of Economic Growth: Will Data Tell?," American Economic Journal: Macroeconomics, 2(4), 220-246.

Ciccone, A., and E. Papaioannou (2009): "Human Capital, the Structure of Production, and Growth," Review of Economics and Statistics, 91(1), 66-82.

Clarkson, T. (1839): The History of the Rise, Progress, and Accomplishment of the Abolition of the Slave Trade by British Parliament. Project Gutenberg e-Book 10633. 
Cogneau, D., Y. Dupraz, and S. Mesple-Somps (2018): "African States and Development in Historical Perspective: Colonial Public Finances in British and French West Africa," PSE Working Papers 2018-29.

Cogneau, D., and A. Moradi (2014): "Borders that Divide: Education and Religion in Ghana and Togo since Colonial Times," Journal of Economic History, 74(3), 694-729.

Collier, P. (2007): The Bottom Billion. Oxford University Press, Oxford, UK.

Collier, P., And J. W. Gunning (1999a): "Explaining African Economic Performance," Journal of Economic Literature, 37, 64-111.

(1999b): "Why Has Africa Grown So Slowly?," Journal of Economic Perspectives, 13, 3-22.

Collier, P., and N. Sambanis (2005): Understanding Civil War. Volume 1: Africa. World Bank, Washington, DC.

Collier, P., and A. Venables (2008): "Trade and Economic Performance: Does Africa's Fragmentation Matter?," Paper prepared for the ABCDE Conference.

Collins, D. (1985): "Partitioned Culture Areas and Smuggling: The Hausa and Groundnut Trade across the Nigeria-Niger Boundary up to the 1970s," in Partitioned Africans, ed. by A. Asiwaju, pp. 155-194. St. Martin's Press, New York, NY.

Comin, D., W. Easterly, And E. Gong (2010): "Was the Wealth of Nations Determined in 1000 BC?," American Economic Journal: Macroeconomics, 2(3), 65-97.

Cooper, F. (2002): Africa since 1940: The Past of the Present. Cambridge University Press, Cambridge, UK.

Corno, L., N. Hildebrandt, and A. Voena (2017): "Age of Marriage, Wealther Shocks, and the Direction of Marriage Payments," working paper, University of Chicago, Department of Economics.

Corno, L., and A. Voena (2016): "Selling Daughters: Age of Marraige, Income Shocks, and the Bride Price Tradition," working paper, University of Chicago, Department of Economics.

Crowder, M. (1964): "Indirect Rule: French and British Style," Africa: Journal of the International African Institute, 34(3), 197-205.

Dalton, J. T., And T. C. Leung (2014): "Why Is Polygyny More Prevalent in Western Africa? An African Slave Trade Perspective," Economic Development and Cultural Change, 63(3), 599-632.

Darwin, J. (2012): Unfinished Empire: The Global Expansion of Britain. Penguin Books, Pearson, London, England. 
Davidson, B. (1992): The Black Man's Burden: Africa and the Curse of the Nation-State. James Currey, Oxford, UK.

De Juan, A. (2017): "Traditional Resolution of Land Conflicts: The Survival of Precolonial Dispute Settlement in Burundi," Comparative Political Studies, 50(13), 1835-1868.

DE LA Sierra, R. S. (2018): "On the Origins of the State: Stationary Bandits and Taxation in Eastern Congo," Journal of Political Economy, forthcoming.

Dell, M. (2010): “The Persistent Effects of Peru's Mining Mita,” Econometrica, 78(6), 839-857.

Dell, M., N. Lane, and P. Querubin (2018): "The Historical State, Local Collective Action, and Economic Development in Vietnam," Econometrica, (forthcoming).

Deluca, G., R. Hodler, P. A. Raschky, and M. Valsecchi (2015): "Ethnic Favoritism: An Axiom of Politics?," CESifo Working Paper Series No. 5209.

Depetris-Chauvin, E. (2014): "State History and Contemporary Conflict: Evidence from Sub-Saharan Africa," mimeo, Brown University, Department of Economics, Providence, RI.

Depetris-Chauvin, E., and O. Ozak (2015): "Population Diversity, Division of Labor and the Emergence of Trade and State," working paper, Department of Economics, Southern Methodist University, Dallas, TX.

Desmet, K., I. Ortuno-Ortin, and R. Wacziarg (2012): "The Political Economy of Ethnolinguistic Cleavages," Journal of Development Economics, 97(2), 322-338.

Desmet, K., I. OrtuÃso-Ortãjn, and R. Wacziarg (2017): "Culture, Ethnicity and Diversity," American Economic Review, 107(9), 2479-2513.

Diamond, J. (1997): Guns, Germs, and Steel. The Fates of Human Societies. W. W. Norton and Co., New York, NY.

Diamond, J., And J. A. Robinson (2010): Natural Experiments of History. Harvard University Press, Cambridge, MA.

Dickens, A. (2018): "Ethnolinguistic Favoritism in African Politics," American Economic Journal: Applied Economics, 10(3), 370-402.

Dippel, C. (2014): "Forced Coexistence and Economic Development: Evidence from Native American Reservations," Econometrica, 82(6), 2131-2165.

Dittmar, J. (2011): "Information Technology and Economic Change: The Impact of the Printing Press," Quarterly Journal of Economics, 126(3), 1133-1172. 
Donaldson, D. (2015): "The Gains from Market Integration," Annual Review of Economics, 7, 619-647. (2018): "Railroads of the Raj: Estimating the Impact of Transportation Infrastructure," American Economic Review, 108(4-5), 899-934.

Donaldson, D., and R. Hornbeck (2016): "Railroads and American Economic Growth: A Market Access Approach," Quarterly Journal of Economics, 131(2), 799-858.

Donaldson, D., And A. Storeygard (2016): "The View from Above: Applications of Satellite Data in Economics," Journal of Economic Perspectives, 30(4), 171-198.

Douglas, M. (1962): "Lele Economy Compared with the Bushong: A Study of Economic Backwardness," in Markets in Africa, ed. by P. Bohannan, and G. Dalton, pp. 211-233. Northwestern University Press, Evanston, IL.

Dowden, R. (2008): Africa: Altered States, Ordinary Miracles. Portobello Books Ltd., London, UK.

Doyle, S., F. Meier zu Selhausen, and J. Weisdorf (2018): "The Blessings of Medicine? Patient Characteristics and Heath Outcomes in a Ugandan Mission Hospital, 1908-1970," mimeo, University of Sussex.

Dunning, T., and L. Harrison (2010): "Cross-Cutting Cleavages and Ethnic Voting: An Experimental Study of Couisnage in Mali," American Political Science Review, 104(1), 21-39.

Dupas, P., And E. Miguel (2017): "Impacts and Determinants of Health Levels in Low-Income Countries," in Handbook of Field Experiments,, ed. by E. Dulo, and A. Banerjee, vol. 2, chap. 1, pp. 3-94. Elsevier, Amsterdam, Holland.

Dupraz, Y. (2015): "French and British Colonial Legacies in Education: A Natural Experiment in Cameroon," mimeo, Paris School of Economics, Paris, FR.

Durlauf, S. N. (2009): "The Rise and Fall of Cross-Country Growth Regressions," History of Political Economy, Supplement 1, 315-333.

Durlauf, S. N., P. A. Johnson, and J. R. Temple (2005): Growth Econometricsvol. 1 of Handbook of Economic Growth, chap. 8, pp. 555-677. Elsevier, Amsterdam, Netherlands.

Durlauf, S. N., And I. Shaoshadze (2014): Poverty TrapsEncyclopedia of World Poverty. Sage Publishers.

Easterly, W. (2003): “Can Foreign Aid Buy Growth?," Journal of Economic Perspectives, 17(3), 23-48. 
- (2005): "National Policies and Economic Growth: A Reappraisal," in Handbook of Economic Growth, ed. by P. Aghion, and S. N. Durlauf, vol. 1A, chap. 15, pp. 1015-1059. Elsevier, Amsterdam, NL.

(2008): “Can the West Save Africa?," Journal of Economic Literature, 47(2), 373-447.

Easterly, W., And R. Levine (1997): "Africa's Growth Tragedy: Policies and Ethnic Divisions," Quarterly Journal of Economics, 112(4), 1203-1250.

(2016): "The European Origins of Economic Development," Journal of Economic Growth, 21(3), $225-257$.

Eaton, J., and S. Kortum (2002): “Technology, Geography, and Trade,” Econometrica, 70(5), 17411779 .

Edlund, L., And H. Ku (2011): "The African Slave Trade and the Curious Case of General Polygyny," mimeo, Columbia University, New York, NY.

Eifert, B., E. Miguel, and D. Posner (2010): "Political Competition and Ethnic Identification in Africa," American Journal of Political Science, 54(1), 495-510.

Eltis, D., S. D. Behrendt, D. Richardson, and H. S. Klein (1999): The Trans-Atlantic Slave Trade: A Database on CD-ROMEH.net, Cambridge and New York, Cambridge University Press.

Engerman, S. L., and K. L. Sokoloff (1997): "Factor Endowments, Institutions, and Differential Paths of Growth among New World Economies," in How Latin America Fell Behind, ed. by S. Haber, pp. 260-304. Stanford University Press, Stanford, CA.

(2002): "Factor Endowments, Inequality, and Paths of Development among New World Economies," NBER Working Paper No. 9259.

Englebert, P. (2000): "Precolonial Institutions, Post-Colonial States, and Economic Development in Tropical Africa," Political Research Quarterly, 53(7), 7-36.

- (2002): "Born-again Buganda or the Limits of Traditional Resurgence in Africa," Journal of Modern African Studies, 40(3), 345-368.

(2009): Africa: Unity, Sovereignty, and Sorrow. Lynne Rienner Publishers, Boulder, CO.

Englebert, P., S. Tarango, and M. Carter (2002): "Dismemberment and Suffocation: A Contribution to the Debate on African Boundaries," Comparative Political Studies, 35(10), 1093-1118.

Enke, B. (2018): "Kinship, Cooperation, and the Evolution of Moral Systems," working paper, Harvard University, Department of Economics. 
Evans-Pritchard, E. E. (1940): The Nuer. Claredon, Oxford.

FAGE, J. D. (1980): "Slaves and Society in Western Africa, c. 1445 - c. 1700," Journal of African History, 21(2), 289-310.

Fenske, J. (2013): "Does Land Abundance Explain African Institutions?," Economic Journal, 123(573), $1363-1390$.

(2014): "Ecology, Trade, and States in Pre-colonial Africa," Journal of the European Economic Association, 12(3), 612-640.

(2015): "African Polygamy: Past and Present," Journal of Development Economics, 117(2), $58-73$.

Fenske, J., And N. Kala (2015): "Climate and the Slave Trade," Journal of Development Economics, $115,19-32$.

- (2017): “1807: Economic Shocks, Conflict, and the Slave Trade," Journal of Development Economics, 126, 66-76.

Fernandez, R. (2011): "Does Culture Matter?," in Handbook of Social Economics, ed. by J. Benhabib, M. O. Jackson, and A. Bisin, vol. 1A, chap. 11, pp. 481-510. Elsevier, Amsterdam, NL.

Feyrer, J., And B. Sacerdote (2009): "Colonialism and Modern Income: Islands as Natural Experiments," Review of Economics and Statistics, 91(2), 245-262.

Fieldhouse, D. K. (1999): The West and the Third World: Trade, Colonialism, Dependence and Development (Oxford, 1999. Blackwell, Oxford, England.

Fortes, M. (1953): "The Structure of Unilineal Descent Groups," American anthropologist, 55(1), 17-41.

Fortes, M., and E. Evans-Pritchard (1940): African Political Systems. Oxford University Press, Oxford, UK.

Fourie, J. (2013): "The Rise of Education in Africa," in The History of African Deelopment Textbook, ed. by E. Frankema, and E. Hillbom, chap. 8. African Economic History Network.

(2016): "The data revolution in African economic history," Journal of Interdisciplinary History, $47(2), 193-212$.

Fourie, J., and C. Swanepoel (2015): "When selection trumps persistence: The lasting effect of missionary education in South Africa," Tijdschrift voor Sociale en Economische Geschiedenis, 12(1), 1-29. 
Franck, R., And I. Rainer (2012): "Does the Leader's Ethnicity Matter? Ethnic Favoritism, Education and Health in Sub-Saharan Africa," American Political Science Review, 106(2), 294-325.

Frankema, E., and E. Hillbom (2013): The History of African Development. African Economic History Network.

Frankema, E., and M. van Waijenburg (2014): "Metropolitan Blueprints of Colonial Taxation? Lessons from Fiscal Capacity Building in British and French Africa, c. 1880-1940," Journal of African History, 55(3), 371-400.

Frankema, E., J. G. Williamson, and P. Woltjer (2017): "An Economic Rationale for the African Scramble: The Commercial Transition and the Commodity Price Boom of 1845-1885," NBER Working Paper No. 21213.

Frankema, E. H. (2012): "The origins of formal education in sub-Saharan Africa: was British rule more benign? European Review of Economic History 16(4): 335-55.," European Review of Economic Histrory, $16(4), 335-355$.

From Slavery to Aid Politics, L., and E. In the Nigerien Sahel 1800ÂĂŞ2000 (2015): Benedetta Rossi. Cambridge University Press, Cambridge, England.

Fuchs-Schundeln, N., and T. A. Hassan (2015): "Natural Experiments in Macroeconomics," in Handbook of Macroeconomics, ed. by J. B. Taylor, and H. Uhlig, vol. 2. Elsevier, Amsterdam, NL.

Gallagher, J., and R. Robinson (1953): "The Imperialsim of Free Trade," The Economic History Review, 6(1), 1-15.

Gallego, F. A., and R. D. Woodberry (2010): "Christian Missionaries and Education in Former African Colonies: How Competition Mattered," Journal of African Economics, 19(3), 294-329.

Galor, O. (2005): "From Stagnation to Growth: Unified Growth Theory," in Handbook of Economic Growth, ed. by P. Aghion, and S. Durlauf. Elsevier, Amsterdam, NL.

Garcia-Ponce, O., and L. Wantchekon (2011): "Echoes of Colonial Repression: The Long-Term Effects of the 1947 Revolt upon Political Attitudes in Madagascar," working paper, Princeton University, Princeton, NJ.

Gardner, L. (2012): Taxing colonial Africa: the Political Economy of British Imperialism. Oxford University Press.

Geertz, C. (1967): Old Societies and New States: The Quest for Modernity in Asia and Africa. Free Press, New York, NY. 
Gennaioli, N., And I. Rainer (2006): "Precolonial Centralization and Institutional Quality in Africa," in Institutions and Norms in Economic Development, ed. by M. Gradstein, and K. Konrad. MIT Press, Cambridge, MA.

- (2007): "The Modern Impact of Precolonial Centralization in Africa," Journal of Economic Growth, 12(3), 185-234.

Gerring, J., D. Ziblatt, J. VanGorp, and J. Arevalo (2011): "An Institutional Theory of Direct and Indirect Rule," World Politics, 63(3), 377-433.

Giuliano, P., and N. Nunn (2013): "The Transmission of Democracy: From the Village to the Nation State," American Economic Review, Papers and Proceedings, 103(3), 86-92.

Glaeser, E. L., and J. D. Gottlieb (2009): "The Wealth of Cities: Agglomeration Economies and Spatial Equilibrium in the United States," Journal of Economic Literature, 47(4), 983-1028.

Glaeser, E. L., R. La Porta, F. Lopez-De-Silanes, and A. Shleifer (2004): "Do Institutions Cause Growth?," Journal of Economic Growth, 9(3), 271-303.

Glennerster, R., E. Miguel, and A. Rothenberg (2013): "Collective Action in Diverse Sierra Leone Communities," Economic Journal, 123(568), 285-316.

Goemans, H., and K. Schultz (2017): "The Politics of Territorial Disputes: A Geospatial Approach Applied to Africa," International Organization, 71, 31-64.

Goldstein, M., and C. Udry (2008): "The Profits of Power: Land Rights and Agricultural Investment in Ghana," Journal of Political Economy, 116(6), 981-1022.

Green, E. (2013): "Explaining African Ethnic Diversity," International Political Science Review, 34(2), $235-253$.

Grosfeld, I., A. Rodnyansky, and E. Zhuravskaya (2013): "Persistent Anti-market Culture: A Legacy of the Pale of Settlement after the Holocaust," American Economic Journal: Economic Policy, $5(3), 189-226$.

Grosjean, P. (2011): "Long Term Institutional Persistence: Ottoman Rule and Financial Development in the Regions of Europe," Journal of Comparative Economics, 39(2), 1-16.

Guiso, L., P. Sapienza, and L. Zingales (2009): "Cultural Biases in Economic Exchange," Quarterly Journal of Economics, 124(3), 1095-1131.

- (2011): "Civic Capital as the Missing Link," in Handbook of Social Economics, ed. by J. Benhabib, A. Bisin, and M. Jackson, vol. 1, pp. 417-480. Elsevier, Amsterdam, NL. 
- (2016): "Long Term Persistence," Journal of the European Economic Association, 14(6), 14011436, Journal of the European Economic Association.

Habyarimana, J., M. Humphreys, D. Posner, and J. M. Weinstein (2009): Coethnicity: Diversity and Dilemmas of Collective Action. Russel Saga Foundation Press, New York, NY.

Hall, R. E., And C. I. Jones (1999): "Why Do Some Countries Produce So Much More Output per Worker than Others?," Quarterly Journal of Economics, 114(1), 83-116.

Hanushek, E. A., And D. D. Kimko (2000): "Schooling, Labor-Force Quality, and the Growth of Nations," American Economic Review, 90(5), 1184-1208.

Harari, M., and E. La Ferrara (2014): "Conflict, Climate and Cells: A Disaggregated Analysis," mimeo, MIT, Cambridge, MA, and Bocconi University, Millan, IT.

Hegre, H., and N. Sambanis (2006): "Sensitivity Analysis of Empirical Results on Civil War Onset," Journal of Conflict Resolution, 50(4), 508-535.

Heldring, L. (2016): "Violence and the State: Evidence from Rwanda's 'Decade of Atrocities'," mimeo, Harvard University, Cambridge, MA.

Heldring, L., And J. A. Robinson (2012): "Colonialism and Development in Africa," NBER Working Paper No. 18566.

Henderson, V., T. Squires, A. Storeygard, and D. Weil (2018): "The Global Distribution of Economic Activity: Nature, History and the Role of Trade," Quarterly Journal of Economics, 133(1), $357-406$.

Henderson, V. J., A. Storeygard, and D. N. Weil (2012): "Measuring Economic Growth from Outer Space," American Economic Review, 102(2), 994-1028.

Herbst, J. (2000): States and Power in Africa. Princeton University Press, Princeton, NJ.

Herranz-Loncan, A., and J. Fourie (2017): "For the public benefit? Railways in the British Cape Colony," European Review of Economic History, 22(1), 73-100.

Hilbom, E. (2014): “Cattle, Diamonds and Institutions: Main drivers of Botswana's economic development, 1850 to present," Journal of International Development, 26(2), 155-176.

Hintze, O. (1970): The Historical Essays of Otto Hintzechap. "Military Organization and the Organization of the State", pp. 175-215. Oxford University Press, Oxford, UK.

HJort, J. (2010): "Pre-Colonial Culture, Post-Colonial Economic Success? The Tswana and the African Economic Miracle," Economic History Review, 63(3), 688-709. 
Hobson, J. A. (1902): Imperialism. A Study. James Pott and Company, New York, NY.

Hochschild, A. (1998): King Leopold's Ghost: A Story of Greed, Terror, and Heroism in Colonial Africa. Houghton Mifflin Harcourt, New York, NY.

Hodler, R., And P. A. Raschky (2014): "Regional Favoritism," Quarterly Journal of Economics, 129(2), 995-1033.

Hopkins, A. (2009): "The New Economic History of Africa," Journal of African History, 50(2), 155-177.

Huillery, E. (2009): "History Matters: The Long Term Impact of Colonial Public Investments in French West Africa," American Economic Journal: Applied Economics, 1(2), 176-215.

- (2011): "The Long-Term Impact of European Settlement within Former French West Africa: Did Prosperous Areas Fall Behind?," Journal of African Economics, 20(2), 263-311.

Humphreys, M., And H. A. Mohamed (2005): "Senegal and Mali: A Comparative Study of Rebellions in West Africa," in Understanding Civil War: Evidence and Analysis, Vol. 1 Africa, ed. by P. Collier, and N. Sambanis. World Bank, Washington, DC.

Hunziker, P., C. Muller-Crepon, and L.-E. Cederman (2018): "Roads to Rule, Roads to Rebel: Relational State Capacity and Conict in Africa," workinig paper, University of Zurich.

Inikori, J. E., and S. L. Engerman (1992): The Atlantic Slave Trade: Effects on Economies, Societies and Peoples in Africa, the Americas and Europe. Duke University Press, Durham, NC.

Iudice, M., And S. Michalopoulos (2019): "On the Transmission of Ethnic Identity in Africa," working paper, Brown University.

Iwanowsky, M. (2018): "The Effects of Migration and Ethnicity on African Economic Development," working paper, Ludwig-Maximilians-University Munich.

IYeR, L. (2010): "Direct versus Indirect Colonial Rule in India: Long-Term Consequences," Review of Economics and Statistics, 92(4), 693-713.

Jedwab, R., F. Meier zu Selhousen, and A. Moradi (2017): "The Economics of Missionary Expansion and the Compression of History," mimeo, University of Sussex, Sussex, UK, and George Washington University, Washington, DC.

Jedwab, R., And A. Moradi (2016): "The Permanent Effects of Transportation Revolutions in Poor Countries: Evidence from Africa," Review of Economics and Statistics, 98(2), 268-284. 
Jedwab, R., and A. Storeygard (2016): "Economic and Political Factors in Infrastructure Investment: Evidence from Railroads and Roads in Africa 1960-2015," mimeo, George Washington University. Washington, DC, and Tufts University, Medford, MA.

- (2017): "The Heterogeneous Effects of Transportation Investments: Evidence from Sub-Saharan Africa 1960-2010," mimeo, Tufts University, Medford, MA, and George Washington University, Washington, DC.

Jerven, M. (2014): "A West African experiment: constructing a GDP series for colonial Ghana, 1891âĂŞ1950," The Economic History Review.

Jerven, M., G. Austin, E. Green, C. Uche, E. Frankema, J. Fourie, J. E. Inikori, A. Moradi, and E. Hillbom (2012): "Moving Forward in African Economic History: Bridging the Gap between Methods and Sources," African Economic History Network Working Paper 1.

Johnson, A. W., and T. Earle (2000): The Evolution of Human Societies: From Foraging Group to Agrarian State. Stanford University Press, Stanford, CA.

Johnson, B. H. (1967): "The Location of Christian Missions in Africa," Geographical Review, 57(2), $168-202$.

Kalyvas, S. (2007): "Civil Wars," in Handbook of Political Science, ed. by C. Boix, and S. Stokes, pp. 416-434. Oxford University Press, New York.

Kerby, E., R. Jedwab, And A. Moradi (2017): "History, Path Dependence and Development: Evidence from Colonial Railroads, Settlers and Cities in Kenya," Economic Journal, 127(603), 1217-1729.

Koponen, J. (1994): Development for exploitation : German colonial policies in Mainland Tanzania, 1884-1914. Finnish Historical Society studia historica, Helsinki.

Kudo, Y. (2017): "Missionary Influence on Marriage Practices: Evidence from the Livingstonia Mission in Malawi," Journal of African Economies, 26(3), 372-431.

La Ferrara, E., and A. Milazzo (2017): "Customary Norms, Inheritance and Human Capital. Evidence from a Reform of the Matrilineal System in Ghana," American Economic Journal: Applied Economics, $9(4), 166-185$.

La Porta, R., F. Lopez-De-Silanes, and A. Shleifer (2008): "The Economic Consequences of Legal Origins," Journal of Economic Literature, 46(2), 285-332.

La Porta, R., F. Lopez-de-Silanes, A. Shleifer, and R. Vishny (1997): "Legal Determinants of External Finance," Journal of Finance, 52(3), 1131-1150. 
— (1998): "Law and Finance," Journal of Political Economy, 106(6), 1113-1155.

(1999): "The Quality of Government," Journal of Law Economics and Organization, 15(1), 222279.

Laitin, D. D., and R. Ramachandran (2016): "Language Policy and Human Development," American Political Science Review, 110(3), 457-480.

- (2018): "Linguistic Diversity, Official Language Choce and Nation Building: Theory and Evidence," working paper, Stanford University.

Laitin, D. D., R. Ramachandran, and S. L. Walter (2017): "The Legacy of Colonial Language Policies and their Impact on Student Learning: Evidence from an Experimental Program in Cameroon," Economic Development and Cultural Change, forthcoming.

Lamoreaux, N. R. (2018): "The Future of Economic History Must Be Interdisciplinary," Journal of Economic History, 75(4), 1251-1257.

Landes, D. S. (1998): The Wealth and Poverty of Nations: Why Some Are So Rich and Some So Poor. W. W. Norton, New York, NY.

Lange, M. (2009): Lineages of Despotism and Development: British Colonialism and State Power. University of Chicago Press, Chicago, IL.

LARCOM, S. (2013): “Accounting for Legal Pluralism: The Impact of Pre-Colonial Institutions on Crime," Law and Development Review, 6(1), 25-59.

LAW, R. (1991): The Slave Coast of West Africa, 1550-1750: The Impact of the Atlantic Slave Trade on an African Society. Clarednon Press, Oxford, UK.

Lechler, M., And L. MCNamee (2018): "Indirect Colonial Rule Undermines Support for Democracy: Evidence From a Natural Experiment in Namibia," Comparative Political Studies, forthcoming.

Lee, D. S., And T. Lemieux (2010): "Regression Discontinuity Designs in Economics," Journal of Economic Literature, 48(2), 281-355.

Levine, R. (2005): "Finance and Growth: Theory and Evidence," in Handbook of Economic Growth, ed. by P. Aghion, and S. N. Durlauf, vol. 1, chap. 12, pp. 865-934. Elsevier, Amsterdam, NL.

Levine, R., C. Lin, And W. Xie (2017): "The Origins of Financial Development: How the African Slave Trade Continues to Influence Modern Finance," NBER Working Paper No. 23800.

Logan, C. (2011): "The Roots of Resilience: Exploring Popular Support for African Traditional Authorities," Afrobarometer Working Paper No. 128. 
Lovejoy, P. E. (2004): "Slavery on the Frontiers of Islam," .

Lowes, S. (2017): "Matrilineal Kinship and Spousal Cooperation: Evidence from the Matrilineal Belt," mimeo, Bocconi University, Milan, IT.

Lowes, S., And E. Montero (2017): "Blood Rubber: The Effects of Labor Coercion on Development and Culture in the Democratic Republic of Congo," working paper, Harvard University, Department of Economics, Cambridge, MA.

(2018): "The Legacy of Colonial Medicine in Central Africa," mimeo Bocconi University.

Lowes, S., N. Nunn, J. A. Robinson, and J. Weigel (2017): "The Evolution of Culture and Institutions: Evidence from the Kuba Kingdom,” Econometrica, 85(4), 1065-1091.

Mamdani, M. (1996): Citizen and Subject. James Currey, London, UK.

Manning, P. (2013): "Slavery and Slave Trade in West Africa, 1450-1930," in The History of African Development Textbook, ed. by E. Frankema, and E. Hillbom, chap. 4. African Economic History Network.

Mantovanelli, F. (2013): "The Protestant Legacy: Missions and Literacy in India," mimeo, Boston College.

Mantovanelli, F. G. (2014): "Christian Missions, HIV and Sexual Behavior in Sub-Saharan Africa," mimeo, Boston College, Department of Economics.

Mayshar, J., O. Moav, Z. Neeman, and L. Pascali (2015): "Cereals, Appropriability and Hierarchy," CEPR Discussion Paper 10742.

Meier zu Selhausen, F., M. H. D. van Leeuwen, and J. L. Weisdorf (2018): "Social mobility among Christian Africans: evidence from Anglican marriage registers in Uganda, 1895âĂŞ2011," The European Economic History Review, 71(4), 1291-1321.

Meier zu Selhausen, F., and J. Weisdorf (2016): “A Colonial Legacy of African Gender Inequality? Evidence from Christian Kampala, 1895-2011," Economic History Review, 22(1), 130-157.

Meredith, M. (2005): The State of Africa: A History of the Continent since Independence. Free Press, London, UK.

Michalopoulos, S. (2012): "The Origins of Ethnolinguistic Diversity," American Economic Review, 102(4), 1508-1539.

Michalopoulos, S., A. Naghavi, and G. Prarolo (2018): "Trade and Geography in the Origins and Spread of Islam," Economic Journal, forthcoming. 
Michalopoulos, S., and E. Papaioannou (2013): "Pre-colonial Ethnic Institutions and Contemporary African Development," Econometrica, 81(1), 113-152.

- (2014): "National Institutions and Subnational Development in Africa," Quarterly Journal of Economics, 129(1), 151-213.

(2015a): "Further Evidence on the Link between Precolonial Political Centralization and Contemporary African Development," Economic Letters, 126(1), 57-62.

(2015b): "On the Ethnic Origins of African Development: Traditional Chiefs and Pre-colonial Political Centralization," Academy of Management (Perspectives), 29(1), 32-71.

- (2016): "The Long-Run Effects of the Scramble for Africa," American Economic Review, 106(7), 1802-48.

(2017): "The Long Economic and Political Shadow of History," VOXEU, London, UK.

(2018): "Spatial Patterns of Development; A Meso Approach," Annual Review of Economics, 10, $383-410$.

Michalopoulos, S., L. Putterman, and D. Weil (2018): "The Influence of Ancestral Lifeways on Individual Economic Outcomes in Sub-Saharan Africa," Journal of European Economic Association, forthcoming.

Michalopoulos, S., And M. Xue (2018): "Folklore," working paper, Brown University.

Middleton, J., And D. Tait (1958): Tribes without Rulers. Routledge and Kegan, London, UK.

Miescher, S. (2018): A Dam for Africa: The Volta River Project and Modernization in Ghana. forthcoming.

Migdal, J. S. (1988): Strong Societies and Weak States: State-Society Relations and State Capabilities in the Third World. Princeton University Press, Princeton, NJ.

Miguel, E. (2004): "Tribe or Nation? Nation-Building and Public Goods in Kenya versus Tanzania," World Politics, 56(3), 327-362.

Montalvo, J.-G., and M. Reynal-Querol (2005): "Ethnic Polarization, Potential Conflict, and Civil Wars," American Economic Review, 95(3), 796-816.

MorAdi, A. (2009): "Towards an objective account of nutrition and health in colonial Kenya: a study of stature in African army recruits and civilians, 1880âĂŞ1980," Journal of Economic History, 69(3), $719-754$. 
Moscona, J., N. Nunn, and J. A. Robinson (2017a): "Keeping It in the Family: Lineage Organization and the Scope of Trust in Sub-Saharan Africa," American Economic Review Papers and Proceedings, $107(5), 565-571$.

— (2017b): "Social Structure and Conflict: Evidence from Sub-Saharan Africa," mimeo, Harvard University, Cambridge, MA.

Murdock, G. P. (1959): Africa: Its Peoples and their Culture History. McGraw-Hill, New York, NY. (1967): Ethnographic Atlas: A Summary. University of Pittsburgh Press, Pittsburgh, PA.

Nunn, N. (2007): "Relationship-Specificity, Incomplete Contracts and the Pattern of Trade," Quarterly Journal of Economics, 122(2), 569-600.

- (2008): "The Long Term Effects of Africa's Slave Trades," Quarterly Journal of Economics, 123(1), 139-176.

- (2010): "Religious Conversion in Colonial Africa," American Economic Review Papers and Proceedings, 100(2), 147-152.

(2012): "Culture and the Historical Process," Economic History of Developing Regions, 27(S1), $108-126$.

(2014a): "Gender and Missionary Influence in Colonial Africa," in Africa's Development in Historical Perspective, ed. by E. Akyeampong, R. Bates, N. Nunn, and J. A. Robinson, pp. 489-512. Cambridge University Press, New York, NY.

(2014b): "Historical Development," in Handbook of Economic Growth, ed. by P. Aghion, and S. Durlauf, vol. 2, chap. 7, pp. 347-402. Elsevier, Amsterdam, NL.

(2017): "Understanding the Long-Run Effects of Africa's Slave Trades," in The Long Economic and Political Shadow of History, Volume II: Africa, Asia, and Oceania, ed. by S. Michalopoulos, and E. Papaioannou, chap. 2, pp. 37-49. VOXEU, London, UK.

Nunn, N., And D. Puga (2012): "Ruggedness: The Blessing of Bad Geography in Africa," Review of Economics and Statistics, 94(1), 20-36.

Nunn, N., And N. QIAn (2011): "The Potato's Contribution to Population and Urbanization: Evidence from a Historical Experiment," Quarterly Journal of Economics, 126(2), 593-650.

Nunn, N., and L. Wantchekon (2011): "The Slave Trade and the Origins of Mistrust in Africa," American Economic Review, 101(7), 3221-3252. 
Obikili, N. (2016): "The Impact of the Slave Trade on Literacy in West Africa: Evidence from the Colonial Era," Journal of African Economics, 25(1), 1-27.

Okoye, D., and R. Pongou (2014): "Historical Missionary Activity, Schooling, and the Reversal of Fortunes: Evidence from Nigeria," unpublished paper, University of Ottawa, Ottawa, CA, and Dalhousie University, Halifax. CA.

- (2015): "Sea Change: The Competing Long-Run Impacts of the Transatlantic Slave Trade and Missionary Activity in Africa," working paper, Dalhousie University, Halifax, CA.

Okoye, D., R. Pongou, and T. Yokossi (2017): "On the Dispensability of New Transportation Technologies: Evidence from the Heterogeneous Impact of Railroads in Nigeria," working paper, MIT, Cambridge, MA.

Osafo-Kwahko, P., And J. A. Robinson (2013): "Political Centralization in Pre-colonial Africa," Journal of Comparative Economics, 41(1), 534-564.

Pakenham, T. (1991): The Scramble for Africa. Abacus, London, UK.

Papaiohnnou, E., And G. Siourounis (2008): "Democratization and Growth," Economic Journal, $118(10), 1520-1551$.

Pascali, L. (2017): "The Wind of Change: Maritime Technology, Trade and Economic Development," American Economic Review, 107(9), 2821-2854.

Perez-Cervantes, F. (2014): "Railroads and Economic Growth: A Trade Policy Approach," Working Papers, Banco de Mexico, No. 2014-14.

Pierce, L., And J. A. Snyder (2017): "The Historical Slave Trade and Firm Access to Finance in Africa," Review of Financial Studies, 31(1), 142-174.

Pinkovskiy, M. (2017): "Growth Discontinuities at Borders," Journal of Economic Growth, 22(2), 145192.

Pinkovskiy, M., and X. Sala-I-Martin (2014): "Africa is on Time," Journal of Economic Growth, $19(3), 311-338$.

Pinkovskiy, M., and X. Sala-I-Martin (2016): "Lights, Camera,... Income!: Estimating Poverty Using National Accounts, Survey Means, and Lights," Quarterly Journal of Economics, 131(2), 579-631.

Posner, D. N. (2005): Institutions and Ethnic Politics in Africa. Cambridge University Press, New York, NY. 
Putterman, L., and D. N. Weil (2010): "Post-1500 Population Flows and the Long-Run Determinants of Economic Growth and Inequality," Quarterly Journal of Economics, 125(4), 1627-1682.

Rajan, R. G., and L. Zingales (1998): "Financial Dependence and Growth," American Economic Review, 88(3), 559-586.

RAmachandran, R. (2017): "Language use in education and human capital formation: Evidence from the Ethiopian educational reform," World Development, 98(1), 195-213.

Redding, S., And M. Turner (2015): "Transportation Costs and the Spatial Organization of Economic Activity," in Handbook of Urban and Regional Economics, ed. by G. Duranton, V. Henderson, and W. Strange, chap. 20, pp. 1339-1398. Elsevier, Amsterdam, NL.

Renner, F. A. (1985): "Ethnic Affinity: Partition and Political Integration in Senegambia," in Partitioned Africans: Ethnic Relations across Africa's International Boundaries 1884-1984, ed. by A. Asiwaju, pp. 71-86. C. Hurst \& Co. and University of Lagos Press, London, UK.

Robinson, J. A. (2001): "Social Identity, Inequality, and Conflict," Economics of Governance, 2(2), 85-99.

(2002): "States and Power in Africa: Comparative Lessons in Authority and Control by Jeffrey I. Herbst: A Review Essay," Journal of Economic Literature, 40(3), 510-519.

Rodney, W. (1972): How Europe Underdeveloped Africa. Bogle-L'Ouverture Publications, London, UK.

- (1981): How Europe Underdeveloped Africa, rev. ed. Howard University Press, Washington, DC.

Romalis, J. (2004): "Factor Proportions and the Structure of Commodity Trade," American Economic Review, 94(1), 67-97.

Roome, W. R. M. (1924): "Ethnographic Survey of Africa: Showing the Tribes and Languages an the Stations of Missionary Societies," map.

Sahlins, M. D., And E. R. Service (1960): Evolution and Culture. University of Michigan Press, Ann Arbor, MI.

Samatar, S. S. (1985): "Culture Areas and Smuggling: The Hausa and the Groundnut Trade across the Nigeria-Niger Boundary up to the 1970s," in Partitioned Africans: Ethnic Relations across Africa's International Boundaries 1884-1984, ed. by A. Asiwaju, pp. 156-195. C. Hurst Co. and University of Lagos Press, London, UK.

Schapera, I. (1967): Government and Politics in Tribal Societies. Schocken Books, New York, NY. 
- (1970): Tribal Innovators: Tswana Chiefs and Social Change, 1795-1940. Athlone Press, New York, NY.

Schultz, K. (2015): "Borders, Conflict, and Trade," Annual Review of Political Science, 18(1), 125-145.

Spear, T. (2003): "Neo-Traditionalism and the Limits of Invention in British Colonial Africa," Journal of African History, 44(1), 3-27.

Spolaore, E., and R. Wacziarg (2009): "The Diffusion of Development," Quarterly Journal of Economics, 124(2), 469-529.

(2013): "How Deep Are the Roots of Economic Development?," Journal of Economic Literature, $51(2), 325-369$.

Storeygard, A. (2015): "Farther on Down the Road: Transport Costs, Trade and Urban Growth in Sub-Saharan Africa," Review of Economic Studies, 83(3), 1263-1295.

Tabellini, G. (2008): "The Scope of Cooperation: Values and Incentives," Quarterly Journal of Economics, 129(3), 905-950.

(2010): "Culture and Institutions: Economic Development in the Regions of Europe," Journal of the European Economic Association, 8(4), 677-716.

TADEI, F. (2017): "Colonial Institutions, Prices to Producers, and Current African Development," working paper.

Teso, E. (2017): "The Long-Term Effect of Demographic Shocks on the Evolution of Gender Roles: Evidence from the Trans-Atlantic Slave Trade," Journal of the European Economic Association, forthcoming.

Thomson, A. (2010): An Introduction to African Politics. Routledge, London and New York.

Thornton, J. K. (1983): "Sexual Demography: The Impact of the Slave Trade on Family Structure," in Women and Slavery in Africa, ed. by C. Robertson, and M. Klein. University of Wisconsin Press, Madison, WI.

Tilly, C. (1985): "Warmaking and State Making as Organized Crime," in Bringing the State Back In, ed. by P. Evans, D. Rueschemeyer, and T. Skocpol. Cambridge University Press, Cambridge, UK.

Tischler, J. (2013): Light and Power for a Multiracial Nation The Kariba Dam Scheme in the Central African Federation. Palgrave MacMillan.

Touval, S. (1967): “The Organization of African Unity and African Borders," International Organization, $21(1), 102-127$. 
(TA. (1972): The Boundary Politics of Independent Africa, no. 1. Harvard University Press, Cambridge, MA.

van Beusekom, M., and D. L. Hogdson (2000): "Lessons Learned: Development Experiences in the Late Colonial PeriodâĂŹ," Journal of African History, 41(1), 29-130.

Vansina, J. (1978): The Children of Woot: A History of the Kuba Peoples. University of Wisconsin Press, Madison, WI.

(1990): Paths in the Rainforests. The University of Wisconsin Press.

Vogt, M., N.-C. Bormann, S. Ruegger, L.-E. Cederman, P. Hunziker, and L. Girardin (2015): "Integrating Data on Ethnicity, Geography, and Conflict: The Ethnic Power Relations Dataset Family," Journal of Conflict Resolution, 59(7), 1327-1342.

Voigtlander, N., And H.-J. Voth (2012): "Persecution Perpetuated: The Medieval Origins of AntiSemitic Violence in Nazi Germany," Quarterly Journal of Economics, 127(3), 1339-1392.

Waijenburg, M. V. (2018): "Financing the African Colonial State: The Revenue Imperative and Forced Labor," Journal of Economic History, 78(1), 40-81.

Waldinger, M. (2017): "The long-run effects of missionary orders in Mexico," Journal of Development Economics, 127, 355-375.

Wantchekon, L., and O. Garcia-Ponce (2014): "Critical Junctures: Independence Movements and Democracy in Africa," mimeo, Princeton University, Princeton, NJ.

Wantchekon, L., M. Klasnja, and N. Novta (2015): "Education and Human Capital Externalities: Evidence from Colonial Benin," Quarterly Journal of Economics, 130(2), 703-757.

Wesseling, H. L. (1996): Divide and Rule: The Partition of Africa, 1880-1914. Praeger, Amsterdam, NL.

Whatley, W. C. (2012): "The Transatlantic Slave Trade and the Evolution of Political Authority in West Africa," MPRA Paper 44932.

- (2018): "The Gun-Slave Hypothesis and the 18th century British Slave Trade," Explorations in Economic History, 67, 80-104.

Whatley, W. C., and R. Gillezeau (2011): "The Impact of the Transatlantic Slave Trade on Ethnic Stratification in Africa," American Economic Review Papers and Proceedings, 101(3), 571-576, MPRA Paper 44932 . 
Wietzke, F.-B. (2015): "Long-Term Consequences of Colonial Institutions and Human Capital Investments: Sub-National Evidence from Madagascar," World Development, 66(1), 293-307.

Wig, T. (2016): "Peace from the Past: Pre-colonial Political institutions and Civil Wars in Africa," Journal of Peace Research, 53(4), 509-524.

Wimmer, A., L.-E. Cederman, and B. Min (2009): "Ethnic Politics and Armed Conflict. A Configurational Analysis of a New Global Dataset," American Sociological Review, 74(2), 316-337.

Woodberry, R. D. (2012): "The Missionary Roots of Liberal Democracy," American Political Science Review, 106(2), 244-274.

Woodberry, R. D., And T. Shah (2004): "Christianity and Democracy: The Pioneering Protestants," Journal of Democracy, 15(2), 47-60.

Young, A. (2012): "The African Growth Miracle," Journal of Political Economy, 120(4), 696-739.

Young, C. (1994): The African Colonial State in Historical Perspective. Yale University Press, New Heaven, CT.

Zhang, Y., And S. Kibriya (2016): "The Impact of the Slave Trade on Current Civil Conflict in SubSaharan Africa," Working paper, Texas A\&M University, College Station, TX. 